\title{
Wilderness Experience in Rocky Mountain National Park 2002: Report to RMNP January 2004
}

Open File Report 03-445

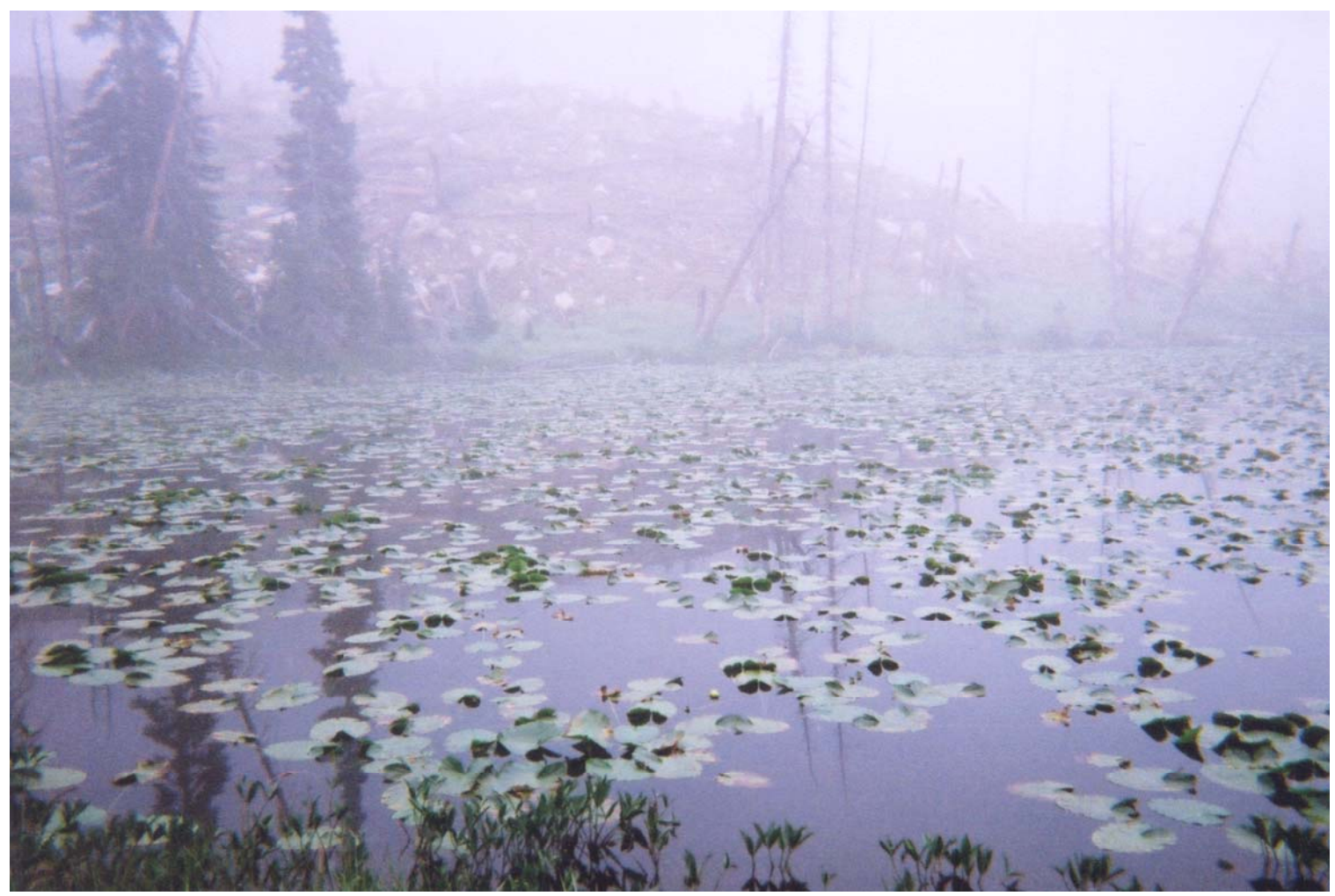

U.S. Department of the Interior U.S. Geological Survey

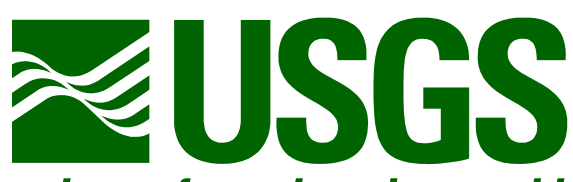

science for a changing world
Prepared in collaboration with Rocky Mountain National Park Wilderness/Research Program

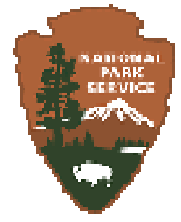




\title{
U.S. DEPARTMENT OF THE INTERIOR \\ U.S. GEOLOGICAL SURVEY
}

\section{Wilderness Experience in Rocky Mountain National Park 2002:}

\section{Report to RMNP}

\author{
by \\ Elke Schuster, S. Shea Johnson, and \\ Jonathan G. Taylor ${ }^{1}$ \\ Fort Collins Science Center \\ Policy Analysis \& Science Assistance Program \\ In collaboration with \\ Rocky Mountain National Park \\ Wilderness Program and \\ Continental Divide Research \\ Learning Center
}

January, 2004

USGS Open File Report 03-445

NPS Study \# ROMO 02034

This report has not been reviewed for conformity with the U.S. Geological Survey editorial standards. Any use of trade, product or firm names is for descriptive purposes and does not imply endorsement by the U.S. Government. 
Table of Contents

Page

List of Tables

List of Figures

Executive Summary __ iv

Introduction

The Background __ 1

The Goal__ 1

The Tools 2

The Camera and Photo-log__ 2

The Follow-up Survey __ 2

The Sample__ 3

Photo-log analysis

What was photographed and heard at Rocky Mountain N.P.?

Photo-log subjects__ 4

$\begin{array}{ll}\text { Photo-log sounds } & 10\end{array}$

Why were these photo subjects and sound-scapes important to Rocky Mountain

$\begin{array}{ll}\text { N.P. visitors' wilderness experiences? _— } & 16\end{array}$ $\begin{array}{ll}\text { Influence of Location __ } & 16\end{array}$

$\begin{array}{ll}\text { Conceptual Dimensions__ } & 19\end{array}$

$\begin{array}{ll}\text { Photo-subjects } & 20\end{array}$

Sound-Subjects 23

The Follow-up Survey _ 26

Important Places_— 26

$\begin{array}{ll}\text { Meaning of Wilderness Experience ___ } & 27\end{array}$

Complexity of Wilderness Experience __ 31

Effect of Changes in the Environment on Visitors' Wilderness Experience ___ 31 Effects of Sounds _ 33

$\begin{array}{ll}\text { Effect of Sights } & 34\end{array}$

$\begin{array}{ll}\text { Verbal Descriptions _ } & 36\end{array}$

$\begin{array}{ll}\text { Verbal Descriptions of Sounds__ } & 37\end{array}$

Verbal Descriptions of Sights__ $\quad 40$

The Respondents__ 43

Discussion _ـ 45

What have we learned about wilderness experiences in RMNP? ___ 45

What does this mean for Park management? ___ 46

References

Appendix A - The Photo-log \& Follow-up Survey

Appendix B - The Sampling Plan

Appendix C - Photo-log Results

Appendix D - Follow-up Survey Results 


\section{List of Tables}

Table

Page

1. Count totals and percentages for natural subject photos for $n=254$ respondents.

2. Count totals and percentages for human subject photos for $n=254$ respondents.

3. Percent of positive vs. negative effects on wilderness experience for natural subject only photos.

4. Percent of positive vs. negative effects on wilderness experience for human subject only photos.

5. Count totals and percentages for nature made sounds for $n=254$ respondents.

6. Count totals and percentages for human-made sounds for $n=254$ respondents.

7. Percent of positive vs. negative effects on wilderness experience for natural sounds only.

8. Percent of positive vs. negative effects on wilderness experience for human sounds only.

9. Comparison of percentages of photo subjects and type of sounds by region surveyed within RMNP.

10. Comparison of percentages of photo subjects by region surveyed within RMNP.

11. Comparison of percentages of sound reports by region surveyed within RMNP.

12. Percent of statements given by respondents describing various photo subject effects on wilderness experiences.

13. Percent of statements given by respondents describing various sound effects on wilderness experiences.

14. Most important photographed place to wilderness experience.

15. Most important reason for visiting RMNP by user group.

16. Important wilderness experience themes.

17. The effect of sounds on visitors' wilderness experience in RMNP.

18. The effect of sights on visitors' wilderness experience in RMNP.

19. How sounds alter visitors' wilderness experience (Trail scenario).

20. How sounds alter visitors' wilderness experience (Scenic Vista scenario).

21. How sights alter visitors' wilderness experience (Open Area scenario).

22. How sights alter visitors' wilderness experience (Water scenario).

23. Follow-up survey experience variables. 


\section{List of Figures}

Figure

Page

1. Percentage of human or human-made only vs. natural only photo subjects. 5

2. How does the subject of this photo affect your wilderness experience?

3. Human subject vs. natural subject: How does the subject of this photo affect your wilderness experience?

4. Popular nature subject photos and explanations of effect on wilderness experiences.

5. Popular human subject photos and explanations of effect on wilderness experience.

6. Human-made vs. natural sound: How do these sounds affect your wilderness experience?

7. How do the sounds you are hearing affect your wilderness experience?

8. Human-made vs. natural sound: How do these sounds affect your wilderness experience?

9. Example explanations of nature sound subjects.

10. Example explanations of human sound subjects.

11. When you visit RMNP, so you consider yourself to be in wilderness?

12. Trail and Open Area scenarios.

13. Scenic Vista and Water scenarios. 32

14. Effect of cell phones and sound of other hikers. 34

15. Effect of bull elk walking into sight. 


\section{Executive Summary}

Approximately 250,000 acres of backcountry in Rocky Mountain National Park (RMNP or the Park) may be designated as wilderness use areas in the coming years. Currently, over 3 million people visit RMNP each year; many drive through the park on Trail Ridge Road, camp in designated campgrounds, or hike in front-country areas. However, visitors also report much use of backcountry areas that are not easily accessible by roads or trails. Use of the backcountry is growing at RMNP and is accompanied by changing visitor expectations and preferences for wilderness management. For these reasons it is of great importance for the Park to periodically assess what types of environments and conditions wilderness users seek, to help them facilitate a quality wilderness experience.

To assist in this effort, the Political Analysis and Science Assistance [PASA] program / Fort Collins Science Center / U.S. Geological Survey, in close collaboration with personnel and volunteers from RMNP and in cooperation with the Natural Resource Recreation and Tourism [NRRT] Department at CSU, and launched a research effort in the summer of 2002 to investigate visitor numbers, wilderness experiences, and management preferences in the Park.

Specifically, the purposes of the research reported here are: (1) To determine what constitutes a wilderness experience; (2) To identify important places, visual features, and sounds essential to a quality wilderness experience and; (3) To determine what aspects may detract from wilderness experience in RMNP. Thus, answers to these questions should provide insight for Park managers about visitors' expectations for wilderness recreation and the conditions they seek for quality wilderness experiences. Ultimately, this information can be used to support wilderness management decisions within RMNP.

The social science technique of Visitor Employed Photography [VEP] was used to obtain information from visitors about wilderness experiences. Visitors were selected at random from Park-designated wilderness trails, in proportion to their use, and asked to participate in the survey. Respondents were given single-use, 10-exposure cameras and photo-log diaries to record experiences. A total of 293 cameras were distributed, with a response rate of $87 \%$. Following the development of the photos, a copy of the photos, two pertinent pages from the photo-log, and a follow-up survey were mailed to respondents. Fifty six percent of the follow-up surveys were returned. Findings from the two surveys were analyzed and compared. The key findings for this study are highlighted as follows:

\section{What was photographed?}

o Respondents took photos of natural subjects only, human or human-made subjects only or combinations of both human and natural subjects. Natural subject only photos accounted for more photographed subjects than any other category (70\%).

o Approximately $80 \%$ of all photos included a natural feature. Running water features (i.e., rivers, creeks, streams) were the most photographed natural feature, followed by trees then the category of mountains, peaks or glaciers.

o Collectively, photos of people and of hiking trails constituted over half of all human or human-made subject photos (57\%). 


\section{What was the effect of these subjects on wilderness experiences?}

o Most photo subjects had a positive effect on wilderness experience (87\%).

o Cross comparisons showed that almost all of the natural-subject photos taken (93\%) had a positive effect on wilderness experiences, whereas, only $66 \%$ of human-subject photos had such an effect on experiences.

\section{What sounds were being heard?}

o Respondents listed, in the photo-logs, sounds of natural origin, non-mechanized or mechanized human sounds, or a combination of both. A majority of sounds reported were of natural origin only $(77 \%)$.

o Sounds of water were reported most often (39\%) compared to other natural sounds, followed by sounds of wildlife and wind.

o Sounds of human voices were reported more often than any other human origin sound (46\%). Cars and motorcycles were the most reported mechanized human sound with airplane noise a close second.

\section{What was the effect of these sounds on wilderness experience?}

0 As with photo subjects, most sounds had a positive effect on wilderness experiences (81\%).

o Cross comparisons of human origin and natural origin sounds with effect on wilderness experience showed that $93 \%$ of natural sounds had positive effects, whereas, only $34 \%$ of human sounds had positive effects on experiences.

\section{Why did sounds \& subjects affect wilderness experiences?}

o Human-made subjects were listed as positive for reasons such as the facilitation of wilderness experiences, increasing ease of access to the Park, or as an indication of the National Park Service conserving lands. Human subjects had negative effects if they were an indication of environmental degradation, horse presence on trails, or interference with use of the Park.

o Human voices were positive because of the enjoyment of hearing others enjoy nature and the Park, or were a reminder of the importance of sharing wilderness experiences with others. Voices were thought to be negative when they implied the Park was too crowded. Mechanized noises such as planes or cars were a reminder of everyday life, stress, and civilization. These latter noises were thought to be out of place in wilderness.

\section{What were the most important places to respondents?}

o Lakes and ponds were the most chosen "peak" picture by respondents, followed by mountains or glaciers then scenic vistas.

\section{How did respondents define a wilderness experience?}

o When asked to describe, in their own words, what the experience of being in the wilderness at RMNP means to them, respondents' answers revealed a number of emergent themes. "Aesthetics" was the most often mentioned theme, followed by "physical escape", then "solitude". A total of eleven researcher-defined themes were identified for this measure. 
o The meaning of wilderness experience is not a simple, straight-forward construct for Park visitors, but a complex one that includes multiple reasons for a wilderness experience being an important component to recreation at RMNP.

o The most important reason for visiting RMNP, for these visitors, was to enjoy the backcountry or wilderness itself. There was no difference between day hikers or overnight users on this measure.

o A majority of day hikers (68\%) and overnight users (65\%) felt that "being in wilderness" depended on where they were in the Park.

\section{How did changes in sights and sounds affect wilderness experiences?}

0 When asked about changes in sounds, respondents reported that hearing birds sing was the most enhancing sound, followed by thunder from an approaching storm. Hearing a person on their cell phone was the most detracting sound, followed by a jet flying overhead.

o Seeing an elk was greatly enhancing, however, this experience was altered to only neutral if the elk was wearing a radio collar. Seeing trash was the most detracting, followed by seeing a family feed a chipmunk.

o Explanations for the reasons why these sights and sounds were enhancing or detracting from a wilderness experience were similar to the conceptual dimensions that emerged from respondents' previous explanations for subject and sounds' effects on wilderness experiences in the photo-log exercise. In general, natural sights and sounds were perceived to be enhancing to the experience, whereas, non-natural or human-origin sights and sounds detracted, more or less, from the beauty and solitude of the wilderness area.

\section{Who were the respondents?}

o Most respondents had visited the backcountry and front country of RMNP many times before this trip. The average number of trips to the backcountry was 10.2 , and to the front country, 10.7.

o In the past year most respondents had visited the backcountry 3.8 times, and the front country 2.8 times.

o Out of the respondents who answered the follow-up survey, 59\% were male, between the ages of 26 and 55 (67\%), well educated with $48 \%$ having graduate or professional degrees, and 23\% reported annual incomes of over $\$ 100,000$. 


\section{Introduction}

\section{The Background}

Visitation to Rocky Mountain National Park [RMNP or the Park] is large and increasing. Total visitation to RMNP topped 3 million in 1994, and was over 3.1 million in 2002, ranking $5^{\text {th }}$ in visitation among the country's National Parks. Rocky Mountain National Park is located close to the Colorado Front Range area and draws visitors from a rapidly expanding regional resident population, in addition to the long-standing national and international flows of visitors to the Park. Although many tourists drive through the Park on Trail Ridge Road, only stopping occasionally at scenic overlooks, and many come in to camp in designated campgrounds or to day-hike on short trails; $95 \%$ of the Park land area is backcountry, not accessible by road or quickly accessible on highly maintained trails. Nearly 3,000 acres of the Park backcountry are officially Wilderness, while close to 250 thousand acres have been recommended to be designated as wilderness. Visitors report multiple visits to the Park; many of which are to wilderness areas (see Table 23).

With backcountry use burgeoning, and with the composition of the wilderness use population changing, it is necessary for the Park to assess, periodically, the kinds of experience wilderness users are seeking and the environments and conditions that contribute to the quality of those experiences. It has been recognized for over 30 years (Peterson \& Lime, 1973) that the experience expectations of resource management staff cannot be used as surrogate for those of the visiting public. Expectations vary greatly, and often management hears only the voices of vociferous minorities, making it difficult to understand the full spectrum of visitor population needs for quality experience. Discerning the experience needs of the wilderness-use population of the Park is important for many reasons, not the least of which being that wilderness users report more willingness to support Park conservation programs than any other user group (Taylor et al., 1995, Taylor, Sexton, and Czarnowski, 1995).

\section{The Goal}

How do visitors to Rocky Mountain National Park define what constitutes a wilderness experience? What are the important places, features, and sounds essential to their quality of wilderness experience and why? And which aspects enhance or detract from their wilderness experience? The goal of this study was to answer these questions in order to provide RMNP managers with a deeper understanding of what visitors value in wilderness and what kind of experience they are looking for. This information, in turn, has the potential to help planners and managers to support specific management decisions concerning wilderness use.

The research was conducted in the summer of 2002 by the Political Analysis and Science Assistance [PASA] Science Program / Fort Collins Science Center / U.S. Geological Survey; by RMNP personnel, especially wilderness rangers and volunteers; and in collaboration with the Natural Resource Recreation and Tourism [NRRT] Department at Colorado State University [CSU]. 


\section{The Tools}

This study used the same experience-recording technique applied before in RMNP in 1993 to determine the social value of water resources: Visitor Employed Photography [VEP]. A completely new aspect of this research was to include a measurement of how particular sounds affect the quality of wilderness experience for visitors. Sounds can have a tremendous positive or negative effect on wilderness experiences, especially in remote locations. Frequent aircraft overflights in Rocky Mountain National Park are one of the reasons why managers are concerned about the level of disruption of the wilderness experience by commercial jets and the sounds associated with them.

The two fundamental research instruments used to collect information from Park visitors about their wilderness experience were: 1) a 35-mm disposable camera and photo-log booklet, and 2) a follow-up mail-back survey.

\section{The Camera and Photo-log}

Park visitors were selected at random along specified trails and at trailheads identified by Park staff. Distribution was made proportional to approximate trail-use densities, based on Wilderness use records and experience, and distributed over weekends and week-days to capture a broad representation of Park wilderness visitation. Randomization was done by selecting time intervals between intercepts, e.g., "wait 18 minutes and then speak to the next hiker going west (into the Wilderness) on the trail."

Visitors were very briefly interviewed to determine their willingness to participate in the camera/photo-log study. Those who agreed were given single-use, 10 -exposure, $35-\mathrm{mm}$ cameras and instructed to photograph those elements or locations in the landscape that have the strongest effects on the quality of their wilderness experience. For each photograph, participants were asked to record in a photo-booklet: 1) what they were taking a picture of, 2) where the photograph subject ${ }^{\mathrm{a}}$ was located, 3 ) whether the effect of the photo subject was positive, negative or both, 4) why the subject was important to their experience, 5) what sounds they were aware of at this particular location, 6) whether the effect of the sounds were positive, negative or both, and 7) how these sounds affected their wilderness experience (see Appendix A: Photo-log).

\section{The Follow-up Survey}

A complete set of photographs was sent to each respondent who completed the camera exercise together with copies of two of their photo-log pages and a follow-up survey. There were two versions of the follow-up survey. Both versions contained standard demographic questions (age, education, etc.), questions intended to elicit further information about quality of wilderness experience in RMNP, scales on visitors' feelings and emotions tailored specifically to their current trip as well as to environmental issues in general. Both survey versions included a set of hypothetical scenarios that were inserted into the respondents' wilderness experiences, using their own photographs as the background setting. The scenarios differed between survey versions to allow for a greater variety of reactions to changes in the environment (see Appendix A: Follow-up Survey).

a "subject" in this report refers to the object photographed or reported, not the respondent. 


\section{The Sample}

The sampling distribution for the cameras was worked out in close cooperation with the wilderness managers at RMNP. A total of 300 people were included in the sample for the camera exercise; 200 cameras were to be distributed to day hikers and 100 cameras to backcountry overnight users. The actual distribution came very close to this plan, with 293 total cameras handed out to visitors of the Park. The two groups of park users were defined as follows: day hikers generally take intermediate-level day hikes on the Park's developed trail system. Hikers included rock climbers at Twin Owls trailhead, headed towards Lumpy Ridge. Overnight users are required to obtain backcountry use permits for backpacking farther into the less developed areas of the Park.

The month of July 2002 was chosen for distribution of all cameras. Day hiker and overnight user sampling at the trailheads was divided proportionally between $60 \%$ weekend hikers and $40 \%$ weekday hikers to mimic actual use patterns. Four general use areas, including 21 specific trailheads, were identified in close collaboration with wilderness rangers. The locations were based upon estimates of relative day and overnight use in the Park. Two additional trailheads were included later on during the study to reflect more accurate wilderness use (see Appendix B: Sampling plan). All day hiker and overnight user sampling was to take place at trailheads in the morning to capture hikers on their way out into wilderness areas. To randomize the sampling procedure, every "nth" (randomly chosen number) visitor was intercepted. A restriction was placed on the number of cameras to be distributed (no more than four cameras per day at the same location for the same user group) and the number of days for camera distribution (single day distribution of all cameras for the same user group for the same location was avoided). Trained Park volunteers handed the cameras and photo-logs to visitors at trailheads. Respondents had the option of leaving their cameras and photo-logs in drop-off receptacles located at each Park exit, certain trailheads, and Visitor Centers or of mailing them in.

Of the 293 visitors who agreed to participate in the study, 254 (87\%) completed and returned the cameras and photo-logs. One hundred and forty of 249 respondents returned completed followup surveys for a response rate of $56 \%$. The relatively low response rate for the mail-back survey, especially compared with the results of the 1993 survey, can probably be explained by two factors: 1) the disposable cameras were made from recycled shells containing new film. Visitors reported that some of the cameras did not work at all or broke during their trip. Also, an estimated 20 percent of the cameras allowed light to get inside the shell, thereby reducing the quality of the film. Respondents looking forward to their set of photographs might well have been disappointed with the quality of the pictures and therefore less willing to complete the follow-up survey, and 2) most backcountry overnight users seem to start their trip in the afternoon rather than the morning, therefore volunteers had problems handing out the overnight user cameras at the trailheads in the morning. Leftover cameras had to be re-distributed several times along assigned trails, or finally handed out at the backcountry permit office. The last cameras were handed out in September 2002, extending the return date for mail-back surveys well into November and December. This may have prevented some respondents, busy with holiday preparations, from returning the surveys. 


\section{Photo-log analysis}

\section{What was photographed and heard at Rocky Mountain N.P.?}

Respondents took 10 photos and recorded written photo-log entries as participants in the study. The photo-log asked respondents to describe what they were photographing, where it was located, how the photo subject affected their wilderness experience, what sounds they were aware of while taking the photo and how these sounds also affected their wilderness experience. In total there were 2540 possible photo \& sound records for this study $(\mathrm{n}=254$ respondents each recording 10 photos each). A total of 288 photos were either not recorded by respondents or were not taken, therefore 2252 photos \& photo-log entries are used in this analysis. Frequency counts for photo type and sound occurrences were calculated and cross comparisons, of effect on wilderness experience with photo and sound type, were made to gain a better understanding of what factors positively or negatively impact typical visitor wilderness experiences.

\section{Photo-log subjects}

Respondents took photos of natural subjects (i.e., lakes, mountains, wildlife) humans or humanmade subjects (i.e., family, hikers, children, trails, park service buildings), or a combination of natural and human or human-made subjects. In general, respondents took more natural subject only photos $(70 \%)$ than human subject only photos (Figure 1 ).

A detailed listing of specific photo subject categories with counts and percents is given in the appendix (Table C-1). Table 1 shows the aggregate counts and percentages for natural photo subjects based on the more prevalent categories shown in Table C-1 in the appendix. Running water features comprised $23 \%$ of natural subject aggregate photos and still water features $13 \%$, which demonstrates that water was photographed in over a third of all natural subject photos. Photo subjects of trees or forests were also popular and made up 17\% of natural subject aggregate photos.

Table 2 shows the aggregate counts and percentages for human subject photos based on common categories shown in the appendix (Table C-2). Collectively, photos of people and of hiking trails consisted of over half of all human or human-made subject photos (57\%). Human-made structures comprised $37 \%$ of the aggregate count of human-made photos. Lastly, $6 \%$ of human subject photos revealed evidence of horse presence on trails.

Most photo subjects had a positive effect on wilderness experience (87\%), only small portions of photo subjects had a negative or both positive and negative effects on the respondent (Figure 2). In general, respondents who reported "both positive and negative" effects explained their reasoning in the space provided. For example, a respondent may have said "both positive and negative" to a photo of a bridge with the following explanation: "Positive because the bridge helped us cross the river, negative since it is a man-made structure intruding on nature." To better understand respondents' feelings on photo subjects that produced both effects, a conceptually deeper analysis was completed and is presented in the latter portion of this section. 
Figure 1. Percentage of human or human-made only vs. natural only photo subjects $(\mathrm{n}=2252)$.

$21 \%$ of all photos were of human or human-made subjects only $(\mathrm{n}=471)$

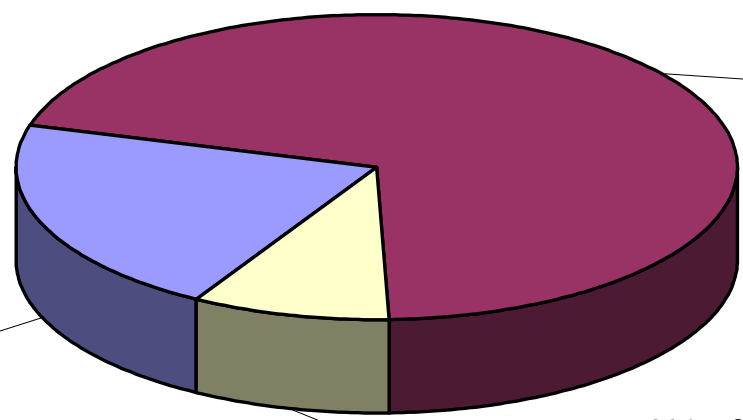
$70 \%$ of all photos were of natural subjects only $(\mathrm{n}=1573)$

$$
\begin{gathered}
9 \% \text { of photos } \\
\text { consisted of both } \\
\text { human \& natural } \\
\text { subjects } \\
(\mathrm{n}=208)
\end{gathered}
$$

Table 1. Count totals and percentages for natural subject photos for $n=254$ respondents. ${ }^{1}$

\begin{tabular}{lcc}
\hline Nature subject & $\begin{array}{c}\text { Number of } \\
\text { aggregate photos } \\
\text { that included this } \\
\text { subject }\end{array}$ & $\begin{array}{c}\text { Percent of } \\
\text { natural subject } \\
\text { aggregate } \\
\text { photographs }\end{array}$ \\
\hline Running Water (Rivers, Creeks, Streams) & 554 & 23 \\
Trees & 382 & 17 \\
Mountains, Peaks or Glaciers & 338 & 15 \\
Still Water (Lakes or Ponds) & 298 & 13 \\
Wildlife & 241 & 8 \\
Rocks/Cliffs/Boulders & 199 & 7 \\
Meadows, Valleys or Open Spaces (including vistas) & 180 & 6 \\
Wildflowers & 143 & 1 \\
\hline Forest Fire or Burn Area & 31 & 10 \\
\hline
\end{tabular}

1 Counts and percents are generalized aggregates of specific photo subject categories.

See Appendix $\mathrm{C}$ for detailed listing of counts and percentages. 
Table 2. Count totals and percentages for human subject photos for $\mathrm{n}=254$ respondents. ${ }^{1}$

\begin{tabular}{lcc}
\hline Human or human-made subject & $\begin{array}{c}\text { Number of } \\
\text { aggregate photos } \\
\text { that included this } \\
\text { subject }\end{array}$ & $\begin{array}{c}\text { Percent of } \\
\text { human subject } \\
\text { aggregate } \\
\text { photographs }\end{array}$ \\
\hline People & 224 & 34 \\
Trails & 152 & 23 \\
Campsites & 73 & 11 \\
Trail Signs \& Markers & 67 & 10 \\
Buildings & 60 & 9 \\
Bridges & 46 & 7 \\
Horses \& Horse Droppings (including pack animals) & 38 & 6 \\
\hline
\end{tabular}

1 Counts and percents are generalized aggregates of specific photo categories.

See Appendix $\mathrm{C}$ for detailed listing of counts and percentages.

Figure 2. How does the subject of this photo affect your

$6 \%$ of all photos reflected both a positive \& negative wilderness experience? $87 \%$ of all photos reflected a positive affect on the wilderness affect on

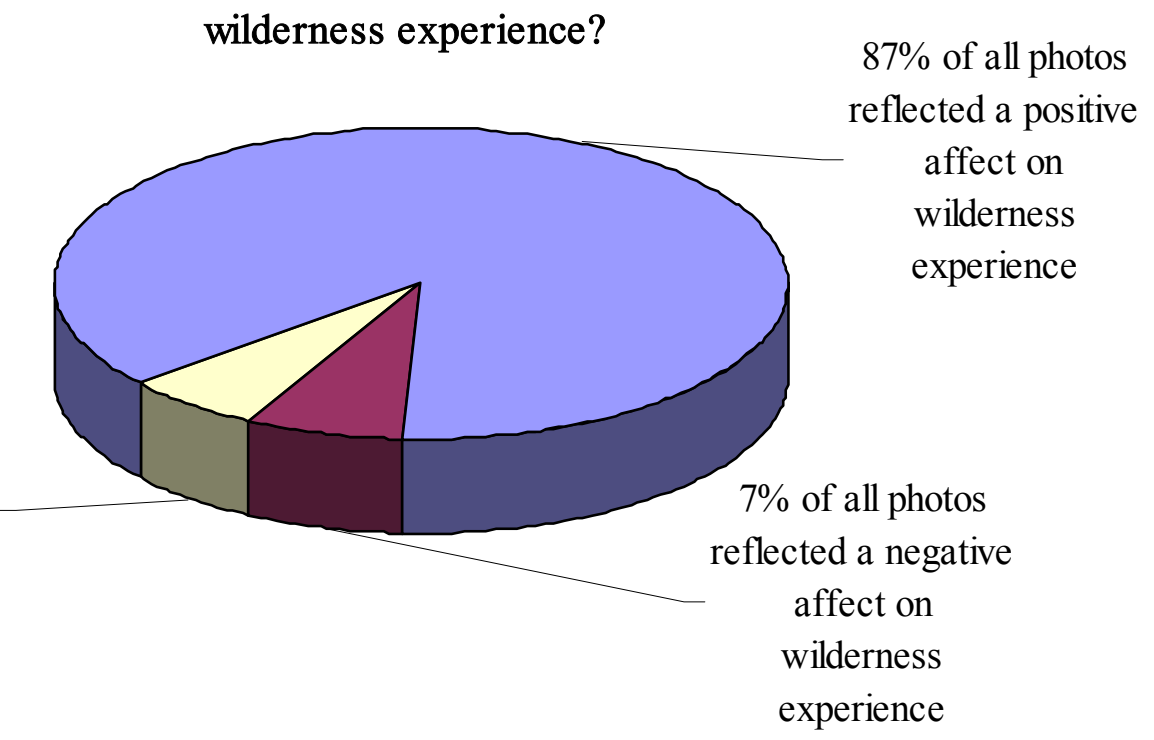
experience 
A cross comparison of human or human-made and natural subject photos with affect ${ }^{\mathrm{b}}$ on wilderness experience shows that almost all of the natural subject photos taken $(93 \%)$ had a singularly positive effect on respondents' wilderness experiences, whereas, only $66 \%$ of human subject photos taken had such a positive effect on wilderness experiences (Figure 3). In general, we can conclude that there is a statistically significant difference among the three types of photos (e.g., natural, human origin and photos containing both natural and human subjects) on respondents' wilderness experiences.

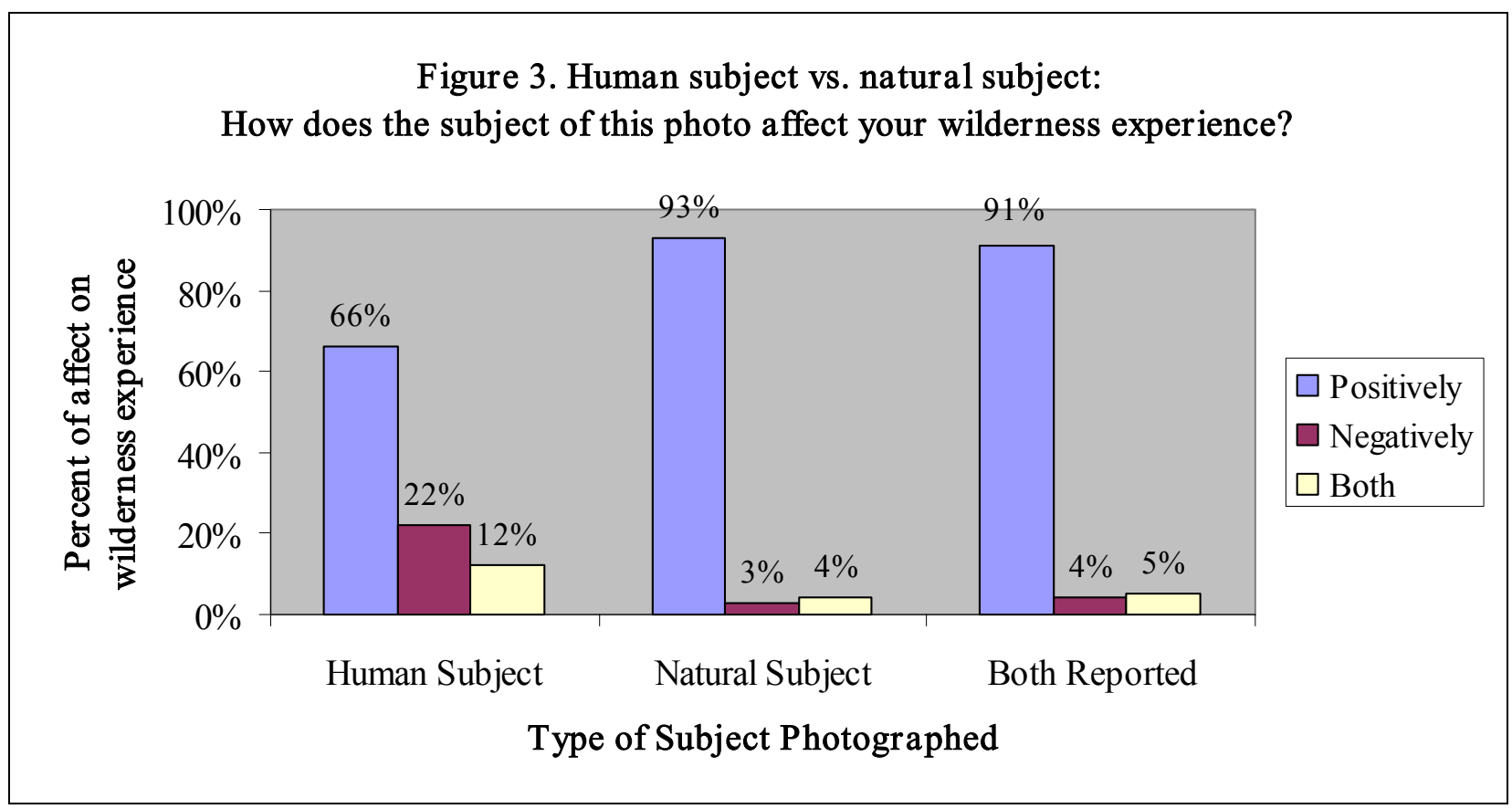

It was of interest to compare the specific photo subjects with affect on wilderness experience in order to determine if different patterns emerged depending on specific type of photo (e.g., For human subject photos, does a photo of a privy have a different effect on wilderness experience than a photo of a trail?) Comparisons were made for those photo subjects that occurred in the photo-logs across fifteen photo-logs, and were described by the respondents as the primary subject of the photo. Cross-comparisons were not made for photos described by the respondents as combination subjects (e.g., a privy and a trail) since it could not be determined which subject described had the positive or negative effect on the experience at this level of investigation. Findings from a more in-depth analysis, which addressed these issues, are discussed later in this section.

Overall, respondents' wilderness experiences were differentially affected by natural versus human or human-made photo subjects. Although a majority of natural subjects affected wilderness experiences positively, forest fire and burn areas revealed a greater percentage of

b "Affect" is used frequently, in this report, in differentiating between cognitive (thought driven) and affective (emotion driven) responses. 
negative effects than other natural subject categories. Human subject photos caused both positive and negative effects on experience.

Table 3 shows the percent of positive and negative effects on wilderness experience by natural photo subject type. Parallel to the general findings, specific, natural photo- subjects affected respondents' wilderness experiences in a positive manner (See Figure 4 for sample photos and respondent comments). However, a greater percentage of negative effects are reported for forest fire or burn areas photos ( $29 \%$ positive, $29 \%$ negative and $42 \%$ both positive and negative).

Table 3. Percent of positive vs. negative effects on wilderness experience for natural subject only photos.

\begin{tabular}{lcccc}
\hline $\begin{array}{l}\text { Most photographed } \\
\text { natural subjects }\end{array}$ & $\mathrm{n}^{1}$ & \% positive & \% negative & \% both \\
\hline Wildlife & 172 & 92 & 1 & 7 \\
Mountains or Glaciers & 167 & 95 & 3 & 2 \\
Lake or Pond & 164 & 93 & 1 & 6 \\
Waterfall & 124 & 98 & 1 & 1 \\
Trees & 100 & 84 & 10 & 6 \\
River, Creek, Stream & 95 & 97 & 0 & 3 \\
Rocks, Cliffs, Boulders & 86 & 95 & 3 & 2 \\
Wildflowers & 75 & 99 & 0 & 1 \\
Vista or Scenic View & 58 & 98 & 2 & 0 \\
Mountain \& Lake & 56 & 96 & 2 & 2 \\
Meadows or Valleys & 51 & 96 & 0 & 4 \\
Forest Fire or Burn Area & 24 & 29 & 29 & 42 \\
\hline
\end{tabular}

1 The value of $n$ for this table represents the number of photos of only the particular nature subject listed where respondents also provided an evaluation of the subject's effect on wilderness experience. These values for $n$ do not represent the total number of photos taken of these subjects for the entire data set.

Table 4 shows the percent of positive and negative effects on wilderness experience by human or human-made photo subject. Results of the cross-comparison for human subject photos with effect on wilderness experience were more varied than for natural subject comparisons (See Figure 5 for sample photos and respondent comments). Human photo subjects that had the most accounts of positive effects on wilderness experience were photos of people, trails and campsites. Photos of horse droppings had a profound negative effect on respondents' experiences ( $91 \%$ negative). While photos of NPS buildings had mixed effects on experiences (58\% positive, $26 \%$ negative, $16 \%$ both positive and negative). 
Figure 4. Popular nature subject photos and explanations of effect on wilderness experiences.

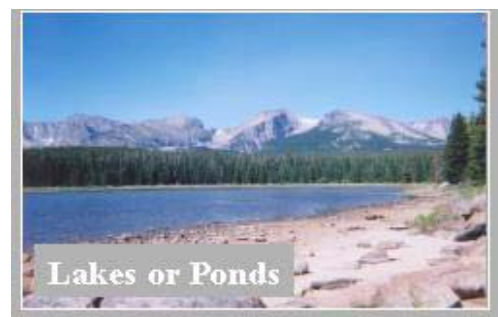

"This is one of my favorite places on earth The view is exciting no matter how many times I've been here.'

Positive effect on wilderness experience

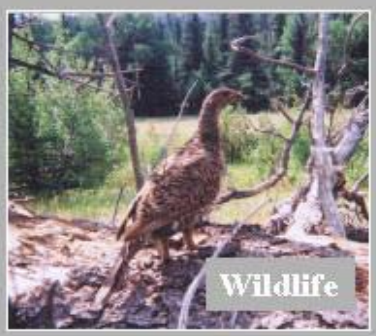

"It's nice to see animals in their natural habitat.

Positive effect on wildemess experience

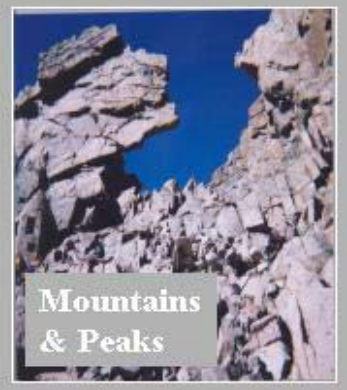

Rivers or Streams

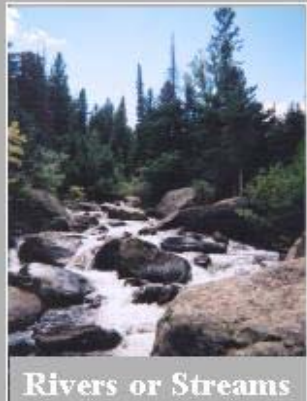

New trees growing among burnt old ones.

Shows vastness \& distinct color change." Both positive \& negative effect on wildemess experience

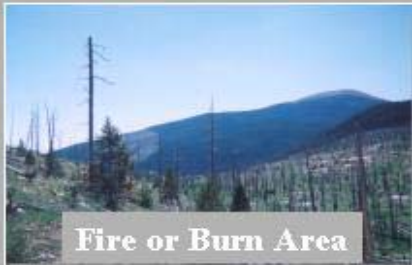

Pinnacles \& towers: Aesthetics, are a big reason to hike or climb. Pesitive effect on wildermess experience

Figure 5. Popular human subject photos and explanations of effect on wilderness experience.

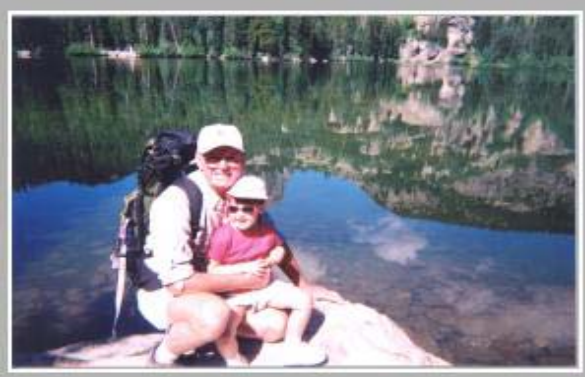

\section{Examples of "hromon" subjects photos:}

"Loved ones on a rock overlooking the lake"

Positive effect on wilderness experience
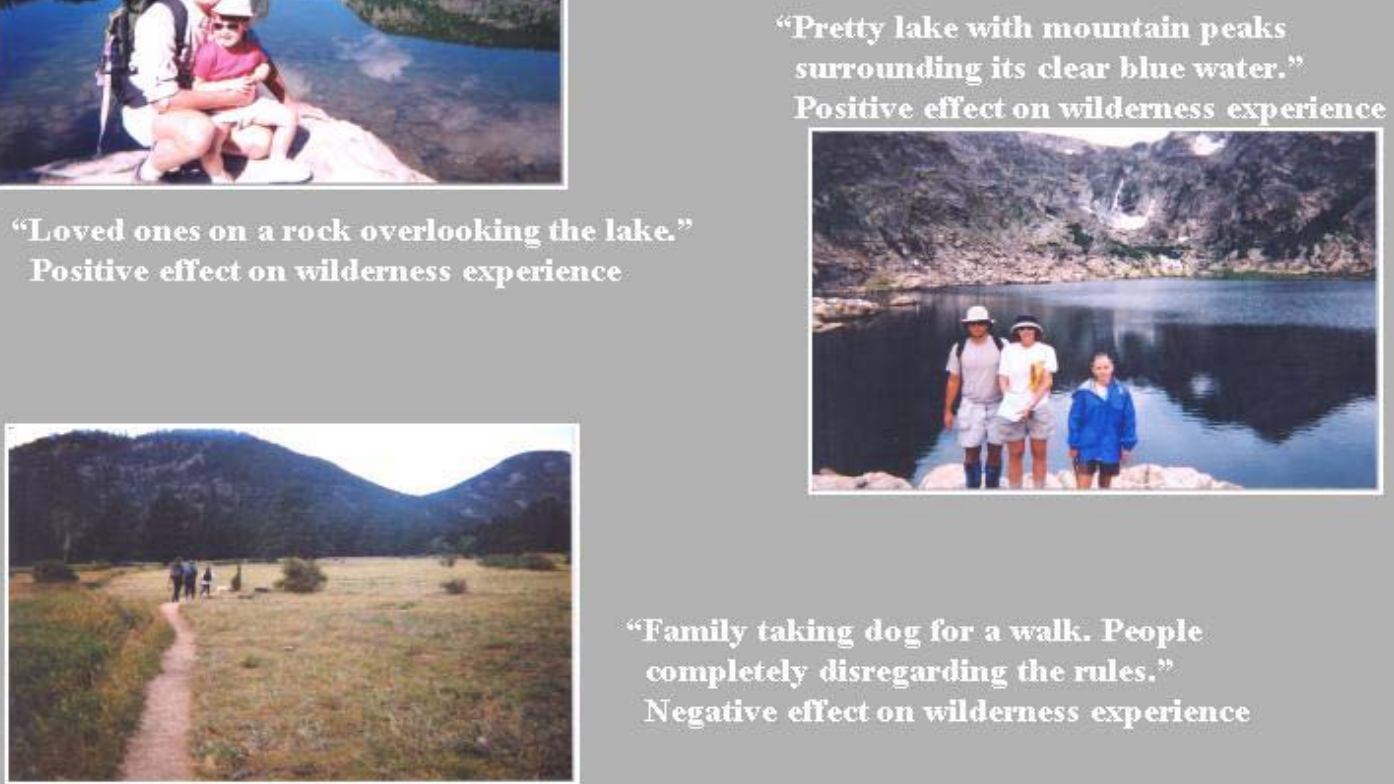

"Family taking dog for a walk. People completely disregarding the rules." Negative effect on wilderness experience 
Table 4. Percent of positive vs. negative effects on wilderness experience for human subject only photos.

\begin{tabular}{lcccc}
\hline $\begin{array}{l}\text { Most photographed } \\
\text { human subjects }\end{array}$ & $\mathrm{n}^{2}$ & \% positive & \% negative & \% both \\
\hline Trail & 77 & 78 & 10 & 12 \\
People/Socializing & 55 & 89 & 7 & 4 \\
Trail Markers/Signs & 51 & 71 & 12 & 17 \\
Campsite & 44 & 77 & 7 & 16 \\
Horse Droppings & 32 & 0 & 91 & 9 \\
Park Service Buildings & 31 & 58 & 26 & 16 \\
People and Trail & 16 & 100 & 0 & 0 \\
People and Campsite & 15 & 80 & 13 & 7 \\
\hline
\end{tabular}

1 Photos of trash \& fishing were among the top 10 human subjects most photographed, however, a comparison to +/- affect was not reported due to a small number of "trash only" or "fishing only" photos $(\mathrm{n}<15)$.

2 The value of $n$ for this table represents the number of photos of only the particular human subject listed where respondents also provided an evaluation of the subject's effect on wilderness experience. These values for $n$ do not represent the total number of photos taken of these subjects for the entire data set.

\section{Photo-log sounds}

Respondents reported sounds of natural origin (i.e., water, wind, birds), non-mechanized (i.e., voices, footsteps, children) or mechanized human sounds (i.e., traffic, airplanes, construction noise), or a combination of natural and human origin sounds. A majority of sounds reported (77\%) were of natural origin only (Figure 6). Parallel to photo-log findings for natural subject only photos, natural sounds only were most frequently reported by respondents.

A detailed listing of specific sound report categories with counts and percents is given in the appendix (Table C-3). Table 5 shows the aggregate counts and percentages for natural sound reports based on the more prevalent categories shown in Table C-3 in the appendix. More respondents reported sounds of water than any other natural sound (39\%). Wildlife including insects roughly accounted for a third of natural sound reports and wind and weather slightly more than $20 \%$.

Similarly, Table 6 provides aggregate counts of human origin sounds (See Table C-4 in appendix for greater detail). Sounds of human voices were reported more often by respondents than any other non-mechanized human origin sound ( $46 \%$ of all human-made sounds), whereas, cars \& motorcycles the most reported mechanized human origin sound with airplane noise a close second (Table 6). 


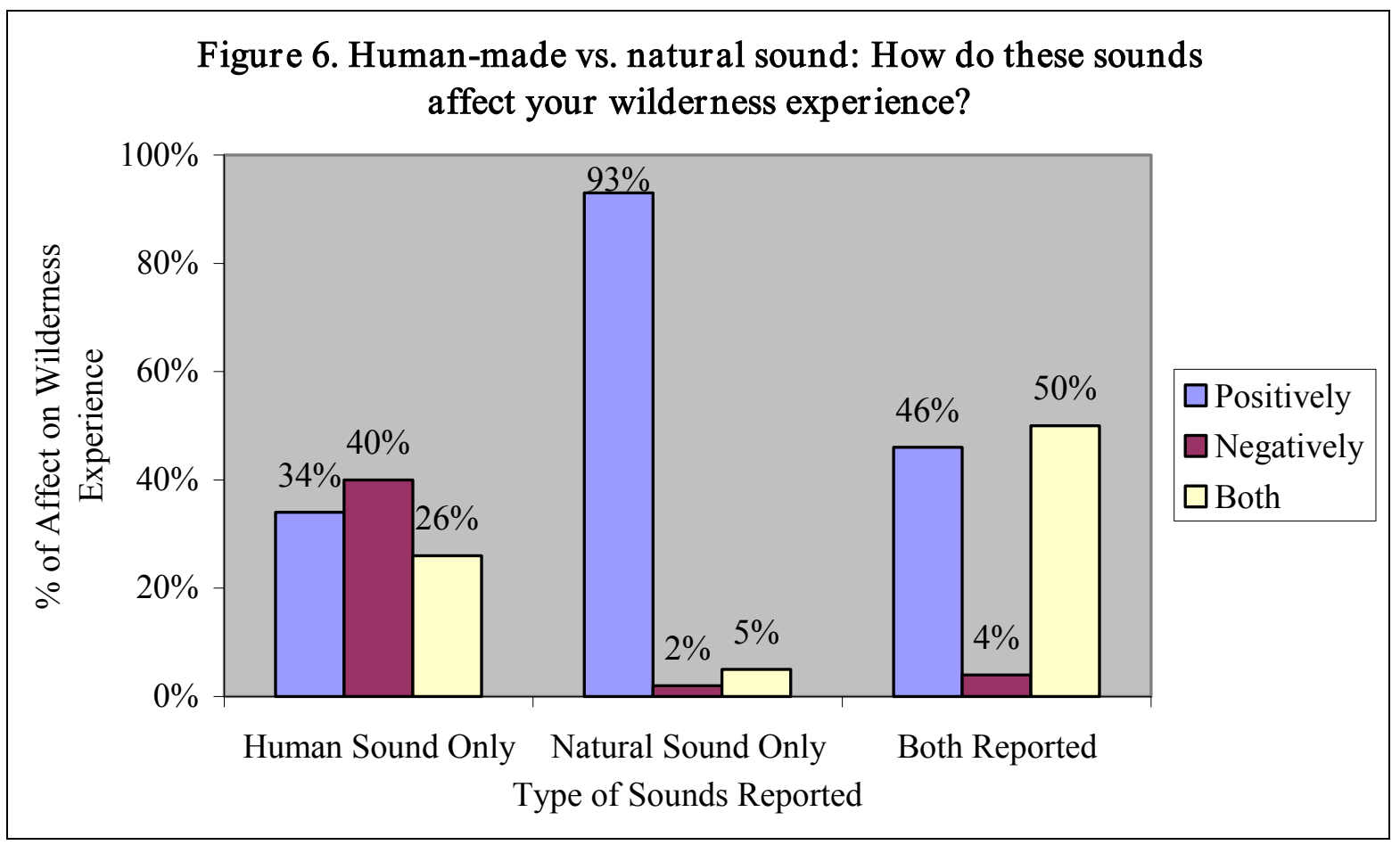

Table 5. Count totals and percentages for nature made sounds for $\mathrm{n}=254$ respondents. ${ }^{1}$

\begin{tabular}{lcc}
\hline Nature sound & $\begin{array}{c}\text { Number of } \\
\text { aggregate reports } \\
\text { that included this } \\
\text { sound type }\end{array}$ & $\begin{array}{c}\text { Percent of } \\
\text { aggregate } \\
\text { natural sound } \\
\text { reports }\end{array}$ \\
\hline Water & 861 & 39 \\
Wildlife (including insects) & 718 & 32 \\
Wind & 466 & 21 \\
Quiet or Silence & 134 & 8 \\
Weather (including thunder, rain, hail but not & 46 & 2 \\
wind) & & \\
\hline
\end{tabular}

1 Counts and percents are generalized aggregates of specific reported sound categories. See Appendix $\mathrm{C}$ for detailed listing of counts and percentages.

As with photo subjects, sounds associated with photo-log entries had a positive effect on wilderness experience ( $81 \%$ ), only a small portion of sounds had negative effects on the respondent (Figure 7). Respondents who reported "both positive and negative" effects explained their reasoning in the space provided. For example, a respondent may have said "both positive 
Table 6. Count totals and percentages for human-made sounds for $\mathrm{n}=254$ respondents. ${ }^{1}$

\begin{tabular}{lcc}
\hline & $\begin{array}{c}\text { Number of } \\
\text { aggregate reports } \\
\text { that included this } \\
\text { sound type }\end{array}$ & $\begin{array}{c}\text { Percent of } \\
\text { aggregate } \\
\text { human-made } \\
\text { sound reports }\end{array}$ \\
\hline Voices of Others & 205 & 46 \\
Cars \& Motorcycles & 110 & 24 \\
Airplanes & 98 & 21 \\
$\begin{array}{l}\text { Sounds of Self } \\
\text { (heartbeat, breathing, footsteps, own voices) }\end{array}$ & 41 & 9 \\
\hline
\end{tabular}

1 Counts and percents are generalized aggregates of specific reported sound categories.

See Appendix C for detailed listing of counts and percentages.

and negative" to sounds of an airplane and birds singing with the following explanation: "Positive because the birds are part of nature, airplane is negative since it is a man-made intrusion." To better understand respondents' mixed feelings about the sounds they were hearing (both positive and negative affects), further analyses were completed and are presented in the latter portion of this section along with similar photo subject investigation results.

Figure 7. How do the sounds you are hearing affect your wilderness experience?

$1 \%$ of sounds

$13 \%$ of the sounds have both positive $\&$ negative affects on the experience

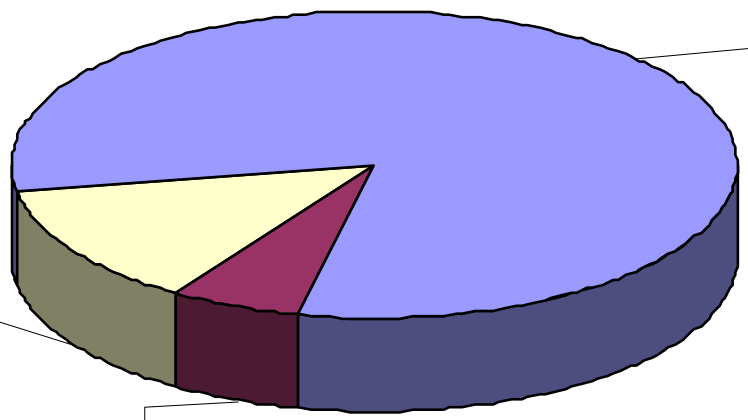
have a positive affect on wilderness experience

$6 \%$ of sounds have

a negative affect on

wilderness

experience

A cross-comparison of human origin and natural origin sounds with effect on wilderness experience shows that almost all of the natural sounds (only) reported (93\%) had a positive effect 
on wilderness experiences. Only $34 \%$ of human sounds (only) reported had a singularly positive effect on respondents' wilderness experiences (Figure 8). Additionally, this comparison reveals that $50 \%$ of the sound reports that include both human and natural sounds had both positive and negative effects on respondents'

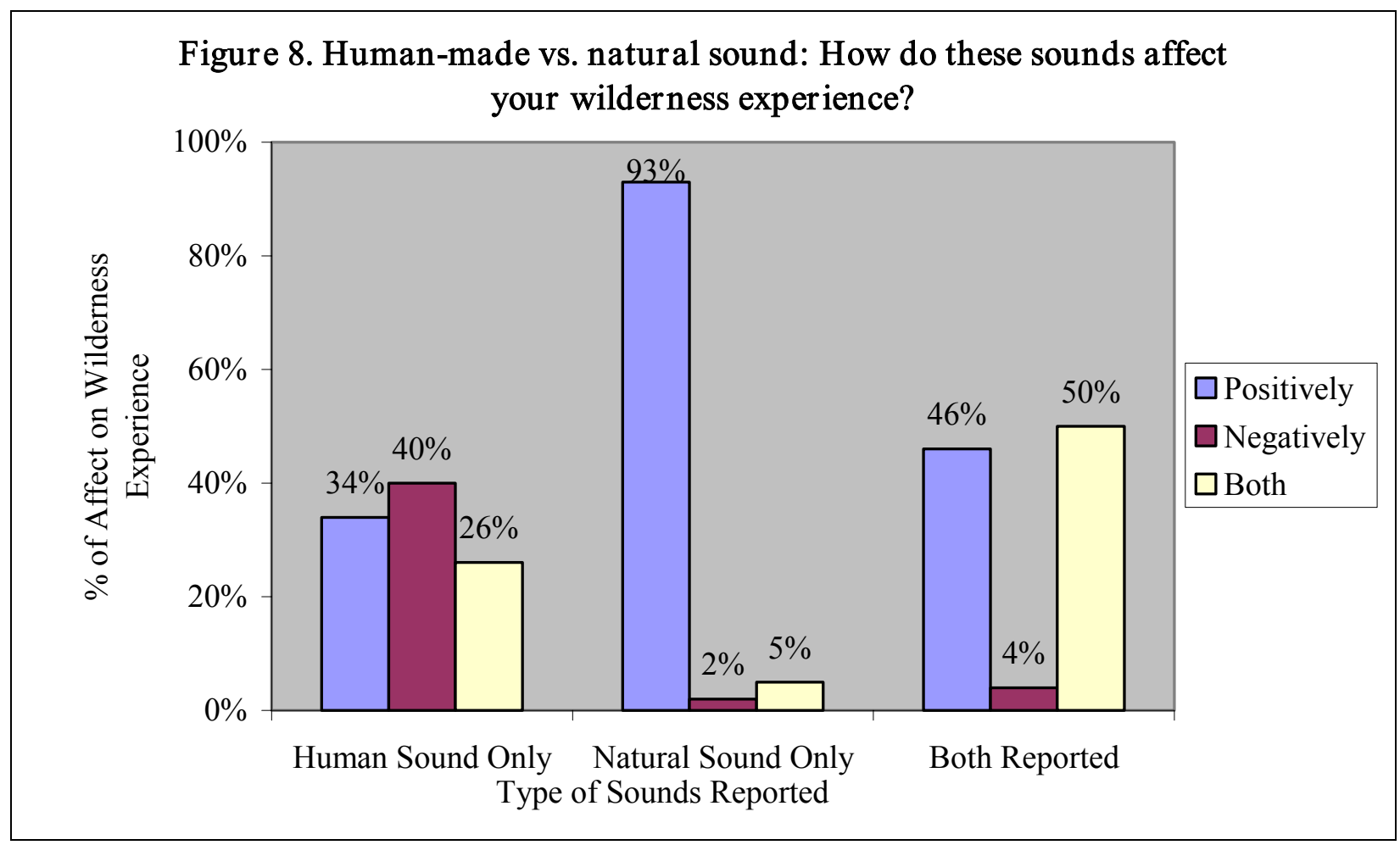

wilderness experiences. As compared to the cross-comparison for photo subjects, sounds of human origin had a more pronounced negative effect on wilderness experience than did visual human subjects. Similar to photo subject comparative results, we can conclude that there is a statistically significant difference among the three types of sound origins (e.g., natural, human origin and sounds originating from both human and natural sources) as they effect respondents' wilderness experiences.

Comparisons of 'specific sound accounts' with 'effect on wilderness experience' were made to determine if different patterns emerged depending on specific types of sound heard (e.g., For mechanized human sounds, does traffic noise have a different effect on wilderness experience than airplane noise?). Sounds that were reported across at least 15 photo-logs, and were described by the respondents as the primary sound heard, were cross-compared with their effect on wilderness experience. As with photo subjects, comparisons were not made for multiple sounds described by the respondent (i.e., a bird, children laughing and an airplane) since it often could not be determined which named sound had the positive or negative effect on the experience at this level of investigation.

Tables 7 and 8 summarize the cross-comparisons of affect with natural and human origin sounds respectively (See Figure $9 \& 10$ for specific passages given by respondents describing sounds). Similar to the general findings for sound effects on wilderness experience, specific natural 
sounds had a strong positive effect on respondents' experiences, with the exception of insect sounds (Table 7). Overall, human sounds affected wilderness experiences more negatively than natural sounds. Only $40 \%$ of voices of other hikers had a positive effect on experiences; a majority of traffic and a preponderance of airplane noises produced negative effects (Table 8).

Table 7. Percent of positive vs. negative effects on wilderness experience for natural sounds only.

\begin{tabular}{lcccc}
\hline $\begin{array}{c}\text { Most reported } \\
\text { natural sounds }\end{array}$ & $\mathrm{n}^{1}$ & \% positive & \% negative & \% both \\
\hline Water & 420 & 99 & 0 & 1 \\
Birds \& Water & 194 & 99 & 0 & 1 \\
Wind & 184 & 84 & 9 & 7 \\
Birds & 128 & 98 & 0 & 2 \\
Wind \& Water & 83 & 96 & 0 & 4 \\
Wind \& Birds & 75 & 96 & 0 & 4 \\
Quiet or Silence & 67 & 97 & 2 & 1 \\
Wildlife other than birds & 30 & 97 & 0 & 3 \\
Birds \& Wildlife & 28 & 100 & 0 & 0 \\
Insects & 21 & 33 & 38 & 29 \\
\hline
\end{tabular}

1 The value of $n$ for this table represents the number of sound reports of only the particular nature sound listed where respondents also provided an evaluation of the sound's effect on wilderness experience. These values for $n$ do not represent the total number of sounds reported for these sound types for the entire data set.

Table 8. Percent of positive vs. negative effects on wilderness experience for human sounds only.

\begin{tabular}{lcccc}
\hline $\begin{array}{l}\text { Most reported } \\
\text { human or human-origin } \\
\text { sounds }\end{array}$ & $\mathrm{n}^{2}$ & \% positive & \% negative & \% both \\
\hline Voices of other hikers & 52 & 40 & 27 & 33 \\
Cars & 29 & 3 & 66 & 31 \\
Voices \& Cars & 16 & 6 & 25 & 69 \\
Airplanes or Jets & 11 & 9 & 91 & 0 \\
\hline
\end{tabular}

1 Sounds of children, breathing, footsteps of respondent \& combinations of these sounds were among the top 10 human sounds most reported, however, a comparison to $+/$ - effect on wilderness experience was not reported due to a small number of these sounds being reported exclusively $(\mathrm{n}<10)$. 
Figure 9. Example explanations of nature sound subjects.

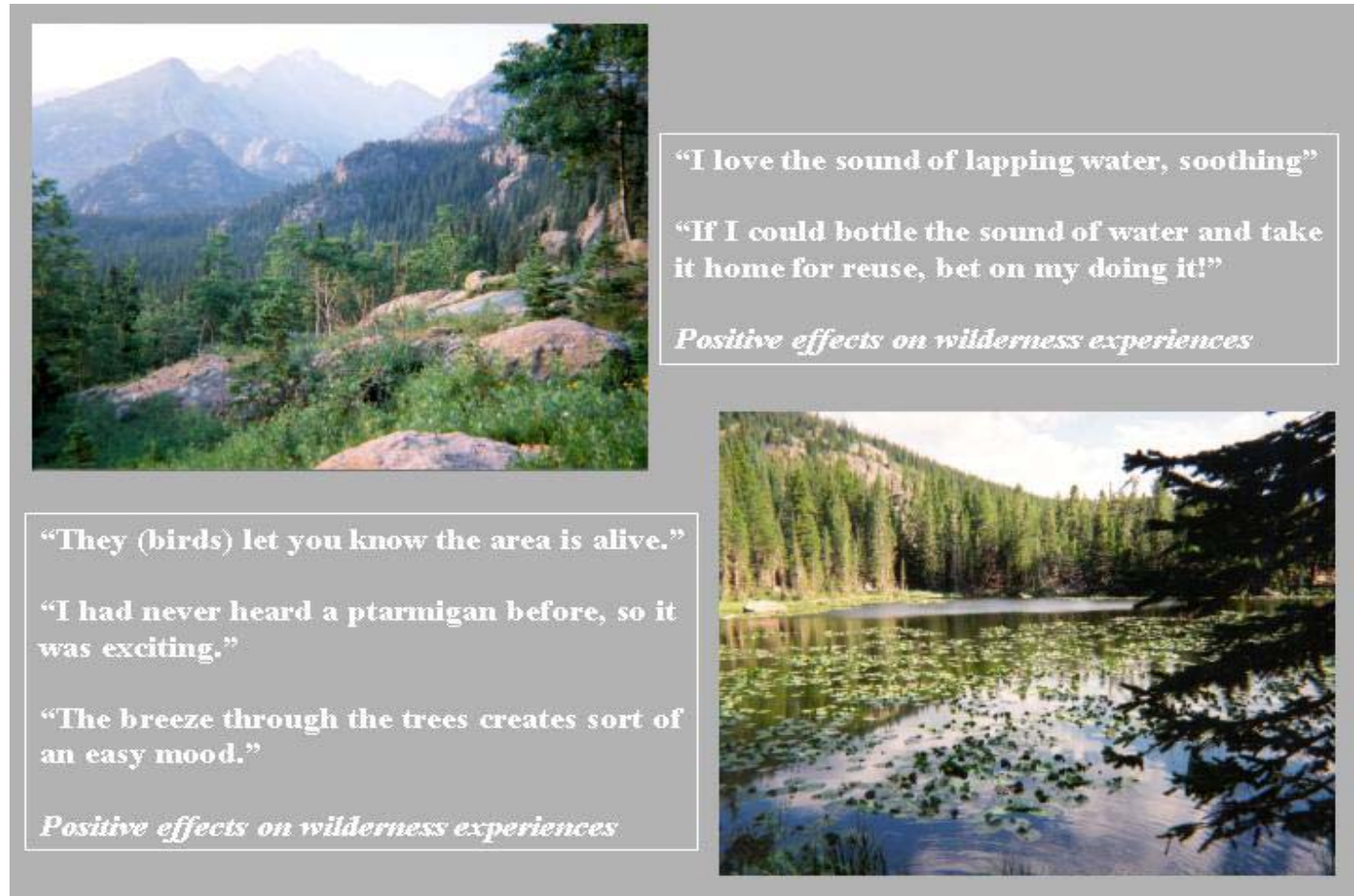

Figure 10. Example explanations of human sound subjects.




Due to a small number of reports of only single sounds it is difficult to draw conclusions about the effect on visitors' wilderness experiences. However, it appears non-mechanized human sounds received more positive comments than mechanized human sounds. Natural sounds, like natural subjects overall, positively enhance wilderness experiences.

Further, in-depth, qualitative analyses were completed to better understand why photo-log subjects and sounds were important to RMNP visitors' experiences. Results from this portion of the investigation are presented in the following section.

\section{Why were these photo subjects and sound-scapes important to Rocky Mountain N.P. visitors' wilderness experiences?}

To better understand how subjects and sounds affected visitors, it was of interest to determine if 'location within the park' played an important role in visitors' perceptions of a wilderness experience. Photo-log entries were analyzed by location subsets to facilitate a richer investigation of wilderness recreation and use experiences. Although emergent patterns did not reveal any strong differences between locations in the park as far as what constitutes a wilderness experience for this group of visitors, the analysis did provide insight and guidance for a qualitative investigation that focused on the conceptual understanding of why various subjects and sounds were important to respondents.

\section{Influence of Location}

A compilation of place names given to describe photo subjects illustrates the diversity of natural regions, places and icons the respondents photographed, and were able to identify by name, in RMNP (See Table C-5). These place names were given by respondents both in the subject descriptions in the photo-logs and, in the follow-up survey as special places not visited. Fourteen lakes, four geological features, five waterfalls and three streams or rivers were named as important to their wilderness experience by ten or more participants in this study. Water and geological features are predominating in the place names volunteered by respondents. Sixty-two lakes, 69 geological features (mountains, glaciers, and rock outcroppings), 17 waterfalls and 17 rivers and streams account for $84 \%$ of all place naming. The most frequently named specific features were Longs' Peak (81), Fern Lake (22) and Alberta Falls (21). These frequencies are in part, governed by accessibility.

Since the concept of "place" and the connection to "place" is an important part of the wilderness experience it was of interest to investigate any potential relationships between region within RMNP and wilderness experience. To find out if respondents' answers differed by region within Rocky Mountain National Park, we first recoded the different trail locations into four regions. The four regions (North Park, Wild Basin/Long's Peak area, Bear Lake area and West Park) coincided with the original sampling plan used for distribution of the cameras and photo-logs. These regions were then compared with photo subject and sound types.

Across all regions of the park, respondents took statistically different proportions of human or human-made subjects compared to natural subject photos; for the Bear Lake region respondents took a greater percentage of natural versus human-made photos than other park regions (Table 9). However, there was no statistical difference between the proportions of human origin sounds versus natural origin sounds heard and reported throughout the park (Table 9). 
Table 9. Comparison of percentages of photo subjects and type of sounds by region surveyed within RMNP.

\begin{tabular}{|c|c|c|c|c|c|c|}
\hline & \multicolumn{4}{|c|}{ Location within Rocky Mountain Nat'l Park } & \multirow[b]{2}{*}{$X^{2}$} & \multirow[b]{2}{*}{$\begin{array}{c}p- \\
\text { value }\end{array}$} \\
\hline & $\begin{array}{c}\text { Bear Lake } \\
\text { Area }\end{array}$ & $\begin{array}{c}\text { Wild Basin } \\
\text { Long's } \\
\text { Peak }\end{array}$ & $\begin{array}{l}\text { West } \\
\text { Park } \\
\text { Area }\end{array}$ & $\begin{array}{l}\text { North } \\
\text { Park } \\
\text { Area }\end{array}$ & & \\
\hline Type of Photo & $\%$ & $\%$ & $\%$ & $\%$ & & \\
\hline Human or Human-made Subject & 15 & 23 & 23 & 25 & & \\
\hline Natural Subject & 76 & 67 & 66 & 68 & & \\
\hline Both & 9 & 10 & 11 & 7 & 26.85 & $<.001$ \\
\hline Type of Sounds & $\%$ & $\%$ & $\%$ & $\%$ & & \\
\hline Human Origin & 8 & 11 & 11 & 6 & & \\
\hline Natural Origin & 78 & 76 & 74 & 79 & & \\
\hline Both Types Reported & 14 & 13 & 15 & 15 & 8.42 & .209 \\
\hline
\end{tabular}

Specific categories of human subject photos and natural subject photos were taken in different proportions throughout the four regions of the park (Table 10). Although a statistical difference exists between these proportions, practically speaking, the differences in the percentage distributions are fairly inconsequential. It is of interest to note that proportionately more photos of human made structures were taken in North park $(61 \%)$ and more photos of people (42\%) were taken in the Wild basin/Long's Peak area. More photos of water features occurred in the Bear Lake and North Park areas (35\% and 33\% respectively) compared to the other two locations and fewer geological, but more vegetation features were recorded in the West park area (Table 10). In sum, these differences in occurrence of photo subject type can be explained by the general nature of each of these park areas (e.g. Wild Basin/Long's Peak area tends to receive high numbers of visitors, resulting in higher proportions of "people" photos, and is a destination area for visitors who wish to see and/or hike Long's Peak, explaining the higher proportion of "geological features" photos.).

Categories of specific sounds were also reported in statistically different proportions across park regions (Table 11). Unlike photo subject differences, however, location did seem to influence type of sound reported at a more practical level, providing some insight into visitors' wilderness experiences. For natural sounds, wind was reported more often in the North Park area (31\%) whereas water sounds were reported most often in the Bear Lake area (32\%) and the Wild Basin/Long's Peak area (32\%). Over half of all human-origin sounds reported by respondents from the North Park area (54\%) and West Park area (52\%) were caused by mechanized human sounds such as airplanes and traffic. Over two-thirds of the human origin sound reports for the Bear Lake (69\%) and Wild Basin/Long's peak (76\%) areas were from non-mechanized noise such as people voices and footsteps. One possible explanation for these differences in the human 
Table 10. Comparison of percentages of photo subjects by region surveyed within RMNP.

\begin{tabular}{|c|c|c|c|c|c|c|}
\hline \multirow[b]{2}{*}{ Types of Photo Subjects } & \multicolumn{4}{|c|}{ Location within Rocky Mountain Nat'l Park } & \multirow[b]{2}{*}{$\begin{array}{c}\text { Range } \\
\text { of } \%\end{array}$} & \multirow[b]{2}{*}{$X^{2}$} \\
\hline & $\begin{array}{c}\text { Bear Lake } \\
\text { Area }\end{array}$ & $\begin{array}{l}\text { Wild Basin } \\
\text { Long's Peak }\end{array}$ & $\begin{array}{l}\text { West } \\
\text { Park } \\
\text { Area }\end{array}$ & $\begin{array}{l}\text { North } \\
\text { Park } \\
\text { Area }\end{array}$ & & \\
\hline Human Subject Photos ${ }^{1}$ & $\%$ & $\%$ & $\%$ & $\%$ & & \\
\hline People & 32 & 42 & 28 & 27 & 15 & \\
\hline Structures & 52 & 46 & 50 & 61 & 15 & \\
\hline Impacts & 14 & 8 & 15 & 12 & 7 & \\
\hline Other & 2 & 4 & 6 & 0 & 6 & $\begin{array}{c}22.65 \\
(p=.007)\end{array}$ \\
\hline Natural Subject Photos & $\%$ & $\%$ & $\%$ & $\%$ & & \\
\hline Water & 35 & 28 & 27 & 33 & 8 & \\
\hline Geological Features & 32 & 35 & 27 & 31 & 8 & \\
\hline Wildlife & 13 & 13 & 13 & 12 & 1 & \\
\hline Vegetation & 18 & 21 & 28 & 18 & 10 & \\
\hline Weather/Celestial & 2 & 3 & 4 & 5 & 3 & \\
\hline Other & 0 & 0 & 1 & 1 & 1 & $\begin{array}{c}34.42 \\
(p=.003)\end{array}$ \\
\hline
\end{tabular}

1 Human subject photos were divided into three general categories: "people" category consisted of photos that the respondent identified people as the primary subject of the picture, "structure" category consisted of photos of any human built structures such as buildings, privies, bridges \& trails, "impact" photos were of human impacts such as initials carved in tree trunks, horse or dog feces, trash \& erosion.

sound-scape that visitors were experiencing in these regions may have been the fact that the Bear Lake and Wild Basin/Long's Peak areas receive a higher number of visitors on trails, whereas, in the North and West Park areas there are fewer recreationists on trails to interfere with hearing the sound produced by distant jet engines or the hum of traffic on the highway.

Comparing Table 11 with Table 8 suggests some differences that might call for different management responses. The Wild Basin/Long's Peak area, for example, shows three-quarters of the human sounds coming form other visitors; sounds that tend to be balanced among positive, 
negative and combined affective responses. In contrast, over half of the human sounds reported in the North and West Park areas are mechanized; sounds with a much higher proportion reporting negative affects (66\% for cars, $91 \%$ for aircraft noise).

Table 11. Comparison of percentages of sound reports by region surveyed within RMNP.

\begin{tabular}{|c|c|c|c|c|c|c|}
\hline \multirow[b]{2}{*}{ Type of Sounds Reported } & \multicolumn{4}{|c|}{ Location within Rocky Mountain Nat'1 Park } & \multirow[b]{2}{*}{$\begin{array}{c}\text { Range } \\
\text { of } \%\end{array}$} & \multirow[b]{2}{*}{$X^{2}$} \\
\hline & $\begin{array}{c}\text { Bear Lake } \\
\text { Area }\end{array}$ & $\begin{array}{l}\text { Wild Basin } \\
\text { Long's } \\
\text { Peak }\end{array}$ & $\begin{array}{l}\text { West } \\
\text { Park } \\
\text { Area }\end{array}$ & $\begin{array}{l}\text { North } \\
\text { Park } \\
\text { Area }\end{array}$ & & \\
\hline Human Origin Sounds ${ }^{1}$ & $\%$ & $\%$ & $\%$ & $\%$ & & \\
\hline Non-mechanized & 69 & 76 & 45 & 44 & 32 & \\
\hline Mechanized & 29 & 22 & 52 & 54 & 32 & \\
\hline Other & 2 & 2 & 3 & 2 & 1 & $\begin{array}{c}35.59 \\
(p<.001)\end{array}$ \\
\hline Natural Origin Sounds & $\%$ & $\%$ & $\%$ & $\%$ & & \\
\hline Wind & 24 & 29 & 25 & 31 & 7 & \\
\hline Water & 32 & 32 & 28 & 25 & 7 & \\
\hline Wildlife/Birds/Insects & 35 & 27 & 37 & 35 & 10 & \\
\hline Weather & 2 & 1 & 3 & 1 & 2 & \\
\hline Other & 7 & 11 & 7 & 8 & 4 & $\begin{array}{c}35.78 \\
(p<.001)\end{array}$ \\
\hline
\end{tabular}

1 Human sounds were divided into two general categories: Non-mechanized sounds consisted of people's voices, footsteps, breathing \& heartbeat. Mechanized sounds consisted of airplanes, vehicular traffic, and construction noise.

\section{Conceptual Dimensions}

Emergent conceptual dimensions were identified from the respondents' explanations as to why photo subjects and sound-scapes had positive or negative effects on wilderness experiences. These dimensions help explain the various complex relationships between photos taken, sounds 
reported and expectations for wilderness experiences. The interplay of these variables in the photo-log exercise sheds some light on what motivates visitors to seek out RMNP wilderness areas and what can potentially detract from such experiences.

Although respondents explained why a particular subject or sound affected their wilderness experience for both natural and human or human-made subjects and sounds, our focus is on the non-natural observations. Respondents' explanations about the non-natural components of their wilderness experience can better illustrate to park managers the impacts of visitors and human encroachment on wilderness areas.

Photo-subjects:

Human or human-made subject photos fell into three broad categories: 1. Human-made structures (i.e., trails, NPS buildings, bridges or historical buildings). 2. Human caused impacts (i.e., carvings on tree trunks, trash, horse feces or erosion), and 3. People (i.e., any photo where the respondent identified the primary subject to be people). Respondents' explanations about effect on wilderness experience consisted of both positive and negative reasons for all of these subject categories to some degree. However, respondents provided abundant responses for both positive and negative explanations for structure photos, whereas, for impacts all explanations were negative and for photos of people most were of a positive nature. Thus, emergent dimensions revealing the complexities of wilderness experience differed among the three types of human subject photos and only the most abundant and practically significant explanations are explored in this report.

Table 12 shows the conceptual dimensions for each type of effect on wilderness experience as well as the percent of statements relating to that dimension within the photo-logs by affect and photo-type.

Human-made structure photos revealed various themes that described positive effects on wilderness experience. Facilitation of a wilderness experience was the most common theme (32\%) especially when respondents described viewing areas or campsites: "Provides an opportunity to view wildlife without having to trek into back country (Bighand viewing area)" or "Great view from our campground".

Many subjects were thought to increase the ability to use or access the park, such as signage or bridges, for example, "We appreciate knowing we've found the correct spot (campsite sign)", "Well maintained trail," and "Bridge is well built and nice, makes hiking easier."

Subjects that indicated that the NPS is preserving land and conserving natural resources constitute a very important aspect of peoples' wilderness experiences: "Nicely marked campsites and privies help people to concentrate their impact and leave more of this place wild." "It's good to see science at work in the park; it helps us to protect the natural environment (hydrological equipment)." "Pleased to see park service is restoring the area and that it is working (restoration sign).”

Subjects that facilitated safety and comfort were also important to respondents' wilderness experiences, "Nice place to have a picnic, plenty of tables, lots of shade" or "Nice stable bridge with handrail." 
Table 12. Percent of statements given by respondents describing various photo subject affects on wilderness experiences. ${ }^{1}$

Conceptual statements by photo-type

$\%$ of Statements

Photos of Human-Made Structures ${ }^{2}$

Why does this photo have a positive effect on your wilderness experience?

Facilitates a wilderness experience

$(\mathrm{n}=194)$

Increases the ability to use or access the park

Indicates that the NPS is preserving land and/or conserving natural resources

Facilities for comfort

Increases safety

Historical importance

Why does this photo have a negative effect on your wilderness experience?

$(\mathrm{n}=50)$

Detracts from wilderness experience

Prevents or interferes with use or ease of access

Environmentally degrading

Decreases safety

10

\section{Photos of Human Caused Impacts ${ }^{3}$}

Why does this photo have a negative effect on your wilderness experience?

$(\mathrm{n}=79)$

Environmentally degrading

Illustrates the negative presence of horses on NPS trails

Detracts from wilderness experience

Prevents or interferes with use or ease of access

Decreases safety

\section{Photos of People ${ }^{4}$}

Why does this photo have a positive effect on your wilderness experience?

Important to share nature/wilderness experience with family $\&$ friends

$(\mathrm{n}=103)$

Reason for visit, to see nature, shows people with a natural feature

Proves, "We did it!"

Demonstrates visitors with the positive aspects of RMNP

Getting back to basics \& returning to nature while visiting RMNP

Illustrates the importance of family and friends spending time together

1 Percentages represent the proportion of statements, related to researcher-identified themes that occurred in respondents' explanations as to why a photo subject had a "positive" or "negative" effect on their wilderness experience. Number of statements precedes percent listing for each group of affect statements.

2 Examples of "human-made structure" photos include, trails, NPS buildings, privies, bridges, ranger stations, historical buildings, visitor centers and bear boxes.

3 Examples of "human caused impact" photos include carvings on tree trunks, trash, horse and dog excrement, and erosion.

4 Examples of "people" photos consist of any photo where the respondents identified the primary subject of the photo to be people. 
Last, in this general category, historical importance was another aspect of a positive wilderness experience, "Dad explained that the bridge was at almost the beginning of the Thompson River. The kids are very interested because of the Thompson Flood."

Negative aspects of human-structure and human caused impact photos were essentially based on the same conceptual dimensions as the positive explanations. Instead of facilitating a wilderness experience, certain subjects detracted from a wilderness experience: "Very poorly reclaimed site, obvious what was here (privy)." "White plaster, pipes are not a natural part of wilderness." "Unbelievable that people litter right on the trail, difficult to enjoy the wilderness." Some photo subjects also prevented or interfered with use of the park: "Pit of outhouse is nearing full, very unpleasant." "Erosion from horses causes dangerous footing on trails."

Photos subjects that implied environmental degradation also affected wilderness experiences negatively: "Trail is poorly marked at this point; people climb all over because they can't find it, causing erosion." "The Pool area is over used with eroded areas and trash." "It illustrates how thoughtless and ignorant people seek to destroy or mutilate the most beautiful part of our world by carving a tree trunk (carved tree)." "Polluting ecosystem (horse feces)".

Connected to the theme of environmental degradation, respondents clearly identified conflicts between hikers and horses by photographing subjects of horse impacts on trails (30\%): "This trail has lots of horse poop. It stinks, so it is nasty. Horse people should at least move the poop off the trail. It reminds me of how many people use the area. The park should ban horses!" "Don't like to share the trail with horses" "I don't like seeing horses on the trail...I believe that if you can't walk back there you shouldn't be there, lazy people!"

Although themes were similar between human impact and structure photos, the magnitude and direction of the sentiments varied if the subject had a positive versus a negative effect on the wilderness experience. For example, facilitating a wilderness experience was the primary reason for why a human-made structure photo had a positive effect on wilderness experience (32\%) and detracting from a wilderness experience was the most frequent reason for the same types of photo subjects producing a negative effect $(53 \%)$. Environmental degradation was the primary reason that human-impact photo subjects had a negative effect on wilderness experience (33\%). Overall, facilitation of a wilderness experience, ability to use or access the park, and effect on environment were the top three themes that respondents repeatedly described when discussing effects on wilderness experience.

In contrast to human-structure or human-impact photos, photos of people-only revealed themes that described the positive effects these photo subjects had on respondents' wilderness experiences. Photos that illustrated family and friends spending time together and sharing in nature or wilderness experiences was a common recurring theme: "I enjoy backpacking with Karen, she is fun and enjoys the outdoors." "My Mom and Grandma don't hike very much, it took a lot to get them out here, but I am glad." The most important explanation for the positive effect of people was sharing nature or wilderness with family and friends (37\%). Although not as common, photos of people spending time together, regardless of the natural setting, also had a positive effect (10\%). Explanations for these subjects centered on people being together, not necessarily a "wilderness experience", for example: "Thankful for a Christian husband that we 
can do things together (photo of husband \& wife)." "We made it, dirty, smelly and all smiles, great friends (end of hike)!"

Photos of people often illustrated the central reason for a hike or outing, to see some sort of natural feature or destination: "We wanted to have a picture taken with wildlife (hiker with squirrel)." Similarly, photos of people demonstrated self-accomplishment or goal attainment, where the photo is proof that "We did it! (group photo at summit of Long's)", "The most harrowing, exciting part of the hike (hiker on steep portion of trail, Long's).", or "Long hike, but worth it! Next year Long's peak! (hikers at end of trail)".

Photos of people also demonstrated getting back to nature while visiting the park, "We enjoy becoming one with nature (filtering water)." Finally, the photos of visitors with the positive aspects of RMNP emerged as a theme explaining the importance of park employees or facilities that allow for better use and enjoyment of the park, "Rangers provide information, maintain order, patrol for safety, tell stories, give out surveys, all very helpful \& needed (hiker with ranger)."

Sound-subjects:

Human origin sounds fell into two major categories: 1. Non-mechanized human origin sounds (i.e., adult human voices and footsteps and the sounds of children) and 2. Mechanized human origin sounds (i.e., traffic and airplane noise). Respondents' explanations about affect of wilderness experience consisted of both positive and negative reasons for all of these sound categories to some degree. However, respondents provided abundant responses for both positive and negative explanations for non-mechanized human origin sound, whereas, for traffic and airplane sounds, explanations were predominantly of a negative nature. As was described for photo subjects, the most abundant and practically significant explanations are explored in this report.

Table 13 shows the conceptual dimensions for each type of effect on wilderness experience as well as the percent of statements relating to that dimension within the photo-logs by affect and sound type.

For non-mechanized sound, four themes emerged that explain why these sounds had a positive effect on the experience. First, respondents reported that hearing others enjoy nature and the park contributed in a positive manner to their own experiences. This explanation was more frequently given than any other reason (44\%), with comments such as: "The Park is for the people!" "Why positive? Because so many people are getting outdoors and enjoying the park." "Good to see others enjoying God's creation."

Respondents also felt that hearing other voices reminded them of the importance of sharing wilderness experiences with others: "Talking kids makes me realize how important this trip is to our family." "People are expected to experience Colorado, we met hikers from Pennsylvania."

Finally, the idea of hearing only a few voices, instead of the many noises you may hear in a city, made some respondents more aware that they were in a wilderness area or they felt safer hearing 
Table 13. Percent of statements given by respondents describing various sound affects on wilderness experiences. ${ }^{1}$

Conceptual statements by sound-type

$\%$ of Statements

Non-mechanized human origin sounds ${ }^{2}$

Why do these sounds have a positive affect on your wilderness experience?

$(\mathrm{n}=55)$

Enjoy hearing others experiencing nature \& the park, "The Park is for the people!"

$44 \%$

Reminder of how important it is to share this experience with others

Only hearing a few voices underscores that this truly is a wilderness experience

Feels good to know you're not alone, safety in numbers

Why do these sounds have a negative affect on your wilderness experience?

$(\mathrm{n}=55)$

Wanted solitude. Indicates that park is too crowded

$42 \%$

Mentally distracting to wilderness experience by interfering with enjoyment

23

Physically irritating, loud, noise interferes with hearing nature sounds

20

Out of place in nature, civilized world encroaching on wilderness

\section{Mechanized human origin sounds ${ }^{3}$}

Why does traffic noise have a negative affect on your wilderness experience?

$(\mathrm{n}=40)$

Reminder of stress \& everyday life, what we came to RMNP to escape

Mentally distracting to wilderness experience by interfering with enjoyment

Out of place in nature, civilized world encroaching on wilderness

Physically irritating, loud, noise interferes with hearing nature sounds

Indications that the noise is negative, however, no explanation given by respondent

Why does airplane noise have a negative affect on your wilderness experience?

Indications that the noise is negative, however, no explanation given by respondent

Out of place in nature, civilized world encroaching on wilderness

Mentally distracting to wilderness experience by interfering with enjoyment

Reminder of stress \& everyday life, what we came to RMNP to escape

Physically irritating, loud, noise interferes with hearing nature sounds

1 Percentages represent the proportion of statements, related to researcher-identified themes that occurred in respondents' explanations as to why sounds had a "positive" or "negative" effect on their wilderness experience. Number of statements precedes percent listing for each group of affect statements.

2 Non-mechanized sounds consisted of human-made sounds, specifically, adult human voices and footsteps, and children.

3 Mechanized sounds consisted of human-made sounds, specifically, traffic and airplane noise.

Respondents also felt that hearing other voices reminded them of the importance of sharing wilderness experiences with others: "Talking kids makes me realize how important this trip is to our family." "People are expected to experience Colorado, we met hikers from Pennsylvania." 
Finally, the idea of hearing only a few voices, instead of the many noises you may hear in a city, made some respondents more aware that they were in a wilderness area or they felt safer hearing others around, "That's all you can hear for miles and it feels great (footsteps)" "Last sign of civilization (voices)" "Others voices reassure me."

Both non-mechanized and mechanized noises had negative effects on wilderness experience. The complaint that hearing human voices interfered with solitude and indicated that the park was too crowded was the number one explanation given for why non-mechanized noises had a negative effect: "The people are negative since you would like to get away from them, that's the idea (voices of adults \& children)." "I came up here for solitude, not a party (cell phone users)."

Sounds that reminded respondents of stress and their attempt to escape everyday life by coming to RMNP were very common among respondents, constituting the reason given most often for why traffic noise had a negative effect on the experience ( $30 \%$ of negative explanation for this sound type).

Respondents often noted that the noises they were hearing were mentally distracting to the wilderness experience and interfered with their enjoyment: "Crowds of people are distracting from the peace \& harmony of the setting." "Jets distract from my wilderness experience." "Only drawback that takes away from wilderness experience is the number of planes crossing over. They are intrusive."

Aside from being mentally distracting, many noted that negative noises were physically irritating and interfered with hearing the sounds of nature: "Jet ruined the bird songs." "Traffic noises are annoying and loud." "Loud children make it impossible to appreciate the sounds of birds, etc."

Another strong reason that noise had a negative effect on wilderness experiences was the thought that the noises were out of place in nature and were a reminder that the civilized world was encroaching on nature: "City \& industrialized world vs. the silence of natural world (cars \& people)." "I hear this back home at the daycare across the street (children)." "It seems less wildernessy (jet)." "Airplane, awful sound of civilization deep in wilderness." Explanations based on the idea that the sounds heard were out of place in nature were most common for airplane noise $(25 \%)$ and frequent for traffic noise $(23 \%)$. However, the primary reason why airplane noise was negative was simply that it was negative, without any explanation given $(30 \%)$ whereas, for traffic noise, only $7 \%$ of the statements simply suggested that traffic was negative without further explanation. Although both airplane and traffic sounds were overwhelmingly viewed as having a negative effect on wilderness experiences, respondents' explanations as to what makes these sounds negative varies considerably between the two sounds types. 


\section{The Follow-up Survey}

The survey was mailed as a follow-up to the camera exercise, accompanying the respondents' copies of their photos. The survey consisted of three sections addressing 1) which places in RMNP have special importance to visitors and what constitutes a wilderness experience to them, 2) a set of hypothetical sight and sound scenarios and their impact on visitors' wilderness experience, 3 ) three sets of questions eliciting information about visitors' emotions during their visit, their level of attachment to the Park, and their opinions about environmental issues in general. Section three was part of the coordination between several studies conducted in RMNP during the summer of 2002. It was not directly related to the camera exercise and the results are therefore not included in this report. In addition, respondents were asked a series of basic experience and demographic questions.

\section{Important Places}

The first two questions of the follow-up survey were intended to identify places that have special importance to visitors of Rocky Mountain National Park. Respondents were asked which one of their photographed places, from their visit to the Park, was most important to their wilderness experience. In this question, visitors were prompted to identify the "peak" picture out of the ten possible photographs taken (Table 14 and Table D-1). We gave respondents the option to identify specific place names, but there was too much variety to present specific features, such as "Cub Lake," in a meaningful way. Instead, we combined specific places under frequent categories, i.e. "Lake or Pond".

Table 14. Most important photographed place to wilderness experience $(n=134)^{1}$

\begin{tabular}{lcc}
\hline Subject & $\mathrm{n}$ & $\%$ \\
\hline Lake/Pond & 37 & 28 \\
Mountain/Glacier & 25 & 19 \\
View/Scenery & 15 & 11 \\
Wildlife & 11 & 8 \\
Waterfall & 9 & 7 \\
Stream & 6 & 5 \\
\hline
\end{tabular}

\footnotetext{
$1 \mathrm{n}=$ represents the number of responses to this question. Subjects listed by less than $5 \%$ of respondents were not included in the table, therefore $\mathrm{n}$ does not sum to $100 \%$. See Appendix D-1 for a complete list of subjects
}

"Lake/Pond" and "Mountain/Glacier" in Table 14 are aggregate categories both including photographs featuring the combination of a mountain with a lake. Some of the respondents $(n=9)$ seemed to be especially intrigued by the beauty of an alpine lake with a mountain or mountain range in the background. The category "Mountain/Glacier" also includes the view of a mountain, and the summit of a mountain. A substantial number of all "best" pictures $(\mathrm{n}=52)$ had some water source in it, which again highlights the importance of water to visitors of the Park. Some respondents had difficulties identifying one "peak" photograph. To them, all of RMNP 
represented a peak experience. As one visitor put it, "I can't really pick one picture. The Park as a whole is much more important to me than just a certain section of it."

The second question of the follow-up survey asked respondents if there are other places in RMNP that are especially important to them, but were not visited during the trip when they took the pictures. The reason for this question was to make sure that visitors had the opportunity to list their other special places, even if they were not accessible on the day the camera was handed out. Responses for this question were first analyzed separately and then added to the most photographed places from the photo-log (see Table C-5).

\section{Meaning of Wilderness Experience}

Three questions in the follow-up survey were intended to measure what constitutes a wilderness experience to visitors of RMNP. First, we asked respondents to select one most important reason for visiting the Park on this trip from the four statements below (Table 15). There was no significant difference between day hikers and overnight users on selection of these statements.

Table 15. Most important reason for visiting RMNP by user group $(\mathrm{n}=128)^{1}$.

\begin{tabular}{lcc}
\hline Reason for visiting RMNP & Day hiker & Overnight user \\
\hline $\begin{array}{l}\text { I came here because I enjoy the } \\
\text { Backcountry/Wilderness itself }\end{array}$ & $64 \%$ & $73 \%$ \\
$\begin{array}{l}\text { I came here because it is a good place to } \\
\text { do some of the activities that I enjoy }\end{array}$ & 23 & 9 \\
$\begin{array}{l}\text { I came here because I wanted to spend } \\
\text { more time with my family/companions }\end{array}$ & 10 & 12 \\
$\begin{array}{l}\text { I came here to gain a fresh perspective } \\
\text { on life }\end{array}$ & 3 & 6 \\
\hline Total & 100 & 100 \\
\hline $\begin{array}{l}1 \mathrm{n}=\text { represents the number of responses to this question. } \\
2 \text { Chi-square was not significant, } \mathrm{p}>0.05 .\end{array}$
\end{tabular}

A majority of day hikers (64\%) and overnight users (73\%) came to RMNP because they enjoy the backcountry or wilderness itself. In other words, other aspects of a park visit (i.e. activities like hiking, or being with friends and family) might enhance the experience, but the existence of wilderness in RMNP is extremely important to visitors in and by itself. Day hikers (23\%) placed more emphasis on being able to do the activities they enjoy in the Park than overnight users $(9 \%)$.

The next question asked visitors if they considered themselves to be in the wilderness when visiting RMNP. Figure 11 indicates that a majority of day hikers and overnight users $(68 \%$ and $65 \%$, respectively) felt that "being in wilderness" depends on where they were in the Park. Interestingly, none of the overnight users said that they did not consider themselves to be in wilderness. This might be related to the distance overnight backpackers travel into the Park and 
the remoteness of the areas they reach during their trip. Most overnight users might travel through, but do not stay in the more crowded front country areas of the Park for long periods of time. Close to one third of both user groups indicated that they, in fact, did consider themselves to be in wilderness while at RMNP. Very few, day hikers only, did not consider their experience to be in wilderness.

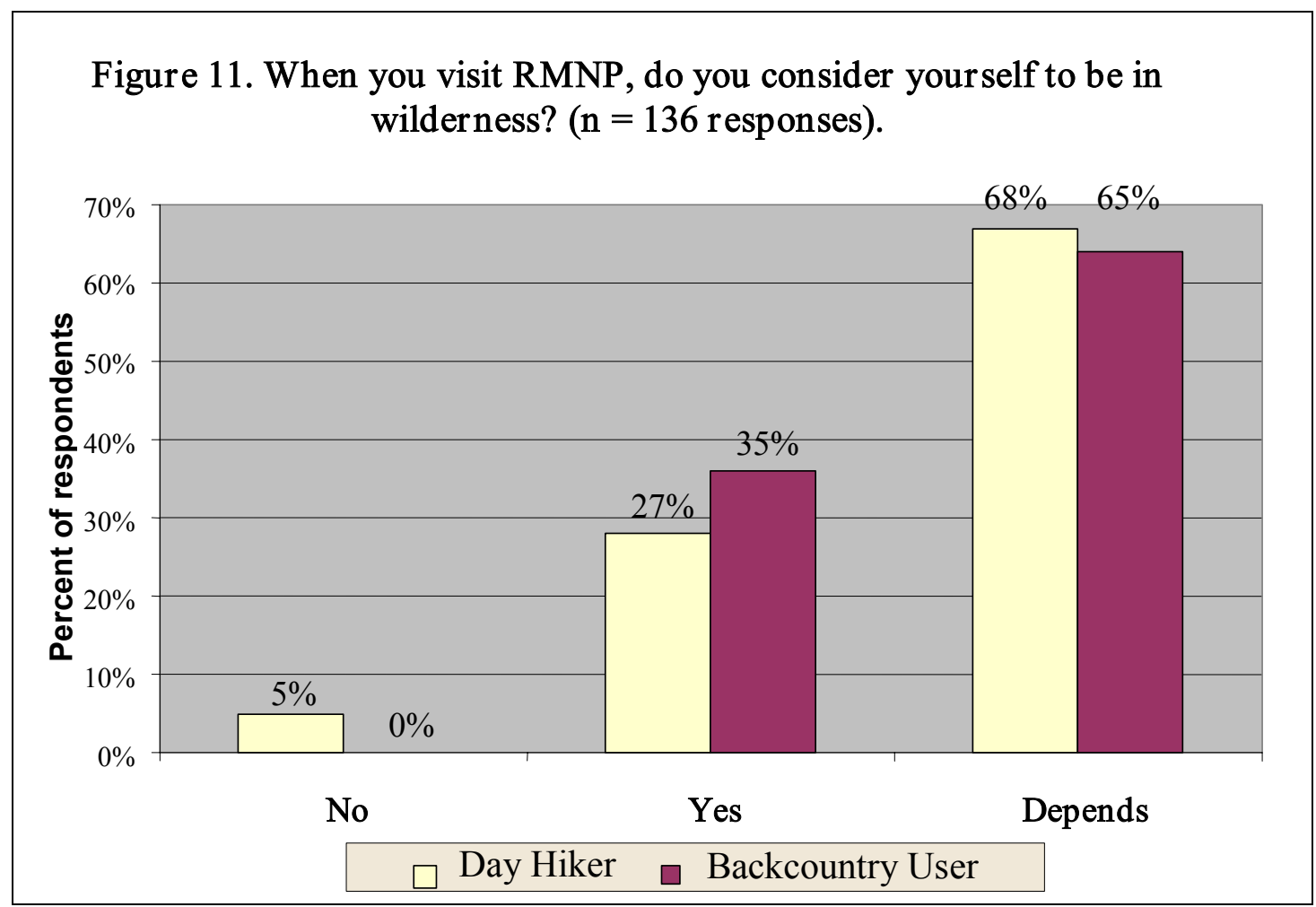

One of the goals of this study was an attempt to combine quantitative with qualitative measures of wilderness experience in order to gain a deeper understanding of what aspects visitors' value most in wilderness. Therefore, we included a number of open-ended questions in the follow-up survey. Although harder to analyze, qualitative research has the potential to provide resource managers with an abundance of information often overlooked in strictly quantitative studies.

One of the open-ended questions asked respondents to describe, in their own words, what the experience of being in the wilderness at RMNP means to them. Qualitative analysis is subjective to a certain extent. To lower the chances of researcher bias, two people read the responses to this question several times, independently, to come up with certain "wilderness experience themes." Eleven different themes began to emerge from this content analysis. After creating the categories or themes, one researcher counted all the responses for each of the categories, to be able to prioritize them. Another researcher cross-checked about one third of all the themes and the responses put under each category. Then the eleven "wilderness experience themes" were prioritized by frequency of mention (Table 16). Sub-categories among the main themes were identified and prioritized as well (see Table D-2). 
Table 16. Important wilderness experience themes $(n=322)^{1}$

\begin{tabular}{lcc}
\hline Theme $^{2}$ & $\mathrm{n}$ & $\%$ \\
\hline Aesthetics & 82 & 25 \\
Physical Escape & 55 & 17 \\
Solitude & 46 & 14 \\
Therapeutic (feeling) & 27 & 8 \\
Back to Basics & 21 & 7 \\
God & 20 & 6 \\
Exercise/Health & 19 & 6 \\
Goal Attainment & 19 & 6 \\
Introspection (thinking) & 13 & 4 \\
Feeling of awe & 11 & 3 \\
Socializing & 9 & 3 \\
\hline Total & 322 & 100 \\
\hline
\end{tabular}

$1 \mathrm{n}=$ represents the number of responses to this question; respondents could list more than one experience.

2 Themes "emerged" from content analysis of question 5.

Respondents mentioned aspects pertaining to "aesthetics" most often $(n=82)$ when asked to give a definition of wilderness experience in the Park. Descriptions such as "being able to take in sights, sounds, smells of an awesomely beautiful place", "fantastic scenery", "the anticipation of knowing you could see wildlife at almost any moment if you keep your eyes open", and "the opportunity to enjoy nature in a relatively primitive unspoiled state" were all part of this category.

The second most stated meaning of wilderness experience was "physical escape" $(\mathrm{n}=55)$, or an opportunity to get away from everyday life, the city, work, or people for a while. As one respondent put it: "I feel like RMNP is my area to escape modern civilization", or another "It means a chance to escape from the stress of everyday life". According to these statements, a certain percentage of visitors to the Park seem to be in need of these temporary physical escapes to maintain their overall well being.

Statements belonging to the theme "solitude" were ranked third in terms of frequency of mention $(\mathrm{n}=46)$. The words "solitude", "peace", "relaxation", and "no crowds or human impacts" occurred several times within this category. Being in the wilderness also meant the lack of noise to many visitors: "It gives me a chance to hike deep into areas where there are no people and contain no noise. Even if only for a short while, this is valuable beyond words." 
The wilderness, the theme of having a therapeutic value to visitors of the Park, emerged as another important meaning in our study $(\mathrm{n}=27)$. Many visitors felt "refreshed", "invigorated" or "rejuvenated" after a trip to the wilderness. Respondents talked about experiencing a "feeling of being alive and happy" or a "feeling of being at peace" that did not only occur while being in the Park, but - for some respondents - lasted for a certain time after the trip had ended. One visitor explained: "even though we only spend about one and a half weeks a year here, it feels like it affects my life year round".

The category "back to basics" $(\mathrm{n}=21)$ included ideas such as: "re-connecting with nature and oneself", "stripping away what is non-essential", or "visiting another place or world". One respondent stated that "being there allows you to remember what life is truly about and not all the material things that you're flooded with in everyday society". Wilderness in RMNP gives some visitors the feeling of "being at home" and others "the feeling of being an explorer, trying to imagine what the earth was like before human alteration".

Twenty of the responses had to do with God in one way or another. For many visitors to RMNP, being in wilderness seems to be a very spiritual experience. Respondents talked about "experiencing God", "God's creation in nature" or "feeling very close to God". To use the words of one respondent: "it [the wilderness] speaks to me of God in my heart". Some people view a visit to the wilderness as a substitute for going to church.

"Exercise and health" $(\mathrm{n}=19)$ was another theme emerging from the responses for this question. Specific activities, such as hiking, camping or fishing were essential to some visitors' wilderness experience. For other respondents, simply getting exercise and fresh air were just as important.

"Adventure", "self-reliance", "challenge", and "a sense of accomplishment" were all categorized under a theme we called "goal attainment" $(n=19)$. Many visitors talked about the personal satisfaction they achieve from challenging themselves to reach a goal: "what keeps me coming back is the satisfaction I find in pushing myself physically and mentally to complete hikes that are demanding from a stamina and navigational standpoint”.

Another very important meaning of wilderness for visitors to the Park is the ability to "gain a fresh perspective on life", "to think and reflect on life". Thirteen of the responses were included into a category we termed "introspection". One visitor explained wilderness as "a place where you can hear yourself think. I often get a clearer look at life when we are in the woods. Most important life decisions have been made here". This category also includes "memories" and "tradition".

The "feeling of awe" category $(n=11)$ includes statements from visitors expressing their "wonder and marvel at nature". One visitor wrote:" I love the intimacy of a canyon and the immensity of the areas above timberline". Other respondents talked about the "vastness of nature" and about "feeling very, very small". This specific meaning of wilderness seems to be hard to explain, although one respondent's words probably elucidate what a lot of people felt: "If more people could experience the wilderness and realize that man is just one part of a much grander plan, the world could be better". 
The last category, in explaining visitors' meaning of wilderness experience, was "socializing" $(\mathrm{n}=9)$. It simply meant for respondents to be with their family or friends in nature. To be with their loved ones made the experience even better and more meaningful.

\section{Complexity of Wilderness Experience}

Another important observation emerged from our analysis of the question what the experience of being in the backcountry or wilderness at RMNP means to visitors. Through the content analysis of responses to this question we found that, for most visitors, wilderness experience does not consist of just one of the above-mentioned themes. Many respondents mentioned several themes as being equally important to their wilderness experience in the Park. The average number of themes mentioned per respondent was 2.3 , with many visitors offering up to five or more themes as an explanation. Following are two examples of this complexity: "I experience everything I enjoy and everything that is important to me when I'm on a trail at RMNP. I experience relaxed time with my family, re-connect with nature and with myself. I get exercise and fresh air. I get a sense of accomplishment and I think"; and "It simply is a time to enjoy the beauty, quietness and expansiveness of nature. A time to rest, reflect and rejuvenate without intrusion from the outside world". This observation leads us to the conclusion that the meaning of wilderness experience is not a simple, straightforward construct for visitors, but rather a very complex one. Such complexity seems almost impossible to measure with just quantitative scales if we want to understand the richness of meaning of "Wilderness Experience".

\section{Effect of Changes in the Environment on Visitors' Wilderness Experience}

Along with the follow-up survey, we sent respondents, who finished the camera exercise, a complete set of their photographs, together with copies of two of their photo-log pages. In the follow-up, we provided respondents with a set of hypothetical sound and sight scenarios intended to measure if and how these changes in the environment would affect their wilderness experience (Figures 12 and 13). These hypothetical situations were specifically geared towards two of the photographs they took while visiting the Park: one photograph for sound and the other for sight changes. We enclosed copies of the photo-log pages describing the pictures to help visitors remember these specific places. The sight and sound scenarios were "inserted" into respondents' original wilderness experience (represented by the two photographs). Then effects of these changes were measured quantitatively by scales and qualitatively by asking visitors to describe how these changes altered their experience.

We sent respondents equal numbers of two different versions of the follow-up survey. The scenarios differed between the two survey versions, to allow for a greater variety of "background environments" (trail, open area, scenic vista, and water) and to broaden the number of hypothetical changes in these environments we could test (Figures 12 and 13). The scenarios were chosen to include issues that emerged from the camera exercise, discussions with wilderness managers, and the RMNP Backcountry/Wilderness Management Plan (RMNP, 2001). 
Figure 12. Trail and Open Area scenarios.

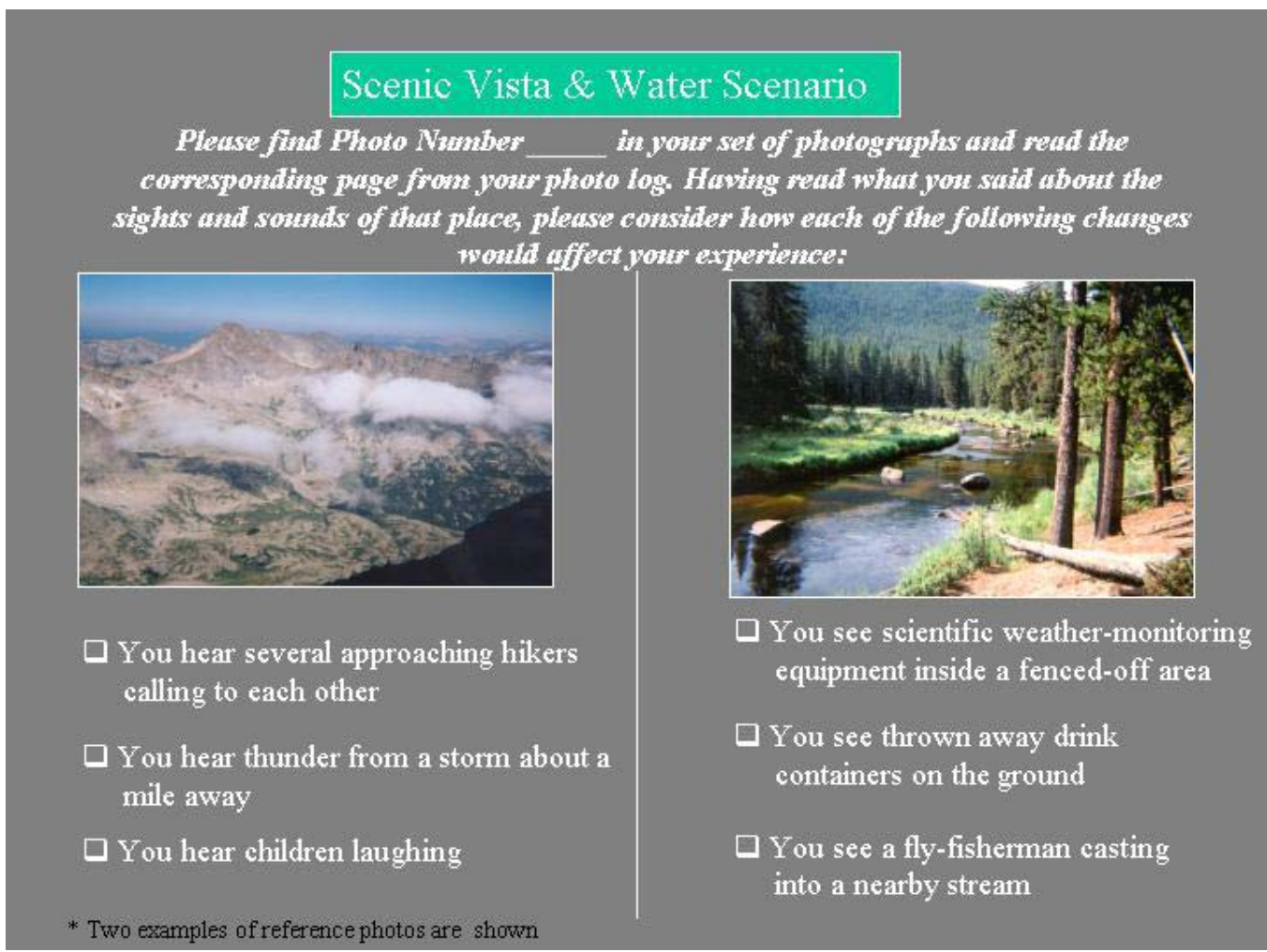

Figure 13. Scenic Vista and Water scenarios.

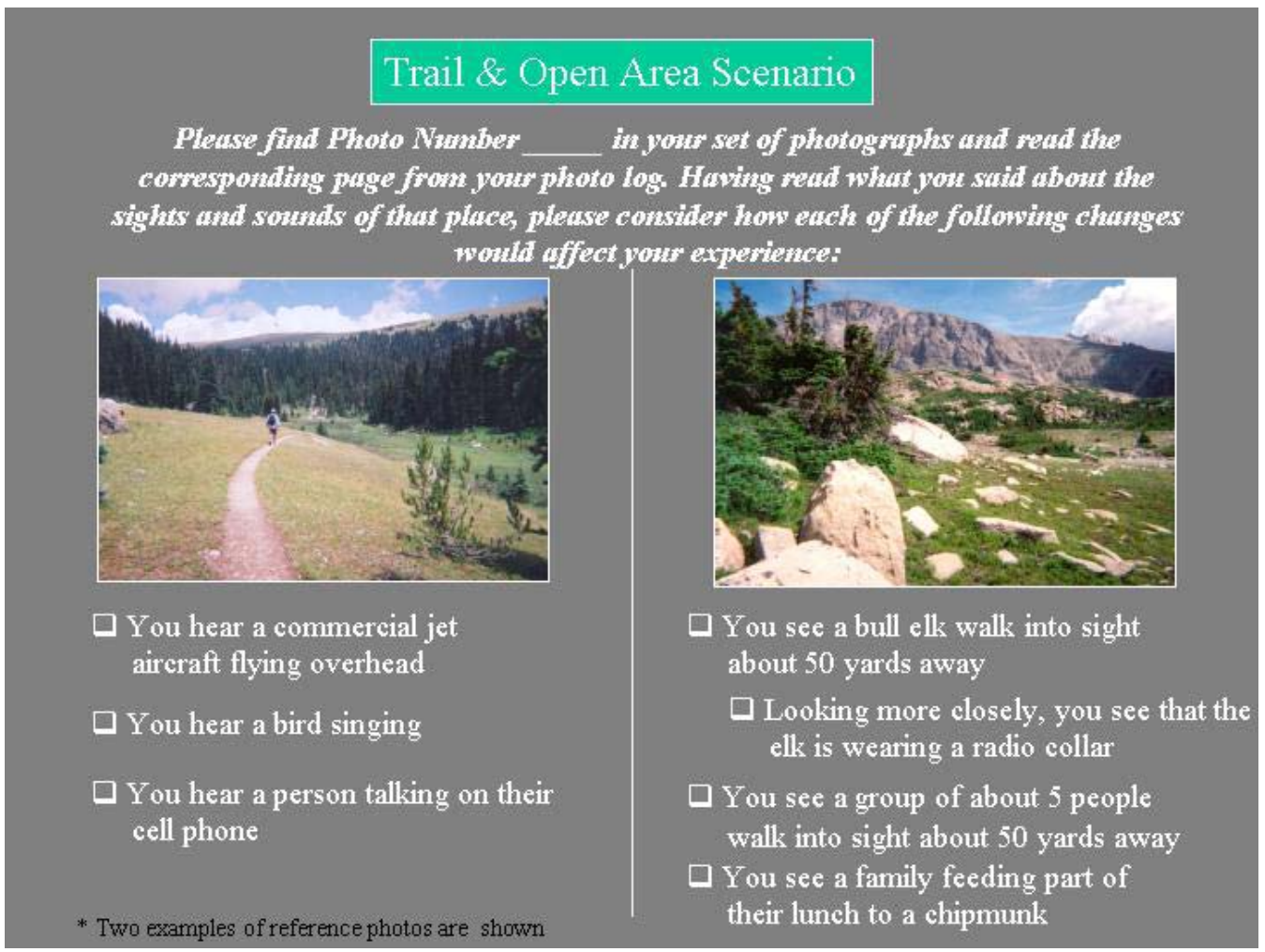




\section{Effects of Sounds}

For the first part of the exercise, we asked respondents to indicate on a scale, how much each change would enhance or detract from their experience of this place. The scale had ten points from $1=$ "greatly detracts" to $10=$ "greatly enhances". Table 17 shows the results for the sound scenarios from both survey versions.

Table 17. The effect of sounds on visitors' wilderness experience in RMNP.

\begin{tabular}{lccc}
\hline Change $^{1}$ & Mean & Minimum & Maximum \\
\hline $\begin{array}{l}\text { You hear a bird singing } \\
\text { You hear thunder from a storm a } \\
\text { mile away (?) }\end{array}$ & 9.1 & 5 & 10 \\
$\begin{array}{l}\text { You hear children laughing (?) } \\
\text { You hear several approaching hikers } \\
\text { calling to each other (-) }\end{array}$ & 5.5 & 1 & 10 \\
$\begin{array}{l}\text { You hear a commercial jet aircraft } \\
\text { flying overhead (-) }\end{array}$ & 2.8 & 1 & 10 \\
$\begin{array}{l}\text { You hear a person talking on their } \\
\text { cell phone (-) }\end{array}$ & 2.0 & 1 & 8 \\
\hline
\end{tabular}

1 Variables coded on a scale from $1=$ "greatly detracts" to $10=$ "greatly enhances."

2 A plus sign (+) indicates that a high mean was expected, a minus sign (-) indicates that a low mean was expected, and a question mark (?) indicates that the outcome for the analysis was not predicted.

As shown in the table above, the song of a bird had the most positive effect on visitors' wilderness experience, with a mean of 9.1 on the scale. All the responses to this scenario were clustered along the upper ("enhances") portion of the scale. We truly did not know how visitors would rate the statements "you hear thunder from a storm a mile away" and "you hear children laughing". Both changes ranked around the mid-point of the scale, with thunder having a slightly more positive effect $(\underline{M} e a n=6.5)$ than the laughs of children $(\underline{M}=5.2)$. The next three sound scenarios, illustrated in Table 17, all detracted from visitors' wilderness experience, with the sound of a cell phone rated most negative $(\underline{M}=2.0)$. Like a mirror image to the bird scenario, all the responses for the cell phone scenario were clustered in the lower ("detracts") portion of the scale. Ninety percent of respondents felt that the use of cell phones in the wilderness would detract from their experience (see Figure D-1). Hearing a commercial aircraft also greatly detracted from visitors' wilderness experience in the Park $(\underline{M}=2.8)$. "You hear several approaching hikers calling to each other" had a slightly negative effect, with a mean of 3.7 on the scale.

Figure 14 shows a visual comparison of how "a person talking on their cell phone" and "several approaching hikers calling to each other" altered the wilderness experience of visitors to RMNP. It becomes obvious from the figure that almost all of the respondents considered the use of a cell 
phone as a great detraction from their experience. Nobody thought it would enhance his or her experience. The sound of other hikers was also considered negative by a majority of visitors, but there was a much wider range of responses, with about $25 \%$ of respondents just slightly below the neutral point.

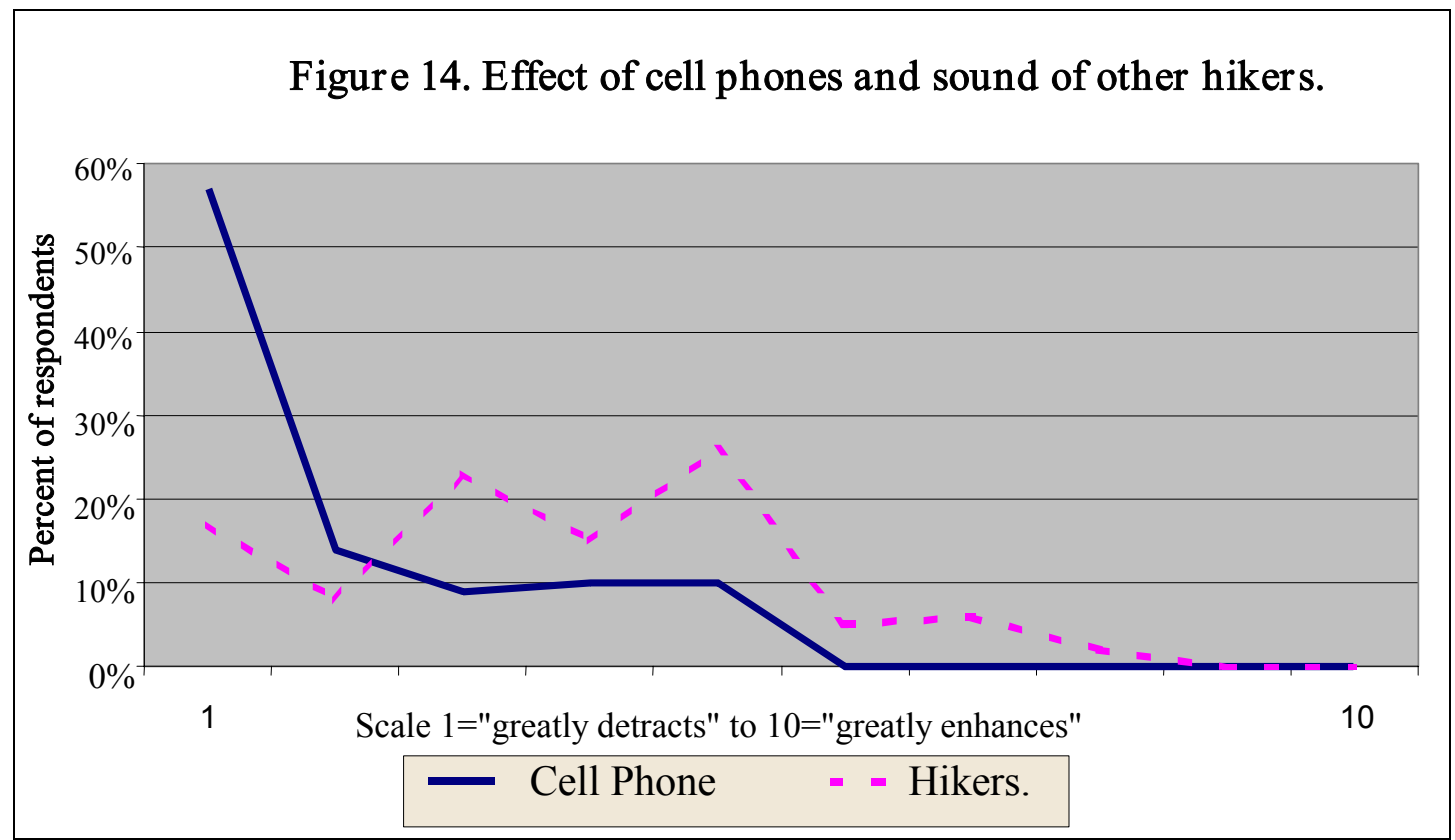

\section{Effect of Sights}

Comparable to the sound changes, we gave respondents a variety of sight scenarios and asked them to indicate on a scale from $1=$ "greatly detracts" to $10=$ "greatly enhances", how much each change would enhance or detract from their experience of this place (see Figures 12 and 13). The results for the sight scenarios can be found in Table 18.

The only sight item that had a greatly enhancing effect on visitors' wilderness experience was the "bull elk walking into sight" $(\underline{M}=9.3)$. Interestingly, the mean dropped four whole points on the scale to around neutral $(\underline{M}=5.3)$ when the scenario changed to an elk with a radio collar. The flyfisherman was considered slightly positive $(\underline{\mathrm{M}}=6.5)$, whereas "the group of 5 people walking into sight" was slightly negative $(\underline{\mathrm{M}}=4.6)$. The next three scenarios in Table 18 detracted more or less from visitors' wilderness experience. The statement "you see scientific weather-monitoring equipment" had a mean of 3.8 compared to 2.8 for "the family feeding a chipmunk". The change which affected visitors to the Park most negatively, including both sight and sound scenarios, was to see drink containers scattered on the ground $(\underline{\mathrm{M}}=1.3)$. In other words, $98 \%$ of all respondents to this question indicated that littering, i.e. drink containers on the ground, greatly detracted from their experience (see Figure D-2). 
Table 18. The effect of sights on visitors' wilderness experience in RMNP.

\begin{tabular}{lccc}
\hline Change $^{1}$ & Mean & Minimum & Maximum \\
\hline $\begin{array}{l}\text { You see a bull elk walk into sight, } \\
\text { about 50 yards away (+) }\end{array}$ & 9.3 & 5 & 10 \\
$\begin{array}{l}\text { Looking more closely, you see that } \\
\text { the elk is wearing a radio collar (?) }\end{array}$ & 5.3 & 1 & 10 \\
$\begin{array}{l}\text { You see a fly fisherman casting into a } \\
\text { nearby stream (?) }\end{array}$ & 6.5 & 1 & 10 \\
$\begin{array}{l}\text { You see a group of about 5 people walk } \\
\text { into sight, about 50 yards away (?) }\end{array}$ & 4.6 & 1 & 10 \\
$\begin{array}{l}\text { You see scientific weather-monitoring } \\
\text { equipment inside a fenced-off area (?) }\end{array}$ & 3.8 & 1 & 8 \\
$\begin{array}{l}\text { You see a family feeding part of their } \\
\text { lunch to a chipmunk (-) }\end{array}$ & 2.8 & 1 & 10 \\
$\begin{array}{l}\text { You see thrown away drink containers } \\
\text { on the ground (-) }\end{array}$ & 1.3 & 1 & 5 \\
\hline
\end{tabular}

1 Variables coded on a scale from $1=$ "greatly detracts" to $10=$ "greatly enhances"

2 A plus sign (+) indicates that a high mean was expected, a minus sign (-) indicates that a low mean was expected, and a question mark (?) indicates that the outcome for the analysis was not predicted

Figure 15 allows us to compare respondents' ranking of "a bull elk walking into sight" with "the elk wearing a radio collar". We can see that for an overwhelming majority of visitors, the sighting of a bull elk greatly enhanced their wilderness experience. Opinions changed when the elk was equipped with a collar. The excitement of seeing the elk was lessened and far more people rated the experience as neutral.

T-tests between day hikers and overnight users did not show significant differences on any of the sound or sight scenarios. In other words, whether a change in the environment enhanced or detracted from their wilderness experience did not depend on the type of use. Both groups of Park users felt very similar concerning these statements. 


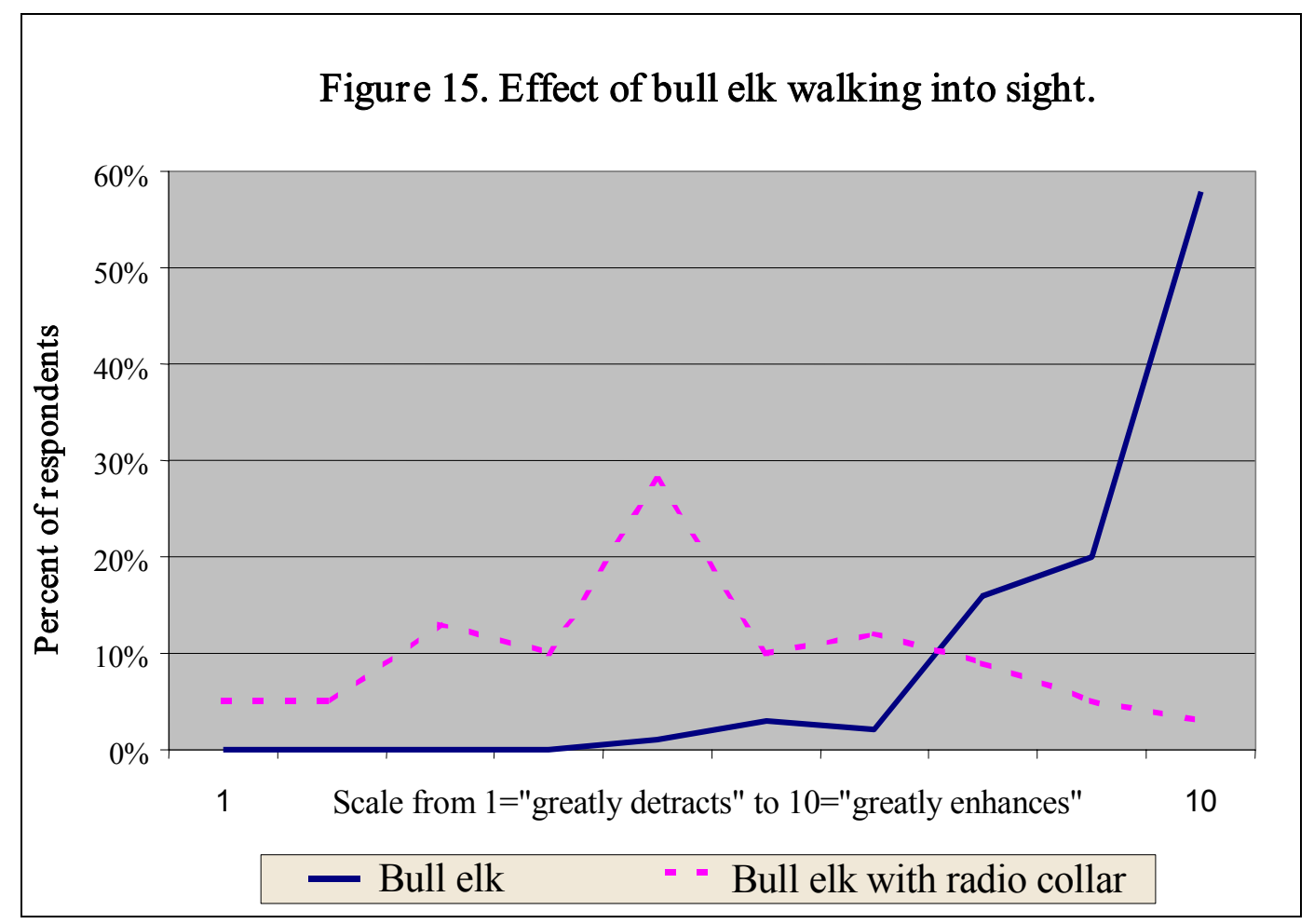

\section{Verbal Descriptions}

In addition to the scales, we had respondents describe in their own words if and how each of the changes affected their wilderness experience. The open-ended format of the questions allowed for more in-depth information than would have been possible with just the ten-point scales. The reader should be aware of the fact that the results for respondents' verbal statements do not necessarily coincide with their quantitative scale ratings.

Similar to the qualitative part of the photo-log analysis earlier in this report, we wanted to find out if respondents' answers differed by the four regions (Bear Lake, Wild Basin, West and North Park areas) in RMNP. The statistical tests performed did not show a significant difference among regions on any of the scenarios. Therefore, visitors' responses are analyzed across all locations, rather than by regions.

We used the qualitative analysis software program N'Vivo to analyze visitors' open-ended responses to all the statements. First, we coded the responses for each of the sound and sight scenarios as either "enhancing", "neutral", or "detracting" from the wilderness experience. The different responses were put into separate "nodes" in N'Vivo. After printing all the "node-coding reports" for each of the scenarios and reading through them several times, certain "themes" with similar ideas began to emerge under each "node". When all the themes were established and given a code number, we coded each open-ended visitor response under the appropriate theme and counted the responses to provide for a quantitative way of presenting the data. Results for the two sets of sound scenarios are summarized in Tables 19 and 20. 
Instead of discussing each theme within a scenario separately, we will concentrate on pointing out what we believe are the most important observations, as well as differences and commonalties among the scenarios.

\section{Verbal Descriptions of Sounds}

For a majority of the respondents $(n=63)$, hearing a commercial aircraft detracted from their wilderness experience (Table 19). The most important explanations were that "the sound of the airplane brought them back to "civilization", "detracted from the peaceful surroundings", and "intruded into this otherwise quiet location". For some respondents $(n=18)$, the aircraft did not alter their experience. Some of them thought that "jets are a necessity in the $21^{\text {st }}$ Century" and that "they are fairly high up in the sky and therefore not that noticeable" and disruptive to the experience.

Hearing a bird singing was a positive experience for almost all visitors. The most common explanations were that the sound of a bird is "part of the nature experience" and that "it belongs in the Park". Some visitors said that it is a "pleasant sound creating positive feelings" or that they "enjoyed identifying the birds". Two respondents stated that it would not alter their experience, because they "expected birds to be in the Park". Fewer respondents answered this question $(n=65)$ than the aircraft and cell phone questions $(n=81$ and $n=86$, respectively).

None of the survey participants thought that the sound of cell phones would enhance their wilderness experience. A majority of responses $(n=76)$ were negative. Visitors felt that listening to a person talking on their cell phone would "remind them of work and stress" and that it would be a rather disrespectful "invasion of their privacy". Participants thought that cell phones are negative because they "interrupted the feeling of being in the backcountry". Some respondents suggested that "cell phone usage should be limited" in the Park and only used for emergency calls. Others stated that "cell phones should not be allowed" in RMNP at all. A few $(n=10)$ were more neutral about cell phones: "Ok, just not to conduct business" or "It's only momentary".

The sound of other hikers calling to each other (Table 20) mostly detracted from visitors' wilderness experience $(n=40)$. Many people felt that this sound would be "a disturbance to the silence, solitude, or beauty of the wilderness". A substantial amount of respondents stated that it would "interrupt their physical escape from everyday life". Most visitors who were neutral on this scenario $(n=29)$ felt that others had the "same right to be in the Park to enjoy the same experiences", or "shared their pleasure".

Hearing thunder was a rather positive experience for a slight majority of the respondents $(n=35)$. Common explanations were that this sound is "part of the outdoor experience" and that they loved the "beauty of a storm" in the backcountry. A substantial amount of visitors, including some who rated the sound as positive, thought that thunder so close would be a distraction to their wilderness experience, because it could be "dangerous" or "plan altering". 
Table 19. How sounds alter visitors' wilderness experience (Trail Scenario).

\begin{tabular}{|c|c|c|}
\hline "You hear a commercial aircraft flying overhead" & & $\mathrm{n}=81^{1}$ \\
\hline ENHANCES: ${ }^{2}$ & $(0 \%)$ & 0 \\
\hline NEUTRAL: & $(22 \%)$ & 18 \\
\hline Jets are part of 21 st Century; Jets are a necessity & & 5 \\
\hline Jets are fairly high up and therefore not that noticeable & & 5 \\
\hline Thankful to be enjoying the day in the park instead of in an airplane & & 2 \\
\hline If there are not too many, no problem & & 2 \\
\hline A single jet is momentary & & 2 \\
\hline Like to watch their contrails go across the sky & & 1 \\
\hline Jet aircraft are much quieter than 5-10 years ago & & 1 \\
\hline DETRACTS: & $(78 \%)$ & 63 \\
\hline Brings me back to 'civilization’; Brings me back to reality & & 27 \\
\hline Detracts from peaceful surroundings; Feels less like backcountry & & 16 \\
\hline Sound intrudes on this quiet location; Aircraft hides natural sounds & & 14 \\
\hline Spoils the mood; Annoying; Not as relaxing & & 3 \\
\hline Disturbs wildlife & & 2 \\
\hline Resent the pollution & & 1 \\
\hline \multicolumn{2}{|l|}{ "You hear a bird singing" } & $\mathrm{n}=65$ \\
\hline ENHANCES: & $(97 \%)$ & 63 \\
\hline Part of nature experience; Adds to beauty and solitude; Belongs there & & 30 \\
\hline Increases awareness and appreciation for wilderness; Makes me happy & & 15 \\
\hline Enjoy identifying birds; I came here to enjoy wildlife & & 12 \\
\hline There is more to the park than is seen by the eye; Audible nature reminder & & 4 \\
\hline Reminder of the past & & 1 \\
\hline Want to be a bird in the park - & & 1 \\
\hline NEUTRAL: & $(3 \%)$ & 2 \\
\hline Expect to hear birds & & 2 \\
\hline DETRACTS: & $(0 \%)$ & 0 \\
\hline \multicolumn{2}{|l|}{ "You hear a person talking on their cell phone" } & $\mathrm{n}=86$ \\
\hline ENHANCES: & $(0 \%)$ & 0 \\
\hline NEUTRAL: & $(12 \%)$ & 10 \\
\hline Once in a while is ok, just not to conduct business; It's only momentary & & 6 \\
\hline $\mathrm{Ok}$, if the call is important & & 2 \\
\hline Could use cell phone to call for help & & 1 \\
\hline Reminds you that you can still communicate with the world & & 1 \\
\hline DETRACTS: & $(88 \%)$ & 76 \\
\hline Brings me back to 'civilization'; Reminder of work and stress & & 22 \\
\hline Spoils the mood; Annoying; Disrespectful; Invasion of privacy & & 16 \\
\hline Cell phone usage should be limited, unless for emergency & & 16 \\
\hline Disconnects from nature experience; Feels less like backcountry & & 13 \\
\hline Cell phones should not be in the wilderness at all & & 9 \\
\hline
\end{tabular}

$1 \mathrm{n}=$ represents the number of responses to this question

2 Note: respondents' verbal descriptions usually matched their scale ratings. If they did not match, we chose the verbal description for categorization 
Table 20. How sounds alter visitors' wilderness experience (Scenic Vista Scenario).

\begin{tabular}{|c|c|c|}
\hline \multicolumn{2}{|l|}{ "You hear several approaching hikers calling to each other" } & $\mathrm{n}=71^{1}$ \\
\hline ENHANCES: & $(3 \%)$ & 2 \\
\hline Good to share and compare; Sometimes nice to speak to other hikers & & 2 \\
\hline NEUTRAL: & $(41 \%)$ & 29 \\
\hline No problem, it's their park also; They enjoy the same experience I enjoy & & 15 \\
\hline I share their pleasure, unless they are shouting loudly or complaining & & 9 \\
\hline Although it breaks the sound of nature, they will pass on; Only momentary & & 3 \\
\hline You can avoid other hikers, popular areas, crowds & & 2 \\
\hline DETRACTS: & $(56 \%)$ & 40 \\
\hline Disturbs silence; solitude; scenery; beauty; Feels less like wilderness & & 24 \\
\hline Brings me back to 'civilization'; Interrupts escape from real world & & 12 \\
\hline Disrespect for wildlife, nature, and others; Scares wildlife; Scares people & & 4 \\
\hline \multicolumn{2}{|l|}{ "You hear thunder from a storm about a mile away" } & $\mathrm{n}=67$ \\
\hline ENHANCES: & $(52 \%)$ & 35 \\
\hline I like the sound of thunder; I love storms; Part of outdoor experience & & 20 \\
\hline I like storms, but fear lightning; Love beauty, but concerned about safety & & 14 \\
\hline Stirs memories of times shared with friends & & 1 \\
\hline NEUTRAL: & $(15 \%)$ & 10 \\
\hline It's a neutral event, I expect it; Uncontrollable part of the outdoors & & 10 \\
\hline DETRACTS: & $(33 \%)$ & 22 \\
\hline I would be nervous about lightning so close; Danger & & 14 \\
\hline Distracting or plan altering; I would head back to my car & & 8 \\
\hline \multicolumn{2}{|l|}{ "You hear children laughing" } & $\mathrm{n}=69$ \\
\hline ENHANCES: & $(49 \%)$ & 34 \\
\hline I love children; Nice to hear children laughing in any environment & & 18 \\
\hline I like to see children in the wilderness; Future conservationists & & 15 \\
\hline NEUTRAL: & $(22 \%)$ & 15 \\
\hline It's distracting, but I'm pleased children are enjoying the area & & 11 \\
\hline Unless the children are yelling, it wouldn't greatly affect experience & & 3 \\
\hline Occasional sounds like that are ok & & 1 \\
\hline DETRACTS: & $(29 \%)$ & 20 \\
\hline Disturbs silence; Detracts from natural sounds and scenery & & 9 \\
\hline Brings me back to 'civilization' & & 5 \\
\hline Annoying; Don't like children & & 4 \\
\hline Scares wildlife away & & 2 \\
\hline
\end{tabular}

$1 \mathrm{n}=$ represents the number of responses to this question

2 Note: respondents' verbal descriptions usually matched their scale ratings. If they did not match, we chose the verbal description for categorization

The statement "you hear children laughing" was considered positive by half of the respondents to this question $(n=34)$ based on their comments, although equal proportions rated this sound as enhancing, neutral, or detracting from the experience (see Figure D-1). Affection for children in general and the idea of children developing into "future conservationists of the Park" made this 
scenario an enhancing experience. Some respondents $(\mathrm{n}=15)$ thought that the laughter of children would not alter their experience and for others $(\mathrm{n}=20)$ it was a rather negative sound. "It detracts from natural sounds and scenery", "it brings me back to "civilization', "it is annoying", and "it scares wildlife away" were just a few comments.

\section{Verbal Descriptions of Sights}

Results for the two sets of sight scenarios are summarized in Tables 21 and 22. Sixty-eight responses or $99 \%$ of all statements were positive when respondents imagined "a bull elk walking into sight" (Table 21). Most people said that it is "always neat to see wildlife" and that "it completes the nature experience". Some visitors pointed out that it is exciting, because "you don't see a bull elk in the city".

When the elk was wearing a radio collar, a third of the respondents were positive, stating that "science should be conducted to learn from the Park". Twenty-five responses were neutral about the collared elk. Many respondents would "prefer the wildlife to be left alone," but they "understand the need for studies within the Park." For some visitors this sight would alter their wilderness experience in a negative way $(\mathrm{n}=18)$. They felt that the collar is "just another way of humans interfering with nature" and that the "Park would feel more like a zoo."

A slight majority of the responses $(n=36)$ to the group of five people walking into sight were neutral. Common explanations included "I realize that everyone has a right to enjoy the Park", or "as long as they are quiet, it does not affect my experience". Others were more negative about this sighting because they "came here to get away from people" and "the chances of seeing wildlife and enjoying solitude are greatly reduced". A few $(n=7)$ felt that seeing others enjoying the Park would enhance their experience.

To see a family feeding a chipmunk greatly detracted from most respondents' wilderness experience ( $\mathrm{n}=57)$. Many survey participants noted that it "would disturb the balance of nature" or that it is "a violation of the law". Some visitors felt that it is not a positive thing to do, but that "it is understandable" for children wanting to interact with wildlife.

Scientific weather-monitoring equipment (Table 22) was considered neutral by a slight majority of visitors ( $\mathrm{n}=35)$. Respondents felt that it "detracted to an extent", but they also "understood the need for scientific studies in the Park". A substantial number of respondents mentioned that the equipment would be "without effect if it blended well into the surroundings" or was "situated out of the way of busy or scenic areas". Other respondents were more negative (n=28) stating that the scientific equipment would "take away from the natural setting or viewing experience". Some visitors wrote that it would be a "greatly detracting, visually ugly sight" or that it would "make me feel close to 'civilization'. Interestingly, respondents were much less positive about this type of scientific equipment than about the radio collar on the elk.

None of the respondents were happy about seeing "thrown away drink containers on the ground". The preponderance of the responses (98\%) was negative. A majority of participants said that it would "completely alter their wilderness experience" and that it would show a "great disrespect from people for the environment". Some respondents were disappointed about the 
Table 21. How sights alter visitors' wilderness experience (Open Area Scenario).

\begin{tabular}{lcl}
\hline "You see a bull elk walk into sight, about 50 yards away" & $\mathrm{n}=69^{1}$ \\
\hline ENHANCES: & $(99 \%)$ & 68 \\
Always neat to see wildlife; I love wildlife; Exciting & 33 \\
Adds to the experience; It completes the nature experience & 29 \\
You don't see that in the city; Does not occur on a daily basis at home & 6 \\
NEUTRAL: & $(1 \%)$ & 1 \\
I would be nervous, unless I was informed that they are not dangerous & $(0 \%)$ & 0 \\
DETRACTS: & & $\mathrm{n}=64$ \\
\hline & & \\
"Looking more closely, you see that the elk is wearing a radio collar" & $(33 \%)$ & 21 \\
& & 21 \\
\hline ENHANCES: & $(39 \%)$ & 25 \\
Science should learn from and within the park; I am interested in research & 20 \\
NEUTRAL: & 3 \\
I would like wildlife to be left alone, but also understand need for studies & 2 \\
No real impact & $(28 \%)$ & 18 \\
It may detract somewhat from beauty of animal, but would still be neat & & 18 \\
DETRACTS: & & \\
Seems more like a zoo; It feels less natural; Humans interfering with nature & & \\
\hline
\end{tabular}

\begin{tabular}{|c|c|c|}
\hline "You see a group of about 5 people walk into sight, about 50 yards away" & & $\mathrm{n}=68$ \\
\hline ENHANCES: & $(10 \%)$ & 7 \\
\hline It's good to see others enjoying the same experience & & 7 \\
\hline NEUTRAL: & $(53 \%)$ & 36 \\
\hline I realize everyone has a right to enjoy the park & & 18 \\
\hline As long as they are quiet and not disruptive, it's a neutral experience & & 8 \\
\hline I'm ok with just us, but not upset seeing others either & & 6 \\
\hline I hike early to avoid crowds; This is ok, but we start early to avoid crowds & & 4 \\
\hline DETRACTS: & $(37 \%)$ & 25 \\
\hline Came here to get away from people; I'd rather not hear or see any humans & & 16 \\
\hline Chances of seeing wildlife and enjoying solitude are greatly reduced & & 8 \\
\hline They should show more respect and stay on the trail & & 1 \\
\hline
\end{tabular}

"You see a family feeding part of their lunch to a chipmunk" $\quad \mathrm{n}=68$

ENHANCES:

It is nice to see people interacting with wildlife, it's safe

Sharing with God's creation some things that humans rarely do

NEUTRAL:

Not good, but I understand their enjoyment

It does not alter my experience; Oh well, if it's a carrot I'm ok

DETRACTS:

Not good to tame wildlife; People disturbing the balance of nature

Fine these people; People stupidly breaking the law

Ends up being litter; I'm sure some litter will be left behind

Could be bad for the family (bite - rabies etc.)

$1 \mathrm{n}=$ represents the number of responses to this question

2 Note: respondents' verbal descriptions usually matched their scale ratings. If they did not match, we chose the verbal description for categorization 
"self-centeredness and lack of concern for other Park users" and others said that they "detest the pollution" and "pick trash up and carry it out" whenever they hike in RMNP.

Table 22. How sights alter visitors' wilderness experience (Water Scenario).

"You see scientific weather-monitoring equipment inside a fenced-off area" $\quad n=68^{1}$

\section{ENHANCES:}

I'm happy to have someone doing scientific studies to help management It has the potential to enhance experience if its presence is explained NEUTRAL:

A distraction, but I understand the need for scientific investigation

No impact if done in a way that blends into surroundings

No problem; I don't have a problem with it. I can take it or leave it

I can just move somewhere else

DETRACTS:

Takes away from natural setting; Takes away from my viewing experience

Love not seeing human presence; Makes me feel close to 'civilization'

It would be a great distracting, visually ugly sight

"You see thrown away drink containers on the ground"
$(7 \%)$

5

3

2

$(51 \%) \quad 35$

16

12

6

1

$(41 \%) \quad 28$

13

8

7

\section{ENHANCES:}

NEUTRAL:

Pick it up and move on

$\mathrm{n}=83$

It's not good, but the sort of thing I expect to some degree so close to a road DETRACTS:

No respect for environment or nature; Completely alters the experience It shows self-centeredness and the lack of concern for others

$(0 \%) \quad 0$

$(2 \%)$

2

I pick them up and haul them out; Will pick up the trash; Detest pollution!

\begin{tabular}{|c|c|c|}
\hline "You see a fly-fisherman casting into a nearby stream" & & $\mathrm{n}=66$ \\
\hline ENHANCES: & $(50 \%)$ & 33 \\
\hline It's good to see people enjoying nature in a peaceful way; Romantic & & 30 \\
\hline I enjoy fly-fishing as long as it's catch and release & & 3 \\
\hline NEUTRAL: & $(44 \%)$ & 29 \\
\hline This doesn't really bother me. They are enjoying nature in their own way & & 15 \\
\hline I don't fish, so this is a neutral activity; No significant change & & 9 \\
\hline Neutral, however beginners are clumsy; litter left behind (i.e. fishing line) & & 4 \\
\hline He might be in the spot I hiked to get to - requires an alternative plan & & 1 \\
\hline DETRACTS: & $(6 \%)$ & 4 \\
\hline The fisherman is another park user which detracts from solitude & & 2 \\
\hline There are plenty of other areas (not RMNP) available to the sportsman & & 2 \\
\hline
\end{tabular}

For half of the respondents, seeing a fly-fisherman in a stream would be an enhancing experience $(n=33)$. A common explanation was that it is "good to see people enjoying nature in a peaceful way" that "fits into the environment". Respondents who were neutral about this scenario stated 
that the fisherman was "just another Park user enjoying nature in his own way" or that it would not alter their experience because "they do not fish themselves".

Two of the themes detracting from visitors' wilderness experience occurred throughout most of the scenarios. The first theme incorporates the idea that certain sounds (i.e. aircraft, cell phones, other people) and sights (i.e. scientific equipment) brought visitors back to 'civilization' or back to the reality they tried to escape from for a while. The second theme shows that these sounds and sights disconnected from or interrupted their nature experience and made it feel less like wilderness. The one theme that occurred for a majority of the scenarios, enhancing visitors' wilderness experience, showed the opposite. Respondents stated that certain sounds (i.e. birds, thunder) and sights (i.e. bull elk) were part of the outdoor experience, added to the experience, or completed the nature experience. Some of the sounds and sights detracted or enhanced visitors' experience in the Park more than others. For a majority of people, laughing children were considered far more positive than the sound of other hikers in the area; and scientific equipment was considered far more positive than drink containers on the ground.

Another interesting observation was that the approval or disapproval of other visitors depended on how people behaved and the type of activities they participated in while visiting the Park. Many respondents expected and accepted the fact that other people would be in RMNP. Common responses included "I realize that everyone has the right to enjoy the Park" or "they [other visitors] enjoy the same experience I enjoy". But if other people were disruptive or loud, the experience was rated far more negatively: "I share their pleasure, unless they are shouting loudly or complaining". Recreational activities in the Park seem to be more accepted by visitors if they are perceived to be peaceful, and non-destructive (i.e. fly-fishing) compared to more environmentally impacting activities such as horseback riding.

\section{The Respondents}

Most respondents to the follow-up survey had visited the backcountry and front country of Rocky Mountain National Park many times before this trip (see Table 23). The average respondent started visiting the Park 17 years ago. Including the current visit, respondents had visited the backcountry 3.8 and the front country 2.8 times in the past 12 months. They were experienced wilderness users with an average of 12.2 past visits to other wilderness areas. Visitors felt fairly familiar with and even more attached to the Park.

Table D-3 shows that, out of the 140 respondents who answered the follow-up survey, 59\% were male, between the ages of 26 and $55(67 \%)$, and grew up in a small or medium city (54\%). Respondents were very well educated, with $48 \%$ having graduate or professional training. Most respondents (83\%) were not students anymore at the time of the survey and had an annual household income of more than $\$ 35,000(84 \%) ; 23 \%$ reported an income of more than $\$ 100,000$ per year.

Tests for differences within demographic variables (gender, age, childhood residence, education, and income) on different questions from the follow-up survey revealed some interesting results that might be worth further investigation. A t-test for differences among gender showed significant differences between males and females on three of the scenarios. Female visitors rated the sound scenarios "you hear a commercial aircraft flying overhead" (F- $\underline{M}=2.2, M-$ 
$\underline{\mathrm{M}}=3.3)$, "you hear a person talking on their cell phone" (F- $\underline{\mathrm{M}}=1.6, \mathrm{M}-\underline{\mathrm{M}}=2.3)$, and "you hear children laughing" (F- $\underline{M}=4.4, M-\underline{M}=5.7)$ consistently more negatively than males. These results indicate that females might be more sensitive towards "introduced sounds" in wilderness. In this case, female visitors would be at a higher risk of loosing a quality wilderness experience if certain sounds were present. At this point of investigation, we can only speculate about the results, but it might be of interest to do some more research on this topic.

Table 23. Follow-up survey experience variables $(n=140)^{1}$.

\begin{tabular}{lc}
\hline Variable & Mean \\
\hline How many times have you visited RMNP before this trip? & \\
Visits to Backcountry/Wilderness: & 10.2 \\
$\begin{array}{l}\text { Visits to developed Front country: } \\
\text { How many years ago did you first visit RMNP? }\end{array}$ & 10.7 \\
$\begin{array}{l}\text { Including this current visit, how many times did you visit } \\
\text { RMNP in the past 12 months? }\end{array}$ & \\
$\begin{array}{l}\text { Visits to Backcountry/Wilderness: } \\
\text { Visits to developed Front country: }\end{array}$ & 3.3 \\
$\begin{array}{l}\text { Approximately how many other Backcountry/Wilderness } \\
\text { areas have you visited in the past? }\end{array}$ & 2.8 \\
$\begin{array}{l}\text { How familiar are you with RMNP? } \\
\text { (Scale from 1="not at all" to 10="extremely familiar" }\end{array}$ & 12.2 \\
$\begin{array}{l}\text { How attached are you to RMNP? } \\
\text { (Scale from 1="not at all" to 10="extremely attached" }\end{array}$ & 6.6 \\
\end{tabular}

$1 \mathrm{n}=$ represents the number of returned surveys.

A cross-tabulation between a lower $(<\$ 5,000$ to $\$ 49,999)$ and higher income group $(\$ 50,000$ to $>\$ 100,000)$ showed a significant difference on the question "when you visit RMNP, do you consider yourself to be in wilderness?" Almost three fourths (72\%) of visitors in the high-income group checked the response "it depends on where I am in the park", compared to about half (54\%) of the visitors in the low-income group. This result might indicate that people in the higher income group hike further into the backcountry to be able to have a true wilderness experience and/or might be more familiar with the whole Park.

Another interesting observation was that the two income groups differed on two of the hypothetical scenarios. "You hear a bird singing" (Hi- $\underline{M}=9.2, \underline{L}-\underline{M}=8.4)$ and "you see a bull elk walking into sight, about 50 yards away" (Hi- $\underline{M}=9.5$, Lo- $\underline{M}=8.4)$ were both considered more enhancing to the experience by the high-income group than by the lower income group, although both groups were very positive about the sounds and sights of wildlife.

It is important to point out that none of the other tests performed showed any significant difference. In other words, a majority of the experience and demographic variables did not explain any differences in response. 


\section{Discussion}

\section{What have we learned about wilderness experiences in RMNP?}

Overall, many of the results from the two survey exercises reinforce one another. These results, taken together, underscore the importance visitors place on beauty and nature as being central to wilderness experiences and the role of RMNP as a place to escape everyday life. The results also provide insight into how respondents view the impacts from other recreationists and non-natural human influence on park experiences. By examining the results from these survey efforts we can get a clearer picture of why visitors come to RMNP wilderness areas and what hinders those experiences.

Respondents' definitions of a wilderness experience closely coincide with the types of photos as well as the descriptions of the photo subjects recorded in the photo-logs. In the follow-up survey, when defining a wilderness experience "aesthetics" was the most frequently mentioned theme.

Respondents' descriptions of the importance of natural settings in a wilderness experience detailed the beauty and scenic integrity of areas found in places like RMNP. In fact, the most important reason given for visiting the park was to visit the wilderness areas themselves. Similarly, the photos that respondents identified as "peak" photos were mostly of natural subjects that reflected this desire to be surrounded by wild beauty in a picturesque setting. Parallel to the follow-up results, the photo-logs revealed that $93 \%$ of all natural subject photos had positive effects on wilderness experiences. Likewise, $93 \%$ of the natural sounds reported also had a positive effect on wilderness experiences. In sum, being surrounded by nature, wilderness sights and sounds, and beauty is the first-order theme that explains what is central to park visitors' wilderness experiences.

The park was also identified as a place of escape from civilization and everyday life, a secondorder theme. Both the follow-up survey and the photo exercise revealed that RMNP plays a central role in providing a refuge from urban dwellings where the enjoyment of nature is best when uninterrupted. It is apparent that natural subjects and sounds enhance and facilitate this escape while visiting the park. Human made subjects and sounds often disrupt or detract from this escape. For example, both the camera and follow-up exercises showed that mechanized human sound (i.e. airplanes and cars) had a strong negative effect on experiences. Such sounds were described as being out of place in nature acting as an intrusion by bringing them back to civilization. Human voices however, were more expected and tolerated in the park by respondents.

Another theme evident from the description of wilderness experience as well as from the effects of sound on experience during the photo exercise, is peace and quiet, solitude and silence. This can be interpreted as the opposite of "escape from" as it often is what the wilderness user is "escaping to". This theme, of course, is even more sensitive to the intrusion of human or humanmade sounds, e.g., "Wanted solitude. Indicates that the Park is too crowded." Both surveys revealed that respondents might not mind hearing others enjoying the park and sharing wilderness experiences, as long as the other visitors are respectful of them and the natural environment. 
Overall, visuals of human subjects seem to have less of a negative impact on wilderness experiences than do hearing human sounds. The follow-up survey showed that seeing negative human behavior has a negative impact on experiences. It should be noted that for the photo exercise, respondents did not photograph people involved in "negative" behavior (i.e., groups calling to each other, children yelling, people on cell phones, etc.) with the exception of just a few photos. It could be hypothesized that the reason photos were not taken of other visitors engaging in questionable behaviors is that there is social desirability to not "police" others or "spy" on people you do not know who are not in your group. Although the photo-log results do not illustrate the potential impact of the sight of "negative" behavior from other visitors, sounds of other voices are viewed as an intrusion of solitude and are indicative that the area is crowded. The follow-up survey clearly reveals that both the sight and sound of "negative" human behaviors are not acceptable or welcomed in wilderness areas.

\section{What does this mean for Park management?}

The findings from both the photo-log and follow-up survey suggest that most visitors come to RMNP for an escape and to see wilderness areas and the beauty and solitude associated with it as essential to their experience. It also became obvious from respondents' self-definition, that the meaning of wilderness experience is a complex idea. For most visitors, being in a wilderness area in RMNP has many meanings. Many of these are feelings or emotions (i.e. "feeling of awe") rather than concrete constructs and therefore harder to describe, but nevertheless important.

Although not a significant part of visitors' definition of wilderness experience in the follow-up survey, pictures from the photo-logs showed that park structures (i.e. trails, bridges, and campsites) and park staff were important in facilitating their wilderness experience. These photos and corresponding photo-log entries indicate that visitors appreciate the National Park Service's effort to preserve land and conserve natural resources while at the same time enabling visitors to fully immerse themselves in the wilderness. Most visitors also seem to be well informed about and support certain Park Service policies and laws already in place (i.e. packing out of trash, not feeding wildlife).

On the other hand, photos of impacts illustrate the need for park managers to monitor certain situations. The two main issues that emerged out of the overall analysis were horse use and the presence of cell phones in wilderness areas. The pictures taken by respondents and the photo-log analysis suggest that horses and horse droppings are viewed as environmentally degrading by many respondents, because it contributes to trail erosion and contamination with horse feces. The photo-log did not prompt people to take pictures of certain subjects or impacts. Instead, respondents were urged to photograph whatever is essential to their wilderness experience (positive or negative). In this respect, horses, especially horse manure, seems to be an important issue to wilderness users.

Although cell phone use was only reported a couple of times within the photo-log entries, the follow-up survey revealed that cell phones have the potential to have a profoundly negative effect on visitors' wilderness experience. Most visitors rated cell phones as greatly detracting to their wilderness experience in the follow-up survey scenario, only surpassed by trash on the ground. Part of the lack of photographs and photo-log entries depicting cell phones might be related to the social desirability of not taking pictures to "police" others, mentioned earlier. Even 
if visitors do not consider cell phones in RMNP a large issue at this point in time, the data collected in this study has the potential to help managers to take proactive steps so that this technology does not become a major detriment to Park wilderness.

At the request of RMNP Wilderness Rangers, the sound of commercial aircraft over-flights was included among the follow-up survey scenarios that measured effect of various changes to the natural environment on wilderness experiences. The response was generally negative to over flights, second only, among introduced sounds, to the negative effects of cell phone use. Verbal descriptions of the impact of over-flights were over three-quarters negative, with none of a straight positive nature. Respondents' neutral responses emphasized that aircraft are part of the $21^{\text {st }}$ century, fly high up above hikers, and the noise momentary in duration; such explanations are indicative that commercial airliners are not that intrusive, in the Park, to some wilderness users. But the ratings and verbal descriptions suggest that over-flights are more negative than neutral, and certainly far more negative than positive.

\section{References}

Peterson, G.L., \& D.W. Lime. 1973. Two sources of bias in measurement of human response to the wilderness environment. Journal of Leisure Research, 24: 240-252.

Taylor, J.G., K.J. Czarnowski, N.R. Sexton, \& S. Flick. 1995. The importance of water to Rocky Mountain National Park Visitors: An adaptation of visitor-employed photography to natural resources management. Journal of Applied Recreation Research 20 (1): 61-85.

Taylor, J.G., N.R. Sexton, \& K.J. Czarnowski. 1995. Visitor employed photography at Rocky Mountain National Park: A valuation technique. Park Science 15 (5): 10-12.

U.S. Department of the Interior. National Park Service. 2001. Rocky Mountain National Park: Backcountry/Wilderness Management Plan and Environmental Assessment. Draft. 


\section{Appendix A}

The Photo-log \& Follow-up Survey

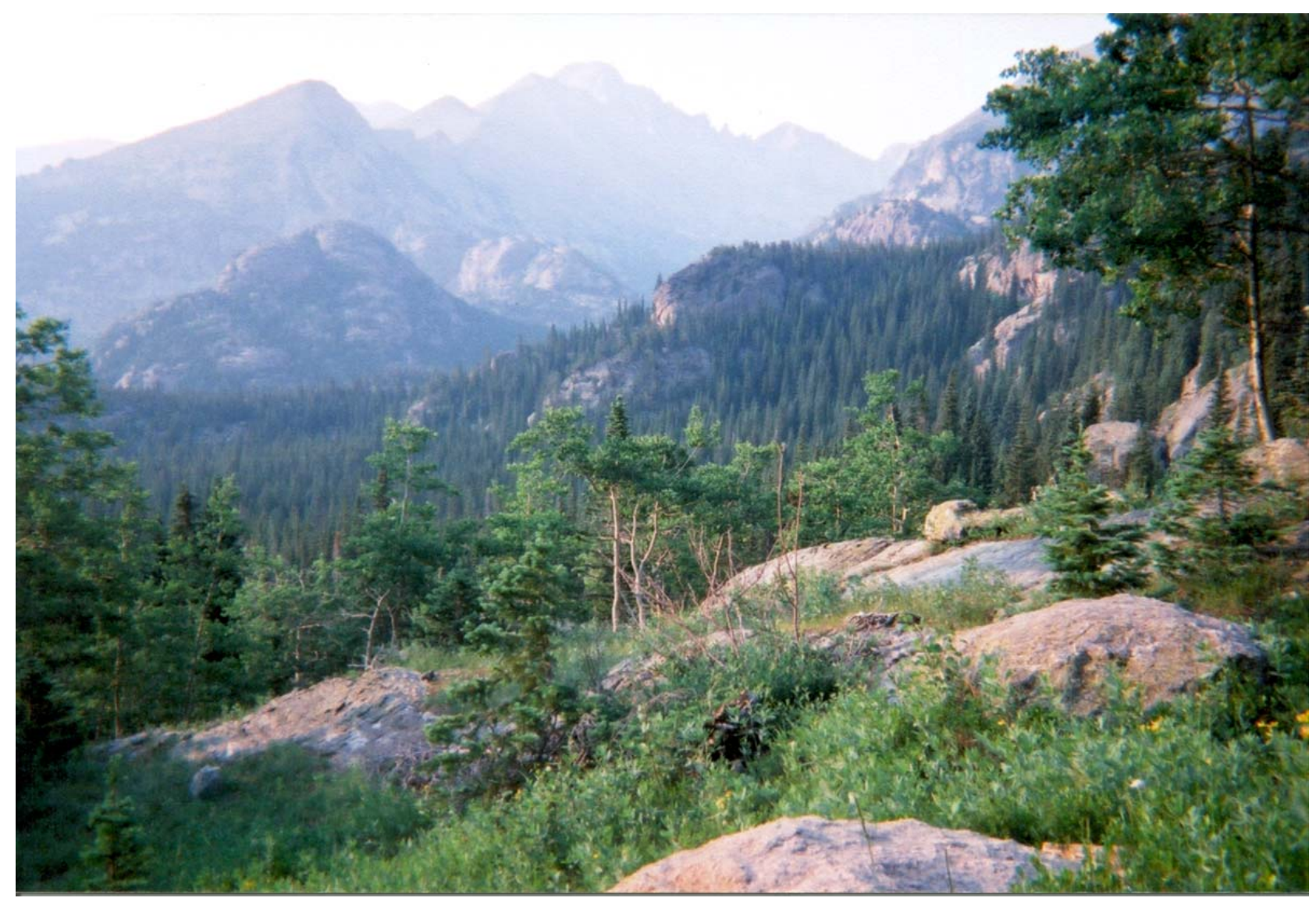




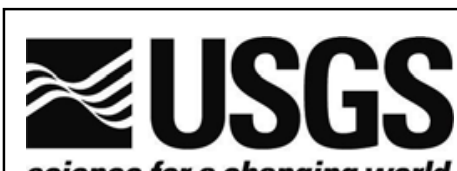

science for a changing world

\section{Wilderness Experience In}

Rocky Mountain National Park 2002

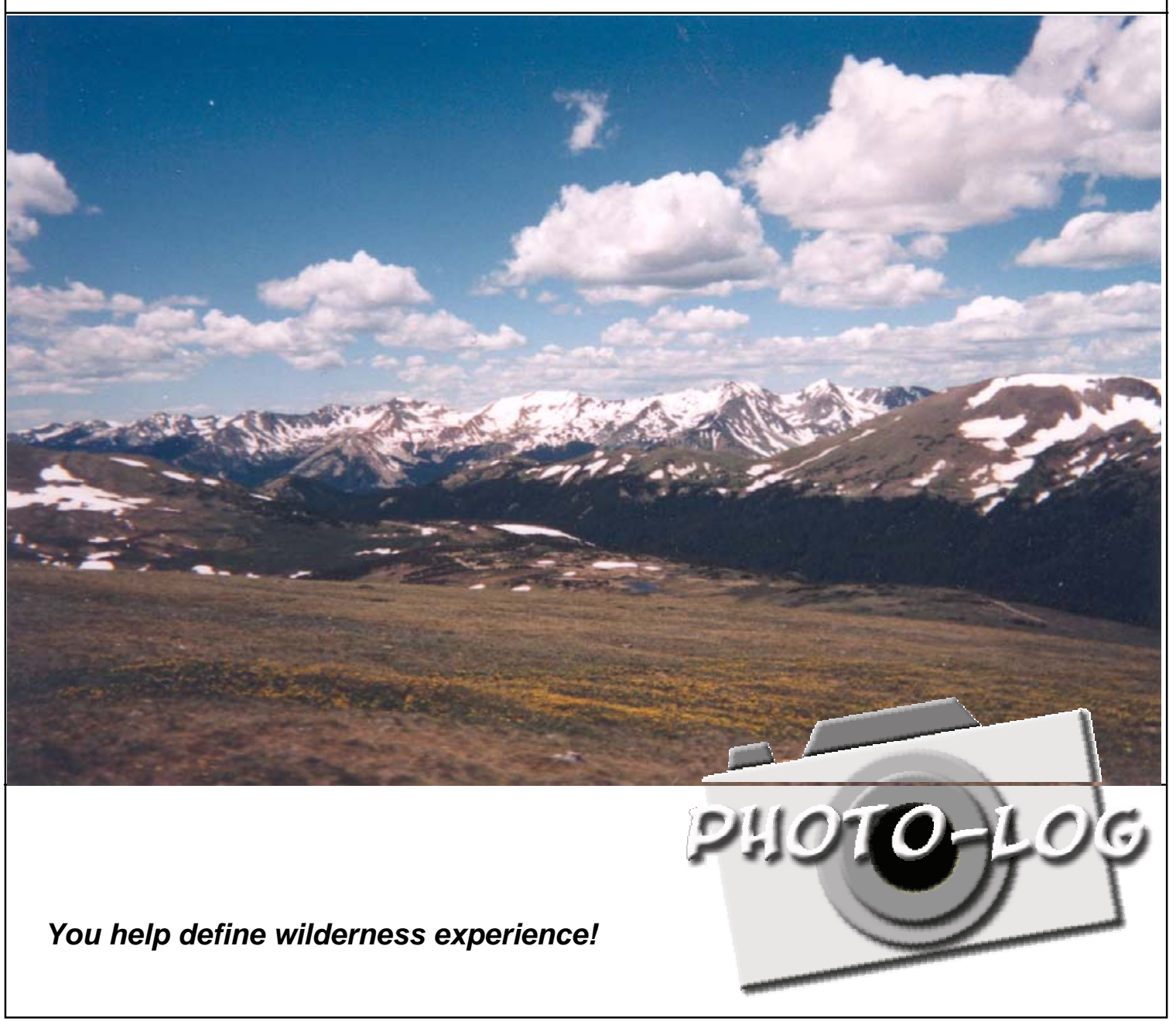


The goal of this study is to learn what features, places or scenes are essential to the quality of wilderness experience in Rocky Mountain National Park. The task you have agreed to do is to capture, on film and in this "photo-log" booklet, those aspects of Rocky Mountain National Park that most affect your wilderness experience. Because you are part of a sample of the larger backcountry user population, your responses are extremely important in order to accurately represent the concerns and preferences of the range of people who recreate in the park. Your participation is voluntary, however; you have the freedom to decide whether you want to take part in this study or not. Please be assured that your answers will be kept strictly confidential. Results of the study will be grouped and presented such that no individual's responses will be identifiable.

\section{Thank you for your valuable contribution to this study!}

Paperwork Reduction Act Statement: A Federal Agency may not conduct or sponsor, and a person is not required to respond to a collection of information unless it displays a currently valid OMB control number. Public reporting burden for this collection of information is estimated to average three minutes per photograph taken or a total of 30 minutes, including the time for reviewing instructions. Send comments regarding this burden estimate or any other aspect of this collection of information, including suggestions for reducing this burden to Department of Agriculture, Clearance Officer, OIRM, Room 404-W, Washington, DC 20250; and to the Office of Management and Budget, Paperwork Reduction Project (OMB \#0596-0108, Expiration date: 01/31/2003), Washington, DC 20503. 


\section{Instructions}

As you take each photograph, please...

1. Record the subject. (What you are taking a picture of.)

2. Record the location. (Where is it in the surrounding countryside?

Identify nearby landmarks, trails, etc. to help pinpoint the location.)

3. Record whether that photo-subject has a positive and/or negative effect on your wilderness experience.

4. Comment briefly on why the subject photographed is important to your experience.

5. Record any sounds that you are particularly aware of.

6. Record whether those sounds have a positive and/or negative effect on your wilderness experience.

7. How do these sounds affect your wilderness experience?

Be sure to record the above information in the booklet in the same order as the pictures in the camera. 


\section{Photo 1}

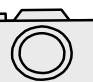

sin

Location: Where is it? Use nearby landmarks, trails, etc. to locate the subject.

Does the subiect of this photoaraph affect vour wilderness experience... positively $\square$ negatively $\square$ both

Explanation: Why is this subject important to your wilderness experience?

Sounds: What sounds are you aware of at this location?

Do these sounds affect your wilderness experience... positively $\square$ negatively $\square$ both

Explanation: How do the sounds you listed affect your wilderness experience? 


\section{Photo 2}

Subject: What are you taking a picture of?

Location: Where is it? Use nearby landmarks, trails, etc. to locate the subject.

Does the subject of this photograph affect your wilderness experience... $\square$ positively $\square$ negatively $\square$ both

Explanation: Why is this subject important to your wilderness experience?

Sounds: What sounds are you aware of at this location?

Do these sounds affect your wilderness experience... positively $\square$ negatively $\square$ both

Explanation: How do the sounds you listed affect your wilderness experience? 


\section{Photo 3}

Subject: What are you taking a picture of?

Location: Where is it? Use nearby landmarks, trails, etc. to locate the subject.

Does the subject of this photograph affect your wilderness experience... $\square$ positively $\square$ negatively $\square$ both

Explanation: Why is this subject important to your wilderness experience?

Sounds: What sounds are you aware of at this location?

Do these sounds affect your wilderness experience... positively $\square$ negatively $\square$ both

Explanation: How do the sounds you listed affect your wilderness experience? 


\section{Photo 4}

Subject: What are you taking a picture of?

Location: Where is it? Use nearby landmarks, trails, etc. to locate the subject.

Does the subject of this photograph affect your wilderness experience... positively $\square$ negatively $\square$ both

Explanation: Why is this subject important to your wilderness experience?

Sounds: What sounds are you aware of at this location?

Do these sounds affect your wilderness experience...

$\square$ positively $\square$ negatively $\square$ both

Explanation: How do the sounds you listed affect your wilderness experience? 


\section{Photo 5}

Subject: What are you taking a picture of?

Location: Where is it? Use nearby landmarks, trails, etc. to locate the subject.

Does the subject of this photograph affect your wilderness experience... positively $\square$ negatively $\square$ both

Explanation: Why is this subject important to your wilderness experience?

Sounds: What sounds are you aware of at this location?

Do these sounds affect your wilderness experience... positively $\square$ negatively $\square$ both

Explanation: How do the sounds you listed affect your wilderness experience? 


\section{Photo 6}

(O) Subject: What are you taking a picture of?

Location: Where is it? Use nearby landmarks, trails, etc. to locate the subject.

Does the subject of this photograph affect your wilderness experience... positively $\square$ negatively $\square$ both

Explanation: Why is this subject important to your wilderness experience?

Sounds: What sounds are you aware of at this location?

Do these sounds affect your wilderness experience... $\square$ positively $\square$ negatively $\square$ both

Explanation: How do the sounds you listed affect your wilderness experience? 


\section{Photo 7}

Subject: What are you taking a picture of?

Location: Where is it? Use nearby landmarks, trails, etc. to locate the subject.

Does the subject of this photograph affect your wilderness experience... positively $\square$ negatively $\square$ both

Explanation: Why is this subject important to your wilderness experience?

Sounds: What sounds are you aware of at this location?

Do these sounds affect your wilderness experience...

$\square$ positively $\square$ negatively $\square$ both

Explanation: How do the sounds you listed affect your wilderness experience? 


\section{Photo 8}

Subject: What are you taking a picture of?

Location: Where is it? Use nearby landmarks, trails, etc. to locate the subject.

Does the subject of this photograph affect your wilderness experience...

$\square$ positively $\square$ negatively $\square$ both

Explanation: Why is this subject important to your wilderness experience?

Sounds: What sounds are you aware of at this location?

Do these sounds affect your wilderness experience...

$\square$ positively $\square$ negatively $\square$ both

Explanation: How do the sounds you listed affect your wilderness experience? 


\section{Photo 9}

Subject: What are you taking a picture of?

Location: Where is it? Use nearby landmarks, trails, etc. to locate the subject.

Does the subject of this photograph affect your wilderness experience... $\square$ positively $\square$ negatively $\square$ both

Explanation: Why is this subject important to your wilderness experience?

Sounds: What sounds are you aware of at this location?

Do these sounds affect vour wilderness experience... positively $\square$ negatively $\square$ both

Explanation: How do the sounds you listed affect your wilderness experience? 


\section{Photo 10}

Subject: What are you taking a picture of?

Location: Where is it? Use nearby landmarks, trails, etc. to locate the subject.

Does the subiect of this photograph affect vour wilderness experience... positively $\square$ negatively $\square$ both

Explanation: Why is this subject important to your wilderness experience?

Sounds: What sounds are you aware of at this location?

Do these sounds affect your wilderness experience... positively $\square$ negatively $\square$ both

Explanation: How do the sounds you listed affect your wilderness experience? 
After we receive your camera and develop the film, we will send you a full set of the color prints you have taken and a copy of your photo-log booklet. At that time, you will also receive a short follow-up survey asking you a few questions about yourself (i.e., age, gender, etc.), your wilderness experience in Rocky Mountain National Park, and about some of the photos you took. To send you your photos and this survey, we will need your name and mailing address.

Name

Street address

City

State

Zip code 
Before leaving the park, please drop your camera and photo-log in one of the drop boxes located at the entrance stations, visitor centers, or the Wild Basin and Longs Peak Ranger stations.

If you forgot to drop off the camera and photo-log, please mail them to:

Camera Survey

U.S. Geological Survey

2150 Centre Avenue Bldg. C

Fort Collins, Colorado 80526-8118

If you have additional questions or comments, please contact:

Jonathan Taylor, Project Leader (970) 226-9438 or jonathan_taylor@usgs.gov Elke Schuster, Project Assistant (970) 226-9333 or elke_schuster@usgs.gov

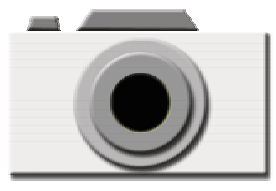




\section{Wilderness Experience In}

\section{Rocky Mountain National Park 2002}

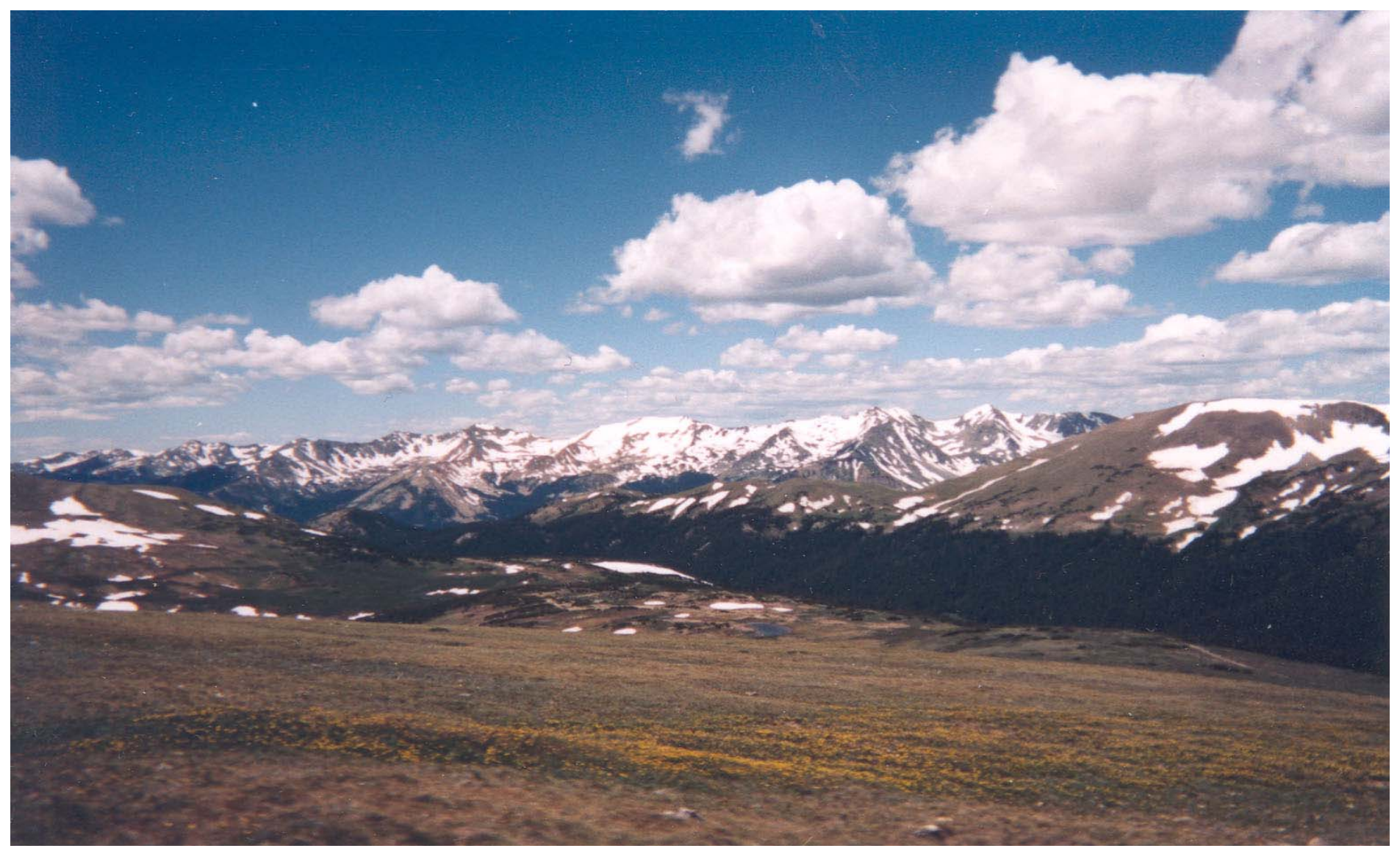

Paperwork Reduction Act Statement: A Federal Agency may not conduct or sponsor, and a person is not required to respond to a collection of information unless it displays a currently valid OMB control number. Public reporting burden for this collection of information is estimated to average a total of 15 minutes, including the time for reviewing instructions. Send comments regarding this burden estimate or any other aspect of this collection of information, including suggestions for reducing this burden to Department of Agriculture, Clearance Officer, OIRM, Room 404-W, Washington, DC 20250; and to the Office of Management and Budget, Paperwork Reductions Project (OMB \#05960108, Expiration Date: 01/31/2003), Washington, DC 20503. 
The goal of this study is to learn what features and places are essential to the quality of your wilderness experience in Rocky Mountain National Park. We are also interested in learning more about the emotions you are aware of while visiting the park. You have already captured, on film and in a "photo-log " booklet, the aspects of the park that most affected your wilderness experience on the trip you took this past summer. For this mail survey, we would like you to answer a few questions about the photos you took. Your responses are extremely important in order to accurately represent the concerns \& preferences of the range of people who recreate in the park. Please be assured that your answers will be kept strictly confidential.

\section{SECTION I.}

First, we would like to ask you some questions about your visit to Rocky Mountain National Park [RMNP]. We are asking specifically about the visit when we gave you the camera and about the photos that you took. Please follow the instructions after each question.

1. Please tell us which one of your photographed places was most important to your Backcountry/Wilderness experience that day. Please notice that your photos are numbered on the backside. List the number and a brief description of that photo/place in the space below.

2. Are there other places in RMNP that are especially important to you that were not visited during the trip when you took these pictures? Please list them in the space below.

3. Which of the reasons listed below was most important for your visit to RMNP on this trip?

\section{Please mark only one answer.}

I came here because I enjoy the Backcountry/Wilderness itself.

I came here because I wanted to spend more time with my family/companions.

I came here to gain a fresh perspective on life.

I came here because it is a good place to do some of the activities that I enjoy.

4. When you visit RMNP, do you consider yourself to be in the wilderness? Please check only one.

Yes

No

It depends where I am in the park.

5. In your own words, would you please describe what the experience of being in the Backcountry/Wilderness at RMNP means to you? Please write in the space below. 


\section{SECTION II.}

For this section we would like to ask you a few questions about TWO of the photographs that you took while at Rocky Mountain National Park [RMNP]. We have enclosed a couple of pages with corresponding numbers from your photo-log to help you remember these places.

Please follow the instructions after each question.

6. Please find Photo Number in your set of RMNP Photographs (the photo number is listed on the back) and read the corresponding page from your photo log. Having read what you said about the sights and sounds of that place, please consider how each of the following changes would affect your experience:

Please indicate, on the scales below, how much each change would enhance or detract from your experience at this place.

Change A: You hear a commercial jet aircraft flying overhead.

GREATLY

DETRACTS

1

\section{2}

Describe how this change alters your experience:

(Circle the most appropriate number.)

$\begin{array}{llllll}3 & 4 & 5 & 6 & 7 & 8\end{array}$

GREATLY

ENHANCES

Change B: You hear a bird singing.

GREATLY

DETRACTS

1

(Circle the most appropriate number.)

4

23

5

6

7

8

Describe how this change alters your experience:

Change C: You hear a person talking on their cell phone.

GREATLY

DETRACTS

12

(Circle the most appropriate number.)

$\begin{array}{lllll}3 & 4 & 5 & 6 & 7\end{array}$

8

910 
7. Please find Photo Number in your set of RMNP Photographs (the photo number is listed on the back) and read the corresponding page from your photo log. Having read what you said about the sights and sounds of that place, please consider how each of the following changes would affect your experience.

Please indicate, on the scales below, how much each change would enhance or detract from your experience at this place.

Change A1: You see a bull elk walk into sight, about 50 yards away.

GREATLY

DETRACTS

1 $\begin{array}{llll}\text { (Circle the most appropriate } & \text { number.) }\end{array}$
GREATLY

ENHANCES

Describe how this change alters your experience:

Change A2: Looking more closely, you see that the elk is wearing a radio collar.

GREATLY

DETRACTS

1
(Circle the most appropriate number.)

$3 \quad 4 \quad 5 \quad 6$

6

7

89

GREATLY

ENHANCES

10

Describe how this change alters your experience:

Change B: You see a group of about 5 people walk into sight, about 50 yards away.

GREATLY

DETRACTS

1
(Circle the most appropriate number.)

$\begin{array}{lllll}3 & 4 & 5 & 6 & 7\end{array}$

8

89

GREATLY

ENHANCES

10

Describe how this change alters your experience:

Change C: You see a family feeding part of their lunch to a chipmunk.

GREATLY

DETRACTS 1

2

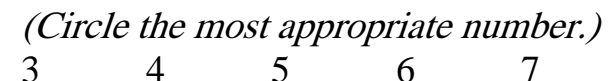

9

(1)




\section{SECTION II.}

For this section we would like to ask you a few questions about TWO of the photographs that you took while at Rocky Mountain National Park [RMNP]. We have enclosed a couple of pages with corresponding numbers from your photo-log to help you remember these places.

Please follow the instructions after each question.

6. Please find Photo Number in your set of RMNP Photographs (the photo number is listed on the back) and read the corresponding page from your photo log. Having read what you said about the sights and sounds of that place, please consider how each of the following changes would affect your experience:

Please indicate, on the scales below, how much each change would enhance or detract from your experience at this place.

Change A: You hear several approaching hikers calling to each other.

GREATLY

DETRACTS

(1)

2
(Circle the most appropriate number.)

$\begin{array}{llllll}3 & 4 & 5 & 6 & 7 & 8\end{array}$

89

GREATLY

ENHANCES

10

Describe how this change alters your experience:

Change B: You hear thunder from a storm about a mile away.

GREATLY

DETRACTS

1

(Circle the most appropriate number.)

2

3

4

5

6

7

8

9

GREATLY

ENHANCES

Describe how this change alters your experience:

Change C: You hear children laughing.

GREATLY

DETRACTS

12

(Circle the most appropriate number.)

$\begin{array}{lllll}3 & 4 & 5 & 6 & 7\end{array}$

8

89

GREATLY

ENHANCES

10

Describe how this change alters your experience: 
7. Please find Photo Number in your set of RMNP Photographs (the photo number is listed on the back) and read the corresponding page from your photo log. Having read what you said about the sights and sounds of that place, please consider how each of the following changes would affect your experience.

Please indicate, on the scales below, how much each change would enhance or detract from your experience at this place.

Change A: You see scientific weather-monitoring equipment inside a fenced-off area.

GREATLY

DETRACTS 1

2

(Circle the most appropriate number.)

$3 \quad 4 \quad 5$

6

7

8

GREATLY

ENHANCES

10

Describe how this change alters your experience:

Change B: You see thrown away drink containers on the ground.

GREATLY

DETRACTS

1
(Circle the most appropriate number.)

$\begin{array}{lllll}3 & 4 & 5 & 6 & 7\end{array}$

$2 \quad 3$

your

Describe how this change alters your experience:

Change C: You see a fly fisherman casting into a nearby stream.

GREATLY

DETRACTS

12

(Circle the most appropriate number.)

$\begin{array}{llllll}3 & 4 & 5 & 6 & 7 & 8\end{array}$

GREATLY

ENHANCES

10

Describe how this change alters your experience: 


\section{SECTION III.}

8. Visitors to RMNP have talked about experiencing certain feelings and emotions during their visits. To what extent do you agree or disagree that you personally experience the following when you visit the Backcountry/Wilderness at RMNP? Circle the number that best represents your response.

\begin{tabular}{|llccccc} 
& & Strongly & Disagree & Disagree & Neutral & $\begin{array}{c}\text { Strongly } \\
\text { Agree }\end{array}$ \\
\hline A. & I feel awe inspired & 1 & 2 & 3 & 4 & 5 \\
\hline B. & I feel slowed down/relaxed & 1 & 2 & 3 & 4 & 5 \\
\hline C. & I feel socially connected with my companions & 1 & 2 & 3 & 4 & 5 \\
\hline D. & I feel conscious of the creation of God & 1 & 2 & 3 & 4 & 5 \\
\hline E. & I feel joy/happiness & 1 & 2 & 3 & 4 & 5 \\
\hline F. & I feel respect for the wilderness & 1 & 2 & 3 & 4 & 5 \\
\hline G. & I feel rejuvenated & 1 & 2 & 3 & 4 & 5 \\
\hline H. & I feel problem free & 1 & 2 & 3 & 4 & 5 \\
\hline I. & I feel personally connected to the wilderness & 1 & 2 & 3 & 4 & 5 \\
\hline J. & I feel peaceful & 1 & 2 & 3 & 4 & 5 \\
K. & I feel anxiety/nervousness & 1 & 2 & 3 & 4 & 5 \\
\hline L. & I feel connected to my own spirituality & 1 & 2 & 3 & 4 & 5 \\
\hline
\end{tabular}

Please list your other feelings while visiting Backcountry/Wilderness at RMNP that do not appear on this list?

Please write in the space below.

9. To what extent do you agree or disagree with each of the following statements about RMNP? Please circle the number that best reDresents vour resDonse.

\begin{tabular}{|c|c|c|c|c|c|}
\hline Statement & $\begin{array}{l}\text { Strongly } \\
\text { Disagree }\end{array}$ & Disagree & Neutral & Agree & $\begin{array}{l}\text { Strongly } \\
\text { Agree }\end{array}$ \\
\hline A. I mainly come to this place to enjoy the Backcountry/Wilderness. & 1 & 2 & 3 & 4 & 5 \\
\hline B. RMNP is very special to me. & 1 & 2 & 3 & 4 & 5 \\
\hline C. This place brings back memories of time spent with friends. & 1 & 2 & 3 & 4 & 5 \\
\hline D. I get more satisfaction out of visiting RMNP than any other place. & 1 & 2 & 3 & 4 & 5 \\
\hline $\begin{array}{l}\text { E. Most of the activities that I do here are related to the } \\
\text { Backcountry/Wilderness. }\end{array}$ & 1 & 2 & 3 & 4 & 5 \\
\hline F. I am very attached to RMNP. & 1 & 2 & 3 & 4 & 5 \\
\hline G. I associate special people in my life with this place. & 1 & 2 & 3 & 4 & 5 \\
\hline $\begin{array}{l}\text { H. Doing what I do at RMNP is more important to me than doing it in } \\
\text { any other place. }\end{array}$ & 1 & 2 & 3 & 4 & 5 \\
\hline $\begin{array}{l}\text { I. Being in the Backcountry/Wilderness is necessary for me to do the } \\
\text { things that I enjoy. }\end{array}$ & 1 & 2 & 3 & 4 & 5 \\
\hline J. RMNP means a lot to me. & 1 & 2 & 3 & 4 & 5 \\
\hline K. My family regularly visited RMNP when I was young. & 1 & 2 & 3 & 4 & 5 \\
\hline $\begin{array}{l}\text { L. I wouldn't substitute any other area for doing the types of things } \\
\text { that I do at RMNP }\end{array}$ & 1 & 2 & 3 & 4 & 5 \\
\hline
\end{tabular}




\section{Listed below are statements that represent different ways people feel about the environment and}

environmental issues. Please indicate the extent to which you personally agree or disagree with each statement. Circle the number that best represents your response.

\begin{tabular}{|c|c|c|c|c|c|}
\hline Statement & $\begin{array}{l}\text { Strongly } \\
\text { Disagree }\end{array}$ & Disagree & Neither & Agree & $\begin{array}{c}\text { Strongly } \\
\text { Agree }\end{array}$ \\
\hline $\begin{array}{l}\text { A. Present levels of industrial activity are } \\
\text { severely upsetting the natural environment. }\end{array}$ & 1 & 2 & 3 & 4 & 5 \\
\hline $\begin{array}{l}\text { B. Humans have the right to alter nature to } \\
\text { satisfy wants and desires. }\end{array}$ & 1 & 2 & 3 & 4 & 5 \\
\hline C. There are limits to industrial growth. & 1 & 2 & 3 & 4 & 5 \\
\hline $\begin{array}{l}\text { D. The natural environment has value within } \\
\text { itself regardless of any value that humans } \\
\text { may place on it. }\end{array}$ & 1 & 2 & 3 & 4 & 5 \\
\hline $\begin{array}{l}\text { E. Maintaining economic growth is more } \\
\text { important than protecting the natural } \\
\text { environment. }\end{array}$ & 1 & 2 & 3 & 4 & 5 \\
\hline $\begin{array}{l}\text { F. Natural resources should be used primarily } \\
\text { to provide for basic needs rather than } \\
\text { material wealth. }\end{array}$ & 1 & 2 & 3 & 4 & 5 \\
\hline $\begin{array}{l}\text { G. Humans have moral duties and obligations } \\
\text { to other animal species. }\end{array}$ & 1 & 2 & 3 & 4 & 5 \\
\hline $\begin{array}{l}\text { H. A change in basic attitudes is necessary to } \\
\text { solve environmental problems. }\end{array}$ & 1 & 2 & 3 & 4 & 5 \\
\hline $\begin{array}{l}\text { I. Humans have the right to subdue and } \\
\text { control the rest of nature. }\end{array}$ & 1 & 2 & 3 & 4 & 5 \\
\hline $\begin{array}{l}\text { J. Humans have moral duties and obligations } \\
\text { to plants and trees. }\end{array}$ & 1 & 2 & 3 & 4 & 5 \\
\hline $\begin{array}{l}\text { K. Present generations of humans have moral } \\
\text { duties and obligations to future human } \\
\text { generations. }\end{array}$ & 1 & 2 & 3 & 4 & 5 \\
\hline $\begin{array}{l}\text { L. Humans should have compassion and } \\
\text { respect for the rest of nature. }\end{array}$ & 1 & 2 & 3 & 4 & 5 \\
\hline
\end{tabular}




\section{SECTION IV.}

Finally, we would like to ask you to tell us a bit about your previous experience in Rocky Mountain National Park (RMNP) and your background. Again, this information will remain confidential.

Please follow the instructions given for each question.

11. How many times have you visited RMNP before this trip?
A. \# Visits to Backcountry/Wilderness
B. \# Visits to developed front country

12. How many years ago did you first visit RMNP? \# Years

13. Including this current visit, how many times did you visit RMNP in the past 12 months?
A. \# Visits to Backcountry/Wilderness
B. \# Visits to developed front country

14. Approximately how many other Backcountry/Wilderness areas have you visited in the past? \# Areas

15. On this scale, please indicate how familiar you are with RMNP? Please circle one number.

$\begin{array}{llllllllll}1 & 2 & 3 & 4 & 5 & 6 & 7 & 8 & 9 & 10\end{array}$

Not at all

Extremely

familiar familiar

16. On this scale, please indicate how attached you are to RMNP? Please circle one number.

$\begin{array}{llllllllll}1 & 2 & 3 & 4 & 5 & 6 & 7 & 8 & 9 & 10\end{array}$

Not at all

Extremely attached attached

17. Do you belong to any organizations that are primarily concerned with environmental protection? No Yes If so, please list them

18. Do you belong to any organizations that are primarily concerned with hunting, angling, or forestry? No Yes If so, please list them

19. Are you: Male Female 
21. In which of the following kinds of places did you spend the most time while growing up (to age 18)?

Please mark only one answer.

On a farm or ranch

Rural or small town (under 1,000 population)

Town (1,000 to 5,000 population)
Small city (5,000 to 50,000 population)

Medium city (50,000 to 1 million population)

In a metropolitan area (over 1 million people)

22. What is the highest level of education you have attained? Please circle one.

Elementary School

Less than 8

23. Are you still a student?
College

$13 \quad 14 \quad 15 \quad 16$
Graduate or Professional

More than 16

24. Which of the following categories best describes your annual household income, before taxes?

Less than $\$ 5,000$

$\$ 5,000$ to 9,999

$\$ 10,000$ to 14,999

$\$ 15,000$ to 19,999

$\$ 20,000$ to 24,999
$\$ 25,000$ to 34,999

$\$ 35,000$ to 49,999

$\$ 50,000$ to 74,999

$\$ 75,000$ to 100,000

Over $\$ 100,000$

25. How many people within your household actively contribute to this income? \#

People

We at the National Park Service, the U. S. Geological Service, and Colorado State University thank you for your time. You have helped us to learn more about the experience of those who visit Rocky Mountain National Park. We welcome any additional input or comments from you about how park staff can improve the management of Backcountry/Wilderness at RMNP. You may receive a copy of the results of this study by writing "copy of results requested" on the back of the return envelope, and printing your name and address below it. Please do not put this information on the survey itself.

Please feel free to write any additional comments below: 


\section{Appendix B}

The Sampling Plan

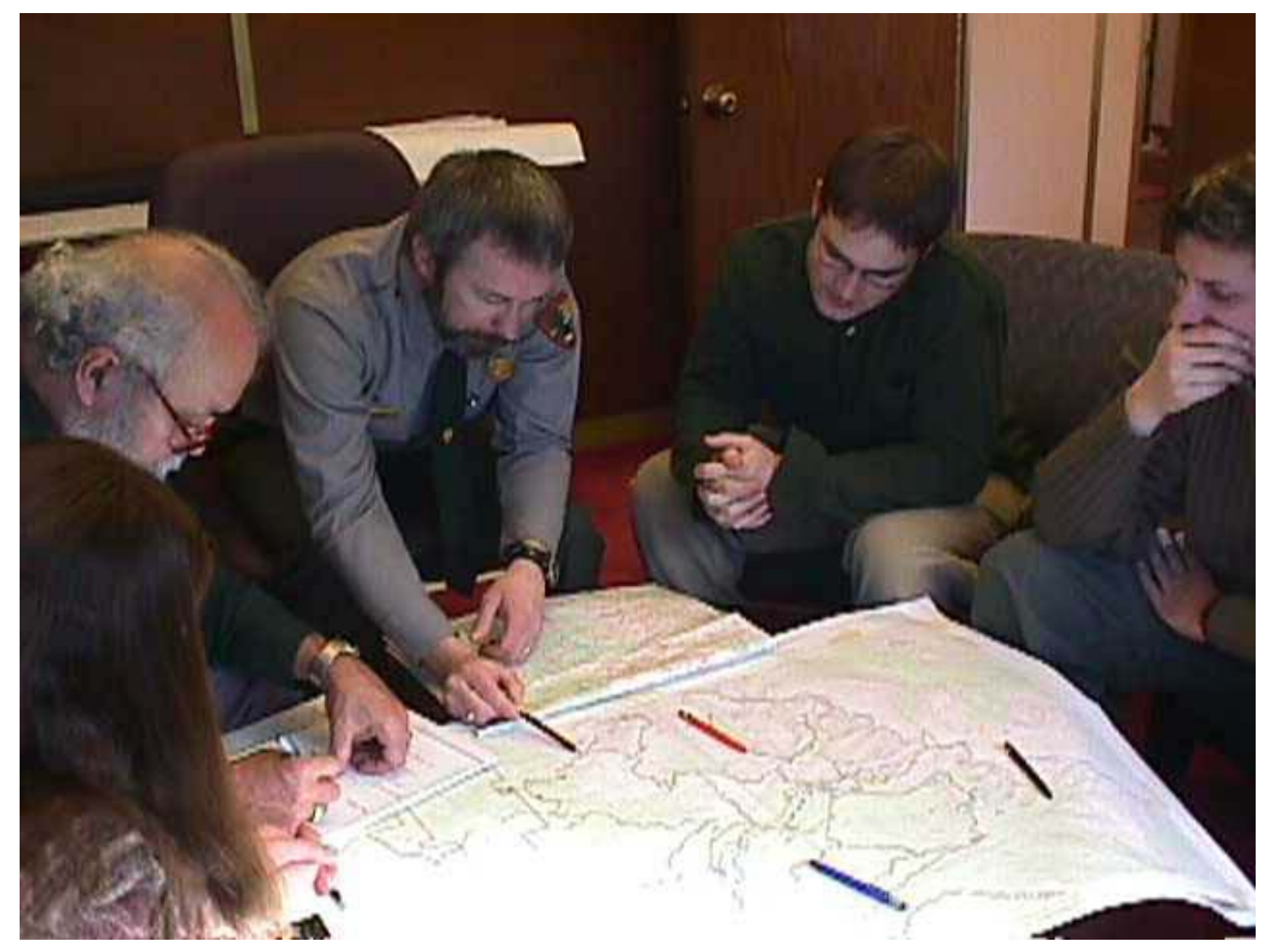




\section{$\underline{\text { Sampling Plan }}$}

Initial Distribution of 300 Cameras:

200 - Day Hikers

100 - Backcountry Overnight Users

Coverage will combine use rate estimates from Backcountry Rangers with the necessity to cover all use areas desired by Park staff.

Day hiker and Backcountry user sampling will be done at designated trailheads.

» Morning sampling to capture hikers on their way out into the backcountry

» Sampling at each trailhead will be divided proportionally between

$\circ$ Weekend hikers (Fri-Sun): $60 \%$ $+4^{\text {th }}$ of July

○ Weekday hikers (Mo-Thu): $40 \%$

॥ Sampling will roughly mimic proportional patterns of day hike and overnight use

Four general use areas were identified for Day Hike and Backcountry use assessments:

- Wild Basin, including Longs Peak and Twin Sisters

- Bear Lake trails and Moraine Park area

- West park trails

○ North park trails

The specific trailheads identified are these:

Wild Basin Area (4):

○ Wild Basin trailhead

- Longs Peak trailhead

- Sandbeach Lake trailhead

- Twin Sisters trailhead

Bear Lake / Moraine Park Area (5):

- Bear Lake trailhead 1

- Bear Lake trailhead 2

- Glacier Gorge trailhead

- Fern Lake trailhead

- Cub Lake trailhead

West Park Area (7):

- East Inlet trailhead

- Green Mountain trailhead

- Onahu Creek trailhead

- Timber Lake trailhead

- Colorado River trailhead

- North Inlet trailhead

- Tonahutu trailhead

North Park Area (5):

- Lawn Lake trailhead

- Deer Ridge trailhead

- Twin Owls trailhead

- Corral Creek trailhead

- Cow Creek trailhead

(to Nymph, Dream and Emerald Lake)

(to Bierstadt Lake or Flattop Mountain) (to Gem Lake or Lumpy Ridge - climbers)

(excluding Big South Trail - U.S.F.S.) 
Proportional distribution of cameras and photo-logs (Day Hikers)

$\begin{array}{llll}\text { I. Bear Lake Area } & 35 \% & = & 70 \text { cameras } \\ \text { II. Wild Basin } & 25 \% & = & 50 \text { cameras } \\ \text { III. Rest of Part } & 40 \% & = & \text { 80 cameras } \\ & & & 200 \text { cameras }\end{array}$

Distribution among sub-areas of the Park (Day Hikers)

\begin{tabular}{|c|c|c|c|c|}
\hline $\begin{array}{c}\text { Bear Lake area: } \\
\text { (70) }\end{array}$ & $\begin{array}{l}\text { Bear Lake trails (3) } \\
\text { Moraine Park trails (2) }\end{array}$ & $\begin{array}{l}65 \% \\
35 \%\end{array}$ & $\begin{array}{l}= \\
=\end{array}$ & $\begin{array}{l}46 \text { cameras } \\
24 \text { cameras }\end{array}$ \\
\hline \multicolumn{5}{|c|}{ Wild Basin / Longs Peak : } \\
\hline \multirow[t]{3}{*}{$(50)$} & Wild Basin trail (1) & $56 \%$ & $=$ & 28 cameras \\
\hline & Longs Peak (1) & $38 \%$ & $=$ & 19 cameras \\
\hline & Sand Beach trail (1) & $6 \%$ & $=$ & 3 cameras \\
\hline \multirow{3}{*}{$\begin{array}{r}\text { Rest of Park: } \\
(80)\end{array}$} & Cow and Corral Creek & @ 3 & $=$ & 6 cameras \\
\hline & $\begin{array}{l}\text { Twin Sisters, } \\
\text { Twin Owls, }\end{array}$ & @6 6 & $=$ & 18 cameras \\
\hline & $\begin{array}{l}\text { Tonahutu trailheads } \\
\text { Remaining } 8 \text { trailheads }\end{array}$ & $@ 7$ & $=$ & 56 cameras \\
\hline
\end{tabular}

Proportional distribution of cameras and photo-logs (Backcountry Users)

$\begin{array}{llll}\text { I. Bear Lake Area } & 35 \% & = & 35 \text { cameras } \\ \text { II. Wild Basin } & 25 \% & = & 25 \text { cameras } \\ \text { III. Rest of Part } & 40 \% & = & 40 \text { cameras } \\ & & & 100 \text { cameras }\end{array}$

\begin{tabular}{|c|c|c|c|c|}
\hline \multicolumn{5}{|c|}{ Distribution among sub-areas of the Park (Backcountry Users) } \\
\hline \multirow{2}{*}{$\begin{array}{c}\text { Bear Lake area: } \\
\qquad(35)\end{array}$} & Bear Lake trails (3) & $65 \%$ & $=$ & 23 cameras \\
\hline & Moraine Park trails (2) & $35 \%$ & $=$ & 12 cameras \\
\hline \multicolumn{5}{|c|}{ Wild Basin / Longs Peak : } \\
\hline \multirow[t]{3}{*}{$(25)$} & Wild Basin trail (1) & $56 \%$ & $=$ & 14 cameras \\
\hline & Longs Peak (1) & $38 \%$ & $=$ & 10 cameras \\
\hline & Sand Beach trail (1) & $6 \%$ & $=$ & 1 camera \\
\hline \multirow[t]{3}{*}{$\begin{array}{r}\text { Rest of Park: } \\
(40)\end{array}$} & Cow and Corral Creek & \multicolumn{2}{|c|}{ @ $2(1 \mathrm{x})$} & 3 cameras \\
\hline & $\begin{array}{l}\text { Twin Sisters, } \\
\text { Twin Owls, } \\
\text { Tonahutu trailheads }\end{array}$ & \multicolumn{2}{|l|}{ (a) 3} & 9 cameras \\
\hline & Remaining 8 trailheads & \multicolumn{2}{|c|}{ @ 4 (4x) } & 28 cameras \\
\hline
\end{tabular}

Note: The original sampling plan was modified during the study to include two additional trailheads (Dunraven - North Fork in the North Park area and Finch Lake in the Wild Basin area) to more accurately reflect backcountry use. Due to difficulties handing out the cameras at trailheads, approximately 20 overnight use cameras were handed out at the backcountry permit office towards the end of the study. 


\title{
Appendix C
}

\author{
Photo-log Results
}

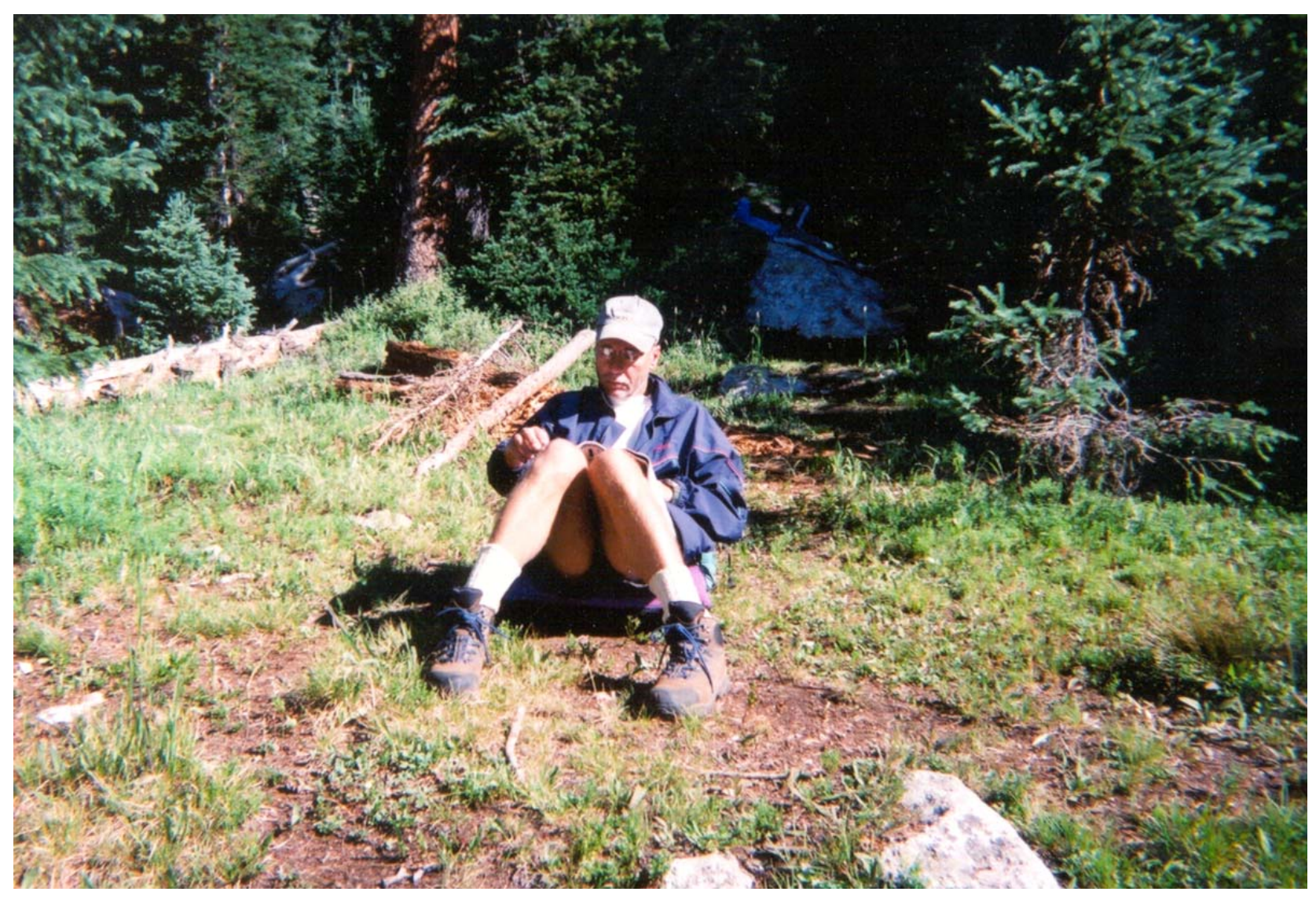


Table C-1. Count totals and percentages that include natural subject photos $(n=254$ respondents).

\begin{tabular}{|c|c|c|c|c|}
\hline Nature subject & $\begin{array}{c}\text { Number of } \\
\text { people who } \\
\text { took a photo } \\
\text { of this subject }\end{array}$ & $\begin{array}{l}\text { Percent of } \\
\text { all people } \\
\text { who took a } \\
\text { photo of } \\
\text { this subject }\end{array}$ & $\begin{array}{l}\text { Number of } \\
\text { photos that } \\
\text { include this } \\
\text { subject }^{2}\end{array}$ & $\begin{array}{c}\text { Percent of all } \\
\text { natural subject } \\
\text { photographs }\end{array}$ \\
\hline Lake/Pond & 116 & 46 & 186 & 9 \\
\hline Wildlife & 114 & 45 & 195 & 10 \\
\hline River/Creek/Stream & 108 & 43 & 135 & 7 \\
\hline Mountains/Peaks/Glaciers & 107 & 42 & 193 & 10 \\
\hline Tree and River & 107 & 42 & 193 & 10 \\
\hline Waterfall & 97 & 38 & 141 & 7 \\
\hline Trees/Logs & 80 & 31 & 122 & 6 \\
\hline Rocks/Cliffs/Boulders & 80 & 31 & 112 & 6 \\
\hline Wildflowers & 67 & 26 & 82 & 4 \\
\hline View/Scenic Vista/Open Space & 54 & 21 & 67 & 3 \\
\hline Meadows/Valleys & 52 & 20 & 61 & 3 \\
\hline Mountain and Lake & 45 & 18 & 60 & 3 \\
\hline Forest Fire/Burn Area & 21 & 8 & 24 & 1 \\
\hline Rock and Trees & 18 & 7 & 19 & 1 \\
\hline Stream and Wildflowers & 16 & 6 & 18 & 1 \\
\hline Mountains and Clouds & 15 & 6 & 15 & 1 \\
\hline Mountain and Meadow & 13 & 5 & 13 & 1 \\
\hline Weather and Mountain & 12 & 5 & 12 & 1 \\
\hline Sun/Moon/Stars & 11 & 4 & 12 & 1 \\
\hline Mountain and Trees & 11 & 4 & 11 & 1 \\
\hline Stream and Waterfall & 11 & 4 & 11 & 1 \\
\hline Wildlife and Lake & 10 & 4 & 10 & 1 \\
\hline Incline/Slope/Pass/Backdrop & 9 & 4 & 9 & 1 \\
\hline Rock and Wildflowers & 9 & 4 & 11 & 1 \\
\hline Wildflowers and Meadow & 9 & 4 & 9 & 1 \\
\hline Mountains and Stream & 9 & 4 & 13 & 1 \\
\hline River and Rock & 8 & 3 & 8 & 1 \\
\hline Wildlife and Rock & 8 & 3 & 10 & 1 \\
\hline Wildlife and Stream & 8 & 3 & 8 & $<1$ \\
\hline Weather (Snow/Hail/Rain) & 7 & 3 & 7 & $<1$ \\
\hline Rock and Mountain & 7 & 3 & 7 & $<1$ \\
\hline Wildlife and Meadow & 7 & 3 & 8 & $<1$ \\
\hline Clouds/Sky & 6 & 2 & 6 & $<1$ \\
\hline Tundra & 6 & 2 & 8 & $<1$ \\
\hline Stream and Meadow & 6 & 2 & 7 & $<1$ \\
\hline Wildlife and Trees & 6 & 2 & 6 & $<1$ \\
\hline Rocks and Vegetation & 6 & 2 & 6 & $<1$ \\
\hline Lake and Rocks & 6 & 2 & 6 & $<1$ \\
\hline Lake and Sun/Moon/Stars & 6 & 2 & 7 & $<1$ \\
\hline Sun and Trees & 6 & 2 & 7 & $<1$ \\
\hline Meadow and Lake & 5 & 2 & 6 & $<1$ \\
\hline
\end{tabular}


Table C-1. (Continued) Count totals and percentages that include natural subject photos

\begin{tabular}{|c|c|c|c|c|}
\hline Nature Subject & \# of people & $\%$ of people & \# of photos & $\%$ of photos \\
\hline Lake and Waterfall & 5 & 2 & 5 & $<1$ \\
\hline Wildflowers and Lake & 5 & 2 & 5 & $<1$ \\
\hline Lake and Trees & 5 & 2 & 5 & $<1$ \\
\hline Valley and Trees & 4 & 2 & 4 & $<1$ \\
\hline Mountain and Sun & 4 & 2 & 4 & $<1$ \\
\hline Trees and Other Vegetation & 4 & 2 & 4 & $<1$ \\
\hline Wildflowers and Trees & 4 & 2 & 4 & $<1$ \\
\hline Wildflowers and Wildlife & 4 & 2 & 4 & $<1$ \\
\hline Lake and Weather & 4 & 2 & 4 & $<1$ \\
\hline Canyon/Gorge & 3 & 1 & 3 & $<1$ \\
\hline Mountain and Wildflowers & 3 & 1 & 3 & $<1$ \\
\hline Rocks and Clouds & 3 & 1 & 3 & $<1$ \\
\hline Clouds and Lake & 3 & 1 & 3 & $<1$ \\
\hline Mountain and Canyon & 3 & 1 & 3 & $<1$ \\
\hline Waterfall and Rocks & 3 & 1 & 3 & $<1$ \\
\hline Rock and Backdrop & 2 & $<1$ & 2 & $<1$ \\
\hline Stream and Grass & 2 & $<1$ & 2 & $<1$ \\
\hline Meadow and Sun & 2 & $<1$ & 2 & $<1$ \\
\hline Sun and Stream & 2 & $<1$ & 2 & $<1$ \\
\hline Wildflowers and Grass & 2 & $<1$ & 2 & $<1$ \\
\hline Forest Fire and Valley & 2 & $<1$ & 2 & $<1$ \\
\hline Forest Fire and Mountain & 2 & $<1$ & 2 & $<1$ \\
\hline Forest Fire and Trees & 2 & $<1$ & 2 & $<1$ \\
\hline Trees and Sky & 2 & $<1$ & 2 & $<1$ \\
\hline Wildflowers and Forest & 2 & $<1$ & 2 & $<1$ \\
\hline Waterfall and Wildflowers & 2 & $<1$ & 2 & $<1$ \\
\hline Canyon and Trees & 1 & $<1$ & 1 & $<1$ \\
\hline Trees and Grass & 1 & $<1$ & 1 & $<1$ \\
\hline Tundra and Wildflowers & 1 & $<1$ & 1 & $<1$ \\
\hline Mountain and Grass & 1 & $<1$ & 1 & $<1$ \\
\hline Stream and Other Vegetation & 1 & $<1$ & 1 & $<1$ \\
\hline Water and Burn Area & 1 & $<1$ & 1 & $<1$ \\
\hline Sun and Clouds & 1 & $<1$ & 1 & $<1$ \\
\hline Canyon and Meadow & 1 & $<1$ & 1 & $<1$ \\
\hline Clouds and View & 1 & $<1$ & 1 & $<1$ \\
\hline Weather and Trees & 1 & $<1$ & 1 & $<1$ \\
\hline Sun and Waterfall & 1 & $<1$ & 1 & $<1$ \\
\hline Mountains and Tundra & 1 & $<1$ & 1 & $<1$ \\
\hline Sun and View & 1 & $<1$ & 1 & $<1$ \\
\hline Other Vegetation & 14 & 6 & 15 & 1 \\
\hline Other Natural Subjects & 4 & 2 & 5 & $<1$ \\
\hline Total & $\mathrm{NA}$ & NA & 1965 & 100 \\
\hline
\end{tabular}

1 Total percent of respondents exceeds $100 \%$ since each respondent could have photographed more than two types of natural subjects (i.e., wildflowers \& trees and a lake), photo subjects are not mutually exclusive.

2 Photos that include these subjects may also include human subjects as well, and are not natural subject only photos. Thus, there were 1965 photos that included natural subjects; some of these photos may have included human subjects such as hikers or buildings, for example. 
Table C-2. Count totals and percentages of photos that include human-made subjects $(\mathrm{n}=254$ respondents).

\begin{tabular}{|c|c|c|c|c|}
\hline Human-made subject & $\begin{array}{c}\text { Number of } \\
\text { people who took } \\
\text { a photo of this } \\
\text { subject }\end{array}$ & $\begin{array}{c}\text { Percent of all } \\
\text { people who took } \\
\text { a photo of this } \\
\text { subject }^{1}\end{array}$ & $\begin{array}{l}\text { Number of } \\
\text { photos that } \\
\text { include this } \\
\text { subject }^{2} \\
\end{array}$ & $\begin{array}{c}\text { Percent of all } \\
\text { natural subject } \\
\text { photographs }\end{array}$ \\
\hline People & 91 & 36 & 154 & 23 \\
\hline Trail & 91 & 36 & 126 & 18 \\
\hline Trail Markers/Signs & 43 & 17 & 54 & 8 \\
\hline Campsite & 40 & 16 & 57 & 8 \\
\hline Horse Droppings/Horses & 33 & 13 & 35 & 5 \\
\hline Park Service Buildings & 30 & 12 & 34 & 5 \\
\hline Bridge & 30 & 12 & 34 & 5 \\
\hline People and Trail & 19 & 7 & 21 & 3 \\
\hline Trash & 14 & 6 & 15 & 2 \\
\hline Fishing & 12 & 5 & 14 & 2 \\
\hline People and Campsite & 12 & 5 & 15 & 2 \\
\hline City/City Buildings & 11 & 4 & 12 & 2 \\
\hline Historic Buildings & 10 & 4 & 11 & 2 \\
\hline Erosion/Trampled Vegetation & 10 & 4 & 11 & 2 \\
\hline People and Bridge & 10 & 4 & 10 & 1 \\
\hline Tree Carvings & 9 & 4 & 9 & 1 \\
\hline Roads/Cars/Traffic/Bus & 7 & 3 & 7 & 1 \\
\hline $\begin{array}{l}\text { Alluvial Fan/Dam } \\
\text { Break/Flood }\end{array}$ & 7 & 3 & 7 & 1 \\
\hline Bear Box & 6 & 2 & 6 & 1 \\
\hline Fence/Restoration Area & 5 & 2 & 5 & 1 \\
\hline Climbing & 3 & 1 & 5 & 1 \\
\hline People and Trail Marker & 3 & 1 & 3 & $<1$ \\
\hline Trail and Trail Marker & 3 & 1 & 3 & $<1$ \\
\hline People and Horses/Llamas & 3 & 1 & 3 & $<1$ \\
\hline Bridge and Trail & 2 & 1 & 2 & $<1$ \\
\hline People and Park Service Bldg. & 2 & 1 & 2 & $<1$ \\
\hline Feeding Wildlife & 1 & $<1$ & 1 & $<1$ \\
\hline Campsite and Sign & 1 & $<1$ & 1 & $<1$ \\
\hline Historic Building and People & 1 & $<1$ & 1 & $<1$ \\
\hline Alluvial Fan and Trail Marker & 1 & $<1$ & 1 & $<1$ \\
\hline Other human-made subjects & 19 & 7 & 23 & 3 \\
\hline Total & NA & NA & 682 & 100 \\
\hline
\end{tabular}

1 Total percent of respondents exceeds $100 \%$ since each respondent could have photographed more than two types of human-made subjects (i.e., bridge, trail \& bear box), photo subjects are not mutually exclusive.

2 Photos that include these subjects may also include natural subjects as well, and are not human or human-made subject only photos. Thus, there were 682 photos that included human or human-made subjects; some of these photos may have included natural subjects such as a mountain, for example. 
Table C-3. Count totals and percentages of nature-made sounds ( $\mathrm{n}=254$ respondents).

\begin{tabular}{|c|c|c|c|c|}
\hline Nature sound & $\begin{array}{l}\text { Number of } \\
\text { people who } \\
\text { reported } \\
\text { hearing the } \\
\text { sound }\end{array}$ & $\begin{array}{l}\text { Percent of all } \\
\text { people who } \\
\text { reported } \\
\text { hearing the } \\
\text { sound }^{1}\end{array}$ & $\begin{array}{c}\text { Number of } \\
\text { actual reports } \\
\text { of hearing the } \\
\text { sound }^{2}\end{array}$ & $\begin{array}{c}\text { Percent of all } \\
\text { nature-made } \\
\text { sounds reported }\end{array}$ \\
\hline Water & 185 & 73 & 479 & 28 \\
\hline Birds and water & 113 & 44 & 240 & 14 \\
\hline Wind & 109 & 43 & 235 & 14 \\
\hline Birds & 100 & 39 & 176 & 10 \\
\hline Quiet or silence & 73 & 29 & 134 & 8 \\
\hline Wind and birds & 69 & 27 & 94 & 5 \\
\hline Wind and water & 62 & 24 & 98 & 6 \\
\hline Wildlife other than birds & 29 & 11 & 45 & 3 \\
\hline Insects & 26 & 10 & 35 & 2 \\
\hline Birds and wildlife & 25 & 10 & 33 & 2 \\
\hline Birds and insects & 23 & 9 & 35 & 2 \\
\hline Water and insects & 13 & 5 & 17 & 1 \\
\hline Wind and insects & 13 & 5 & 18 & 1 \\
\hline Water and wildlife & 11 & 4 & 12 & 1 \\
\hline Wind and wildlife & 10 & 4 & 13 & 1 \\
\hline Rain & 9 & 4 & 10 & 1 \\
\hline Thunder and rain & 6 & 2 & 8 & $<1$ \\
\hline Water and thunder & 6 & 2 & 7 & $<1$ \\
\hline Thunder & 5 & 2 & 5 & $<1$ \\
\hline Wind and thunder & 5 & 2 & 8 & $<1$ \\
\hline Rain and water & 5 & 2 & 8 & $<1$ \\
\hline Other nature sounds & 8 & 3 & 10 & 1 \\
\hline Total & NA & NA & 1710 & 100 \\
\hline
\end{tabular}

1 Total percent of respondents exceeds $100 \%$ since each respondent could have reported hearing more than one or two types of nature-made sound (i.e., thunder, rain and wind) sound reports are not mutually exclusive.

2 Natural sounds reported by respondents may have included human sounds as well, thus, these are not natural sound reports only. There were 1710 sound reports of natural sounds; some of these sounds may have been heard in combination with an airplane, for example. 
Table C-4. Count totals and percentages of human-made sounds ( $\mathrm{n}=254$ respondents).

\begin{tabular}{|c|c|c|c|c|}
\hline Human-made sound & $\begin{array}{l}\text { Number of } \\
\text { people who } \\
\text { reported } \\
\text { hearing the } \\
\text { sound }\end{array}$ & $\begin{array}{l}\text { Percent of all } \\
\text { people who } \\
\text { reported } \\
\text { hearing the } \\
\text { sound }^{1}\end{array}$ & $\begin{array}{c}\text { Number of } \\
\text { actual reports } \\
\text { of hearing the } \\
\text { sound }\end{array}$ & $\begin{array}{l}\text { Percent of all } \\
\text { human-made } \\
\text { sounds } \\
\text { reported }\end{array}$ \\
\hline Voices of Other Hikers & 89 & 35 & 154 & 36 \\
\hline Airplanes & 52 & 20 & 73 & 17 \\
\hline Cars & 46 & 18 & 69 & 16 \\
\hline Voices \& Cars & 21 & 8 & 28 & 6 \\
\hline Voices of Respondent & 14 & 6 & 16 & 4 \\
\hline Children & 13 & 5 & 18 & 4 \\
\hline Voices \& Airplanes & 12 & 5 & 15 & 3 \\
\hline Breathing & 11 & 4 & 12 & 3 \\
\hline Footsteps of respondent & 8 & 3 & 8 & 2 \\
\hline Airplanes \& Cars & 8 & 3 & 10 & 2 \\
\hline Footsteps of other hikers & 4 & 2 & 4 & 1 \\
\hline $\begin{array}{l}\text { Voices \& footsteps of other } \\
\text { hikers }\end{array}$ & 5 & 2 & 6 & 1 \\
\hline Construction/Building & 5 & 2 & 5 & 1 \\
\hline Heartbeat & 3 & 1 & 4 & 1 \\
\hline Motorcycles & 3 & 1 & 3 & 1 \\
\hline Horses \& People & 2 & 1 & 2 & $<1$ \\
\hline Horses & 1 & $<1$ & 1 & $<1$ \\
\hline $\begin{array}{l}\text { Voices \& Footsteps of } \\
\text { respondent }\end{array}$ & 1 & $<1$ & 1 & $<1$ \\
\hline Other Human-Made Sounds & 9 & 4 & 9 & 2 \\
\hline Total & NA & NA & 438 & 100 \\
\hline
\end{tabular}

1 Total percent of respondents exceeds $100 \%$ since each respondent could have reported hearing more than one or two types of human-made sound (i.e., horses \& people and airplanes), sound reports are not mutually exclusive.

2 Human sounds reported by respondents may have included nature sounds as well, thus, these are not human sound reports only. There were 438 sound reports of human sounds; some of these sounds may have been heard in combination with birds or wind, for example. 
Table C-5. Place names in RMNP of photo subjects and special places. ${ }^{1}$

\begin{tabular}{|c|c|c|}
\hline Important Place Names: & & $\begin{array}{c}\text { Total Count and } \\
\text { (Aggregate Percent) }\end{array}$ \\
\hline Lakes or Ponds & (352 total occurrences) & $(39 \%)$ \\
\hline Fern Lake & & 22 \\
\hline Cub Lake & & 19 \\
\hline Odessa Lake & & 17 \\
\hline Mills Lake & & 16 \\
\hline Dream Lake & & 15 \\
\hline Chasm Lake & & 15 \\
\hline Lion Lakes & & 13 \\
\hline Bear Lake & & 13 \\
\hline Sky Pond & & 13 \\
\hline Loch Lake & & 13 \\
\hline Thunder Lake & & 12 \\
\hline Bierstadt Lake & & 11 \\
\hline Emerald Lake & & 10 \\
\hline Lawn Lake & & 10 \\
\hline Black Lake & & 9 \\
\hline Ypsilon Lake & & 8 \\
\hline Lost Lake & & 7 \\
\hline Timber Lake & & 7 \\
\hline Ouzel Lake & & 7 \\
\hline Bluebird Lake & & 7 \\
\hline Spruce Lake & & 7 \\
\hline Grand Lake & & 6 \\
\hline Glass Lake & & 6 \\
\hline Sandbeach Lake & & 6 \\
\hline Haynoch Lake & & 6 \\
\hline Nymph Lake & & 6 \\
\hline Peacock Lake & & 5 \\
\hline Hiayaha Lake & & 5 \\
\hline Husted Lake & & 4 \\
\hline Julian Lake & & 4 \\
\hline Lone Pine Lake & & 4 \\
\hline Chickadee Pond & & 3 \\
\hline Chipmunk Lake & & 3 \\
\hline Spirit Lake & & 3 \\
\hline Verna Lake & & 3 \\
\hline Green Lake & & 2 \\
\hline Irene Lake & & 2 \\
\hline Lily Lake & & 2 \\
\hline Many Winds & & 2 \\
\hline Shadow Lake & & 2 \\
\hline
\end{tabular}

1 Place names were given by respondents in both photo-log booklet photo subject descriptions and in follow-up survey as special places that were not visited on this trip. 
Table C-5. (Continued - 2) Place names in RMNP

\begin{tabular}{|c|c|c|}
\hline Lakes or Ponds & (continued) & $\# \quad(\%)$ \\
\hline Chiquita Lake & & 2 \\
\hline Mirror Lake & & 2 \\
\hline Spectacle Lake & & 2 \\
\hline Sprague Lake & & 2 \\
\hline Chickory Lake & & 1 \\
\hline Copeland Lake & & 1 \\
\hline Estes Lake & & 1 \\
\hline Finch Lake & & 1 \\
\hline Lost Pine Lake & & 1 \\
\hline Louise Lake & & 1 \\
\hline Mary's Lake & & 1 \\
\hline Mirror Pond & & 1 \\
\hline Nokoni Lake & & 1 \\
\hline Sheep Lake & & 1 \\
\hline Snowbank Lake & & 1 \\
\hline Gem Lake & & 1 \\
\hline Loomis Lake & & 1 \\
\hline Andrew's Tarn & & 1 \\
\hline Parika Lake & & 1 \\
\hline Hutchenson Lakes & & 1 \\
\hline Frozen Lake & & 1 \\
\hline Gorge Lakes & & 1 \\
\hline Geological Features & (203 total occurrences) & $(22 \%)$ \\
\hline Long's Peak & & 81 \\
\hline Hallet Peak & & 19 \\
\hline Keyhole & & 11 \\
\hline Mummy Range & & 10 \\
\hline Estes Cone & & 8 \\
\hline Alice & & 7 \\
\hline Flattop Mountain & & 7 \\
\hline Meeker & & 6 \\
\hline Ypsilon Mountain & & 6 \\
\hline Never Summer Mountains & & 6 \\
\hline Twin Sisters & & 6 \\
\hline Andrew's Glacier & & 5 \\
\hline Ida & & 5 \\
\hline Spearhead & & 5 \\
\hline Baldi & & 4 \\
\hline Specimen Mountain & & 4 \\
\hline Little Matterhorn & & 3 \\
\hline Lumpy Ridge & & 3 \\
\hline Notchtop Mountain & & 3 \\
\hline Ptarmigan Mountain & & 3 \\
\hline Tyndall Glacier & & 3 \\
\hline Milner Pass & & 3 \\
\hline Arrowhead & & 2 \\
\hline
\end{tabular}


Table C 5. (Continued - 3) Place names in RMNP

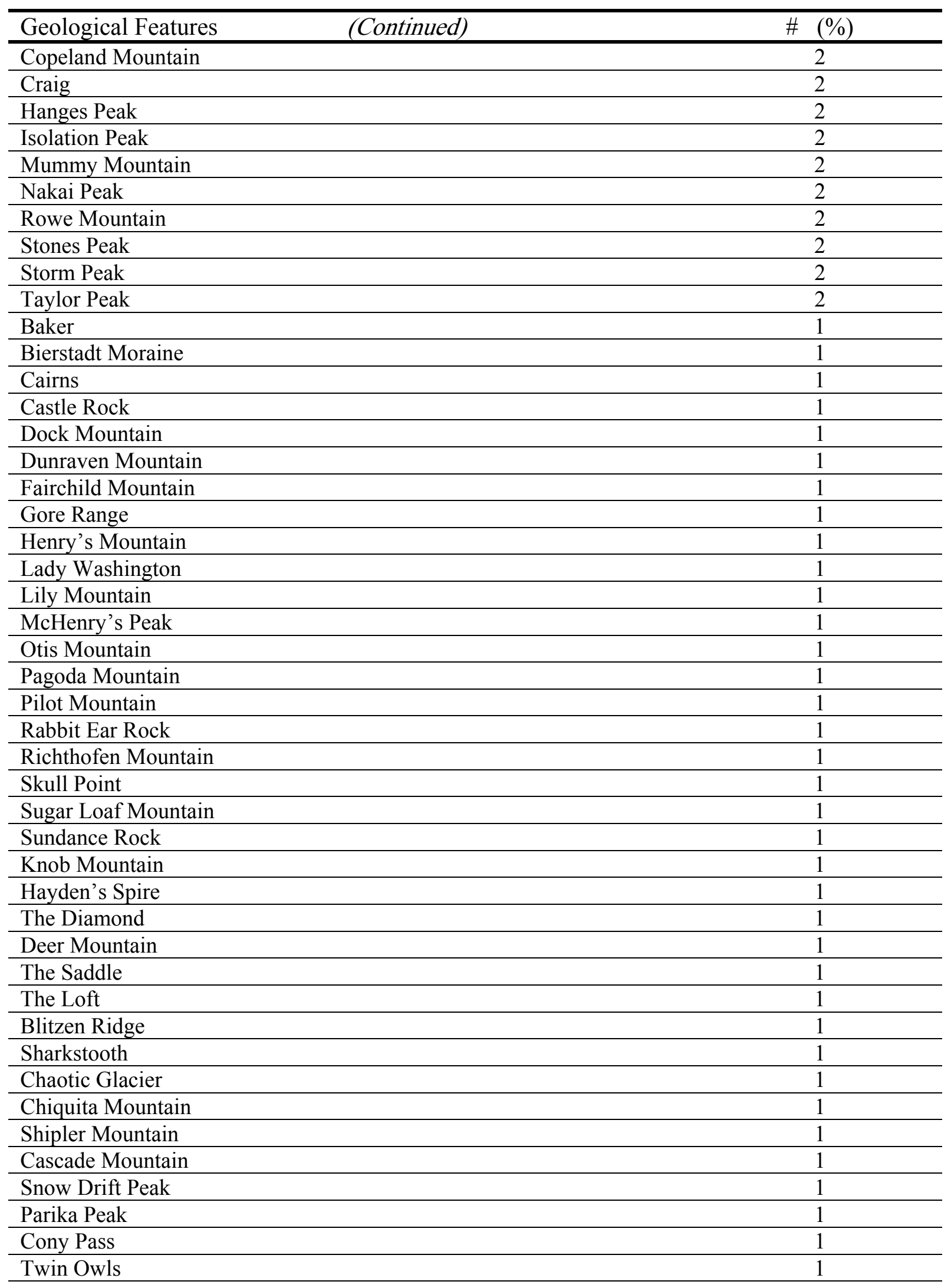


Table C-5. (Continued - 4) Place names in RMNP

\begin{tabular}{|c|c|c|}
\hline Waterfalls & (131 total occurrences) & $(14 \%)$ \\
\hline Alberta Falls & & 21 \\
\hline Ouzel Falls & & 18 \\
\hline Copeland Falls & & 16 \\
\hline The Pool & & 15 \\
\hline Calypso Falls/Cascades & & 13 \\
\hline Adams Falls & & 9 \\
\hline Granite Falls & & 8 \\
\hline Cascade Falls & & 8 \\
\hline Fern Falls & & 6 \\
\hline Ribbon Falls & & 3 \\
\hline Timberline Falls & & 3 \\
\hline Bridal Veil Falls & & 2 \\
\hline Beaver Creek Falls & & 1 \\
\hline Chasm Falls & & 1 \\
\hline Fairy Falls & & 1 \\
\hline Grace Falls & & 1 \\
\hline Little Yellowstone Falls & & 1 \\
\hline Rivers or Streams & (76 total occurrences) & $(8 \%)$ \\
\hline Big Thompson River & & 16 \\
\hline Onahu Creek & & 12 \\
\hline Colorado River & & 10 \\
\hline St. Vrain Creek & & 6 \\
\hline Ouzel Creek & & 4 \\
\hline Roaring River & & 4 \\
\hline Timber Creek & & 4 \\
\hline Tonahutu Creek & & 3 \\
\hline Poudre River & & 3 \\
\hline Fall River & & 2 \\
\hline North Inlet Creek & & 2 \\
\hline Boulder Brook & & 2 \\
\hline North Inlet River & & 2 \\
\hline Spruce Creek & & 1 \\
\hline Fern River & & 1 \\
\hline Cub Stream & & 1 \\
\hline Andrew Creek & & 1 \\
\hline Trails or Areas & (87 total occurrences) & $(10 \%)$ \\
\hline Bear Lake Trail & & 9 \\
\hline Glacier Gorge & & 9 \\
\hline Moraine Park & & 8 \\
\hline Wild Basin & & 6 \\
\hline Loch Vale & & 5 \\
\hline North Fork Trail & & 3 \\
\hline Lawn Lake Trail & & 3 \\
\hline Odessa Lake Region & & 2 \\
\hline Paradise Park & & 2 \\
\hline
\end{tabular}


Table C-5. (Continued - 5) Place names in RMNP

\begin{tabular}{|c|c|c|}
\hline Trails or Areas & (continued) & $\# \quad(\%)$ \\
\hline West Side of Park & & 2 \\
\hline Hallett Peak Area & & 2 \\
\hline Colorado River Trail & & 2 \\
\hline Timber Lake Trail & & 2 \\
\hline Longs Peak Trail & & 2 \\
\hline Grand Ditch & & 2 \\
\hline Ouzel Lake Burn Area & & 2 \\
\hline Spruce Lake Trail & & 2 \\
\hline Cub Lake Trail & & 2 \\
\hline Chasm Lake Trail & & 2 \\
\hline Bowen-Baker Trail & & 1 \\
\hline Forest Canyon Pass Trail & & 1 \\
\hline Cow Creek Trail & & 1 \\
\hline Glacier Basin & & 1 \\
\hline Flattop \& Notchtop Area & & 1 \\
\hline Andrews Tarn Area & & 1 \\
\hline Hayden Gorge & & 1 \\
\hline Ute Trail & & 1 \\
\hline Mummy Mountain Area & & 1 \\
\hline Stoneman Pass Area & & 1 \\
\hline North Inlet Trail & & 1 \\
\hline Onahu Creek Trail & & 1 \\
\hline Coney Creek Trail & & 1 \\
\hline Twin Sisters Trail & & 1 \\
\hline Dream Lake Trail & & 1 \\
\hline Lake Hiayaha Trail & & 1 \\
\hline Poudre Lake Trail & & 1 \\
\hline Deer Mountain Trail & & 1 \\
\hline Adams Falls Trail & & 1 \\
\hline Ypsilon Lake Trail & & 1 \\
\hline Roads & (17 total occurrences) & $(2 \%)$ \\
\hline Fall River Road & & 9 \\
\hline Trail Ridge Road & & 8 \\
\hline Valleys or Meadows & (11 total occurrences) & $(1 \%)$ \\
\hline Kawuneeche Valley & & 2 \\
\hline Endovalley & & 2 \\
\hline Big Meadows & & 1 \\
\hline Ute Meadows & & 1 \\
\hline Tonohutu Meadows & & 1 \\
\hline Colorado River Valley & & 1 \\
\hline East Inlet Valley & & 1 \\
\hline Andrew's Meadow & & 1 \\
\hline Hague Creek Valley & & 1 \\
\hline
\end{tabular}


Table C-5. (Continued - 6) Place names in RMNP \# (\%)

\begin{tabular}{|c|c|}
\hline (19 total occurrences) & $(3 \%)$ \\
\hline Kettle Tarn Campsite & 3 \\
\hline Forest Canyon Overlook & 3 \\
\hline Alpine Visitors Center & 2 \\
\hline Lodge in Hollowell Park & 2 \\
\hline Eugenia Mine & 2 \\
\hline July Campsite & 2 \\
\hline Shipler Cabin & 2 \\
\hline Lost Meadow Group Site & 2 \\
\hline Sandbeach Lake Campsite & 1 \\
\hline Jackstraw Campsite & 1 \\
\hline Bighand Viewing Area & 1 \\
\hline Agnes Wolcotville/Sortland Shelter & 1 \\
\hline (13 total occurrences) & $(1 \%)$ \\
\hline Estes Park & 7 \\
\hline Boulderfield & 2 \\
\hline Flat Rock & 2 \\
\hline Alluvial fan & 2 \\
\hline
\end{tabular}




\section{Appendix D}

\section{Follow-up Survey Results}

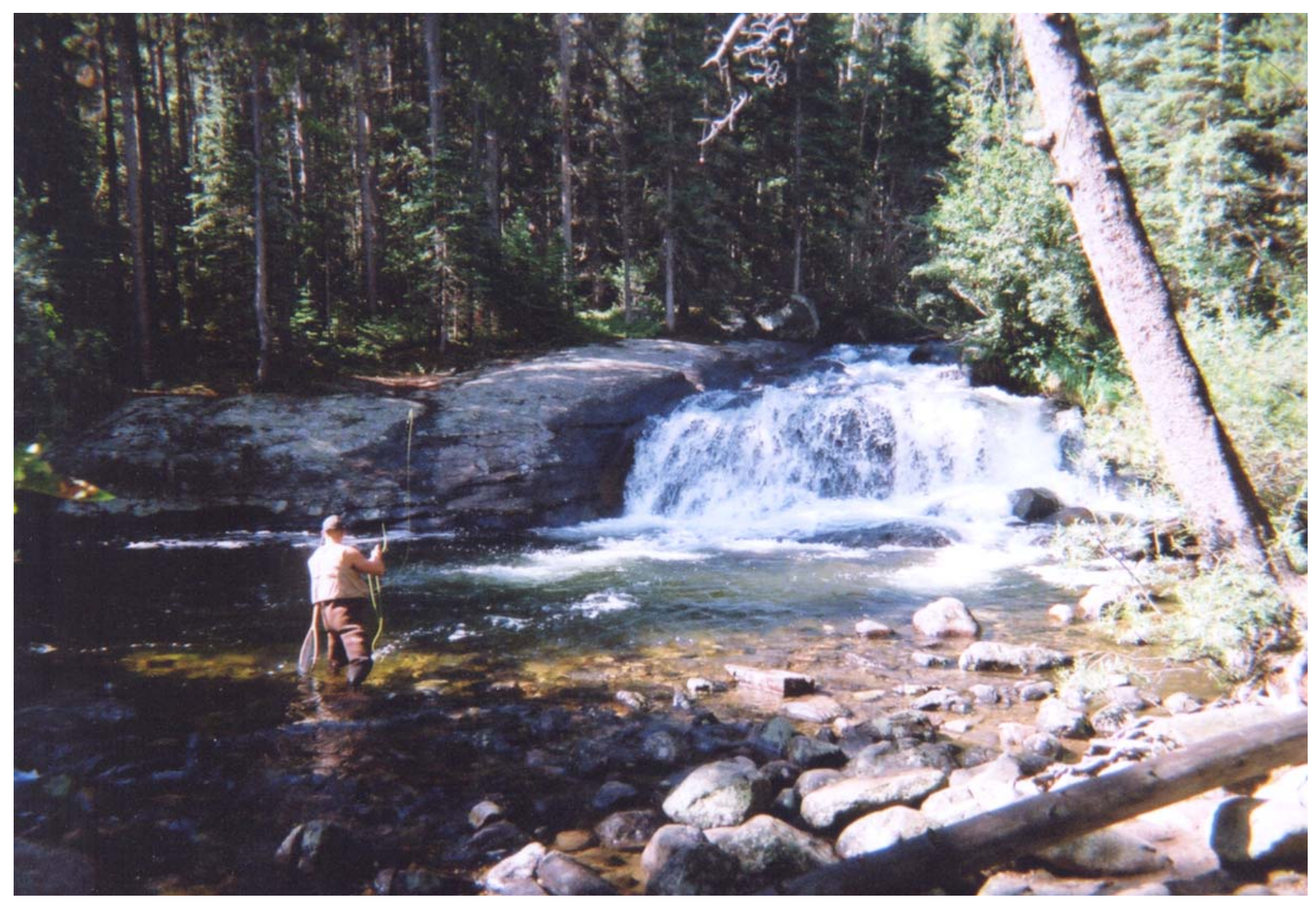


Table D-1. Most important photographed place to wilderness experience $(n=125)^{1}$

\begin{tabular}{lcc}
\hline Subject & $\mathrm{n}$ & $\%$ \\
\hline Lake/Pond & 28 & 22 \\
\hline View/Scenery & 15 & 12 \\
\hline Wildlife & 11 & 9 \\
\hline Lake and Mountain & 9 & 7 \\
\hline Waterfall & 9 & 6 \\
\hline Mountain/Glacier & 8 & 6 \\
\hline Summit of Mountain & 8 & 5 \\
\hline Stream & 6 & 4 \\
\hline Alpine Tundra/Above tree-line & 5 & 3 \\
\hline Meadow/Valley & 4 & 3 \\
\hline Trail/Trailhead & 4 & 3 \\
\hline People & 4 & 2 \\
\hline Forest Fire and Re-growth & 3 & 2 \\
\hline Signs & 3 & 2 \\
\hline Rocks & 2 & 2 \\
\hline Horse droppings & 2 & 2 \\
\hline Park Service Buildings/Campsite & 2 & 100 \\
\hline Fishing/Climbing & 2 & \\
\hline Total & 125 & 2 \\
\hline
\end{tabular}

$1 \mathrm{n}$ represents the number of responses to this question 
Table D-2. Important Wilderness Experience Themes with Sub-Categories $(n=322)^{1}$

\begin{tabular}{|c|c|c|}
\hline Themes $^{2}$ & $(\%)$ & $\mathrm{n}$ \\
\hline AESTHETICS: & $(25)$ & 82 \\
\hline Beauty & & 26 \\
\hline Scenery & & 12 \\
\hline Unspoiled nature & & 12 \\
\hline Wildlife & & 11 \\
\hline Appreciation of nature & & 9 \\
\hline Smells and sounds & & 8 \\
\hline Protection of nature & & 4 \\
\hline PHYSICAL ESCAPE: & $(17)$ & 55 \\
\hline Away from everyday life/ Away from it all & & 16 \\
\hline Getting away from people & & 10 \\
\hline Getting away from the city & & 9 \\
\hline Away from noise / pollution / traffic & & 8 \\
\hline Getting away from civilization & & 6 \\
\hline Away from work & & 5 \\
\hline Easy access & & 1 \\
\hline SOLITUDE: & $(14)$ & 46 \\
\hline Peace & & 18 \\
\hline No crowds / Other humans & & 10 \\
\hline Relaxing & & 8 \\
\hline Solitude & & 7 \\
\hline Quiet & & 3 \\
\hline THERAPEUTIC (feeling): & $(8)$ & 27 \\
\hline Refreshing / Invigorating / Rejuvenating & & 11 \\
\hline Peace of mind & & 9 \\
\hline Peak experience & & 3 \\
\hline Feeling alive and happy & & 2 \\
\hline Inspiring & & 2 \\
\hline BACK TO BASICS: & (7) & 21 \\
\hline Connection with nature & & 6 \\
\hline Like being an explorer & & 5 \\
\hline Home & & 4 \\
\hline Visiting another place / World & & 3 \\
\hline Getting back to basics / What's important & & 3 \\
\hline GOD: & $(6)$ & 20 \\
\hline Experiencing God / Feeling close to God & & 9 \\
\hline God's natural beauty & & 5 \\
\hline God's creation & & 4 \\
\hline Nature as a church & & 2 \\
\hline
\end{tabular}


Table D-2 (cont.) Important Wilderness Experience Themes with Sub-Categories

\begin{tabular}{|c|c|c|}
\hline EXERCISE / HEALTH: & $(6 \%)$ & 19 \\
\hline Specific activities & & 10 \\
\hline Getting exercise & & 8 \\
\hline Fresh air & & 1 \\
\hline GOAL ATTAINMENT: & (6) & 19 \\
\hline Adventure & & 6 \\
\hline Self-reliance & & 5 \\
\hline Challenge & & 5 \\
\hline Sense of accomplishment & & 3 \\
\hline INTROSPECTION (thinking): & (4) & 13 \\
\hline Thinking / Reflecting on life & & 8 \\
\hline Gaining fresh perspective on life & & 3 \\
\hline Memories & & 1 \\
\hline Tradition & & 1 \\
\hline FEELING OF AWE: & (3) & 11 \\
\hline Open expanse / Vastness & & 5 \\
\hline Wonder at nature / Marvel & & 3 \\
\hline Feeling very small & & 2 \\
\hline Feeling of awe & & 1 \\
\hline SOCIALIZING: & (3) & 9 \\
\hline Being with family & & 6 \\
\hline Being with friends & & 3 \\
\hline
\end{tabular}

$1 \mathrm{n}$ represents the number of responses to this question; respondents could list more than one experience

2 Themes "emerged" from content analysis of Question 5 
Table D-3. Follow-up survey demographic variables $(n=140)^{1}$

\begin{tabular}{|c|c|c|}
\hline Variable & $\mathrm{n}$ & $\%$ \\
\hline $\begin{array}{l}\text { GENDER: } \\
\text { Male } \\
\text { Female }\end{array}$ & $\begin{array}{l}82 \\
56\end{array}$ & $\begin{array}{l}59 \\
41\end{array}$ \\
\hline $\begin{array}{l}\text { AGE: } \\
15-25 \\
26-35 \\
36-45 \\
46-55 \\
56-65 \\
66-75\end{array}$ & $\begin{array}{c}9 \\
28 \\
28 \\
37 \\
26 \\
11\end{array}$ & $\begin{array}{c}6 \\
20 \\
20 \\
27 \\
19 \\
8\end{array}$ \\
\hline $\begin{array}{l}\text { CHILDHOOD RESIDENCE: } \\
\text { Farm or ranch } \\
\text { Rural or small town }(<1,000 \text { people }) \\
\text { Town }(1,000 \text { to } 5,000 \text { people }) \\
\text { Small city }(5,000 \text { to } 50,000 \text { people }) \\
\text { Medium city ( } 50,000 \text { to } 1 \text { million people }) \\
\text { Metropolitan area }\end{array}$ & $\begin{array}{l}18 \\
10 \\
18 \\
38 \\
37 \\
18\end{array}$ & $\begin{array}{c}13 \\
7 \\
13 \\
27 \\
27 \\
13\end{array}$ \\
\hline $\begin{array}{l}\text { EDUCATION: } \\
<\text { High school } \\
\text { High school } \\
\text { College } \\
\text { Graduate or Professional }\end{array}$ & $\begin{array}{c}0 \\
13 \\
59 \\
67\end{array}$ & $\begin{array}{l}0 \\
9 \\
43 \\
48\end{array}$ \\
\hline $\begin{array}{l}\text { ARE YOU STILL A STUDENT: } \\
\text { Yes } \\
\text { No }\end{array}$ & $\begin{array}{c}23 \\
114 \\
\end{array}$ & $\begin{array}{l}17 \\
83 \\
\end{array}$ \\
\hline $\begin{array}{l}\text { INCOME: } \\
<\$ 5,000 \\
\$ 5,000-\$ 9,999 \\
\$ 10,000-\$ 14,999 \\
\$ 15,000-\$ 19,999 \\
\$ 20,000-\$ 24,999 \\
\$ 25,000-\$ 34,999 \\
\$ 35,000-\$ 49,999 \\
\$ 50,000-\$ 74,999 \\
\$ 75,000-\$ 100,000 \\
>\$ 100,000\end{array}$ & $\begin{array}{c}1 \\
2 \\
2 \\
2 \\
7 \\
9 \\
17 \\
33 \\
32 \\
31\end{array}$ & $\begin{array}{c}1 \\
1 \\
1 \\
1 \\
5 \\
7 \\
13 \\
24 \\
24 \\
23\end{array}$ \\
\hline $\begin{array}{l}\text { PEOPLE CONTRIBUTING TO INCOME: } \\
\text { One person } \\
\text { Two people } \\
\text { Three people }\end{array}$ & $\begin{array}{l}67 \\
68 \\
2\end{array}$ & $\begin{array}{c}49 \\
50 \\
1\end{array}$ \\
\hline
\end{tabular}

$1 \mathrm{n}$ represents the number of returned surveys. 


\section{Figure D-1. How does this sound alter your wilderness experience?}

\section{Scale points were collapsed into 1-4="detracts", 5-6="neutral", and 7-10="enhances"}

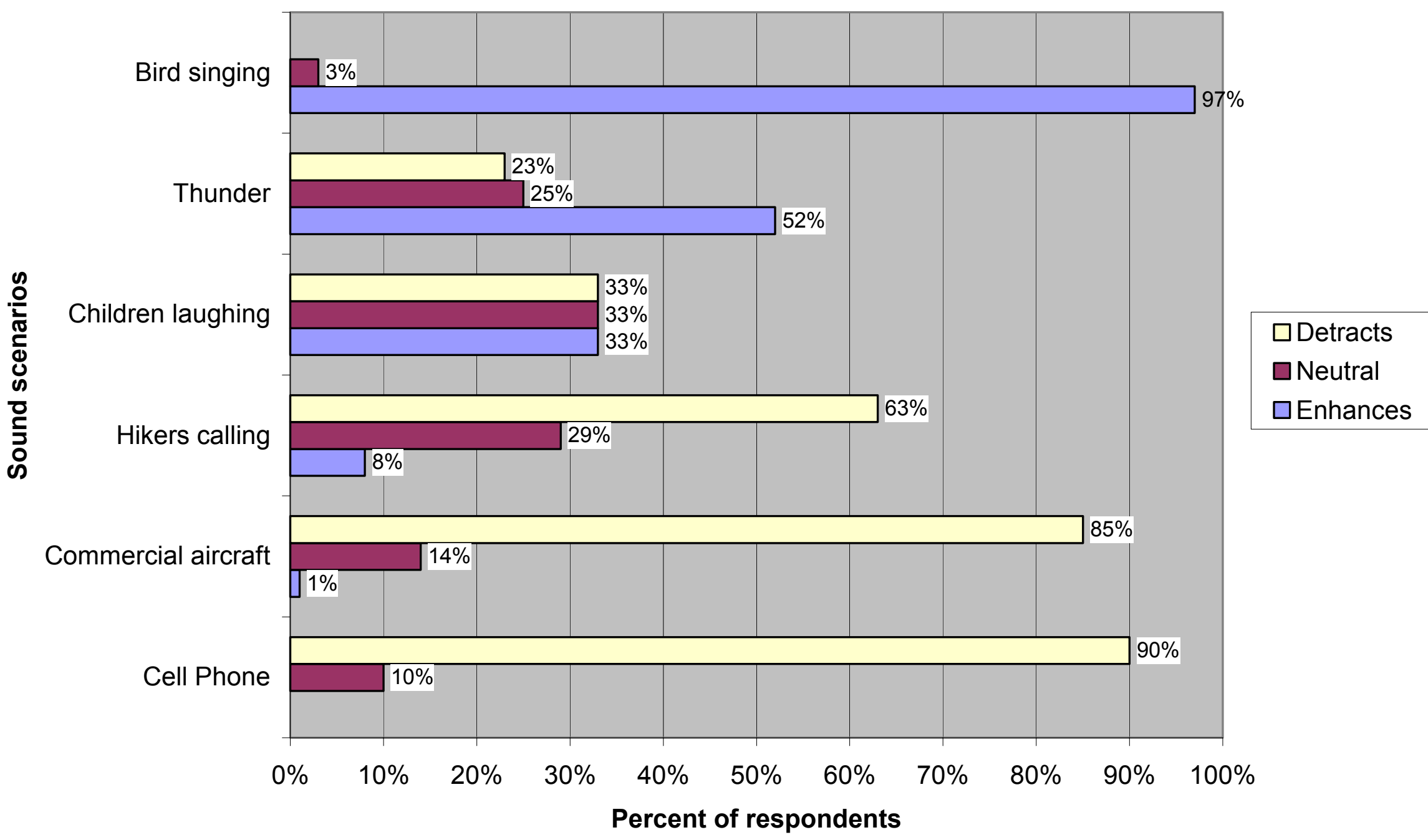


Figure D-2. How does this sight alter your wilderness experience?

Scale points were collapsed into 1-4="detracts", 5-6="neutral", and 7-10="enhances"

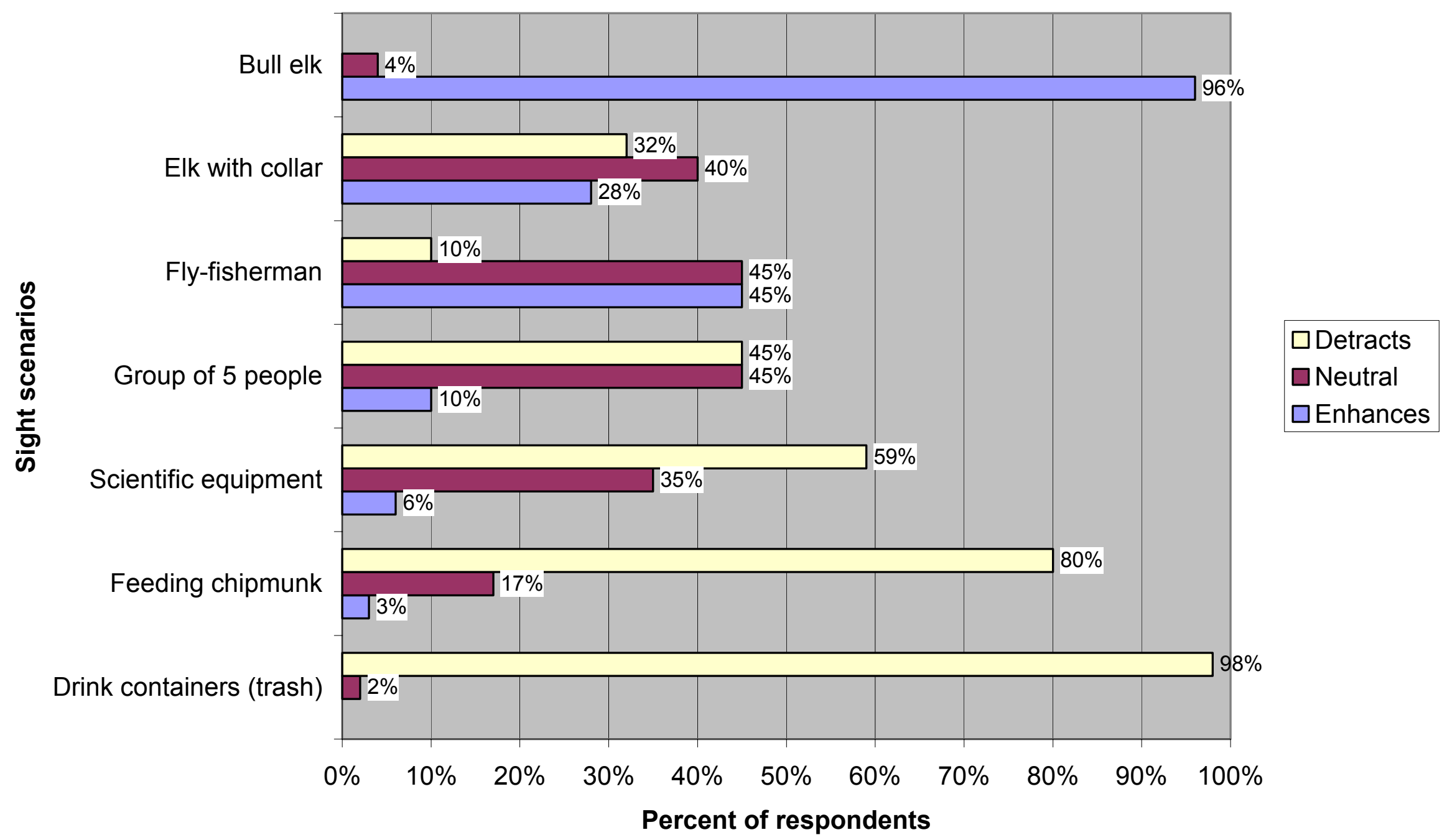

